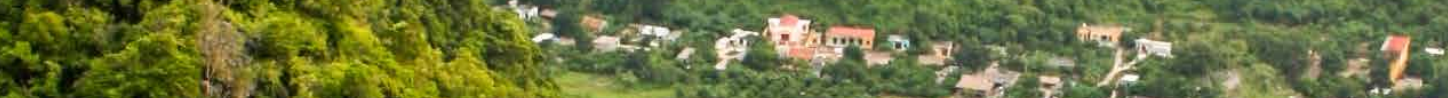

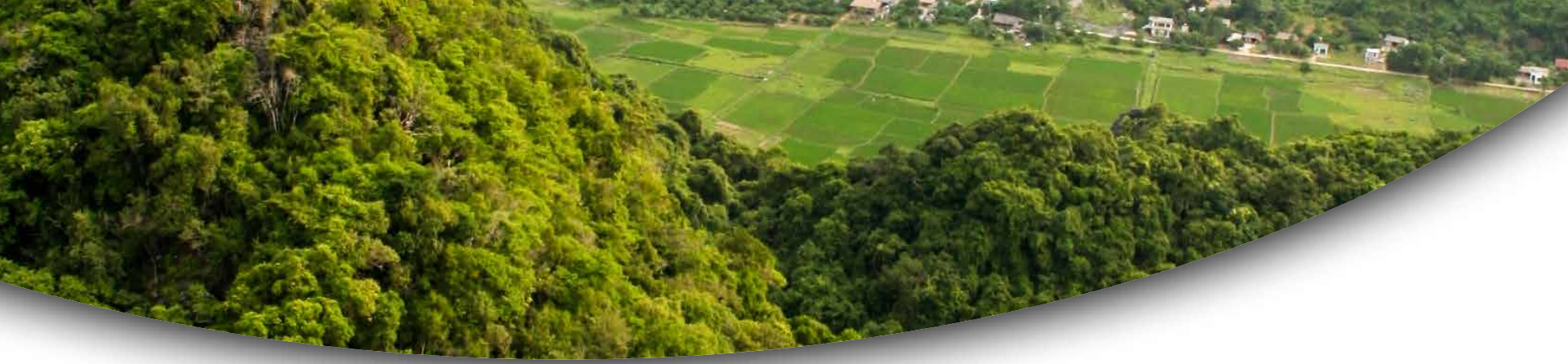

Kết quả thực hiện Chiến lược phát triển Lâm nghiệp Việt Nam giai đoạn 2006-2020 và đề xuất nội dung Chiến lược phát triển Lâm nghiệp Việt Nam giai đoạn 2021-2030, tầm nhìn đến năm 2050

Triệu Văn Hùng

Phạm Thu Thủy

Đào Thị Linh Chi
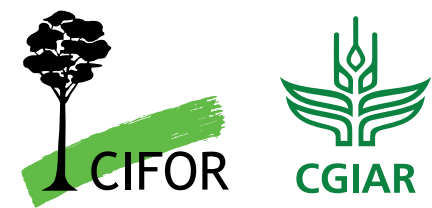



\section{Kết quả thực hiện Chiến lược phát triển Lâm nghiệp Việt Nam giai đoạn 2006-2020 và đề xuất nội dung Chiến lược phát triển Lâm nghiệp Việt Nam giai đoạn 2021-2030, tầm nhìn đến năm 2050}

Triệu Văn Hùng

Tưvấn độc lập

Phạm Thu Thủy

CIFOR

Đào Thị Linh Chi

CIFOR 
Báo cáo chuyên đề 209

C 2020 Tổ chức Nghiên cứu Lâm nghiệp Quốc tế (CIFOR)

Nội dung trong ấn phẩm này được cấp quyền bởi Giấy phép bản quyền Ghi nhận công của tác giả - Phi thương mại, không chỉnh sửa, thay đổi hay phát triển - Không phát sinh 4.0. http://creativecommons.org/ licenses/by-nc-nd/4.0/

ISBN 978-602-387-144-5

DOI: $10.17528 /$ cifor/007795

Triệu VH, Phạm TT và Đào TLC. 2020. Kết quả thực hiện Chiến lược phát triển Lâm nghiệp Việt Nam giai đoạn 2006-2020 và đề xuất nội dung Chiến lược phát triển Lâm nghiệp Việt Nam giai đoạn 2021-2030, tầm nhìn đến năm 2050. Báo cáo chuyên đề 209. Bogor, Indonesia: CIFOR.

Ảnh được chụp bởi Terry Sunderland/CIFOR.

Cảnh quan miền núi phía Bắc Việt Nam.

\section{CIFOR}

Jl. CIFOR, Situ Gede

Bogor Barat 16115

Indonesia

$\mathrm{T}+62$ (251) 8622-622

$\mathrm{F}+62(251) 8622-100$

E cifor@cgiar.org

\section{cifor.org}

Chúng tôi xin cảm ơn các nhà tài trợ đã hỗ trợ cho nghiên cứu này thông qua việc đóng góp vào quỹ của CGIAR. Xin xem danh sách các nhà tài trợ: http://www.cgiar.org/about-us/our-funders/

Tất cả các quan điểm thể hiện trong ấn phẩm này là của các tác giả. Chúng không nhất thiết đại diện cho quan điểm của CIFOR, các cơ quan chủ quản của tác giả hay của các nhà tài trợ cho ấn phẩm này. 


\section{Mục lục}

Lời cảm ơn

Danh mục từ viết tắt

1 Giới thiệu 1

2 Phương pháp $\quad 2$

3 Thông tin tổng quan - Mục tiêu, định hướng và cách tiếp cận của chiến lược 2006-2020

3.1 Giai đoạn 2006-2010 3

3.2 Giai đoạn 2011-2015 6

3.3 Giai đoạn 2016-2020 7

4 Kết quả thực hiện các mục tiêu trong chiến lược phát triển lâm nghiệp việt nam 2006-2020

4.1 Kinh tế

4.2 Môi trường

4.3 Xã hội

\section{(1)}

5 Kết quả thực hiện các chương trình $\quad 19$

5.1 Chương trình quản lý và phát triển rừng bền vững 19

5.2 Chương trình bảo vệ, bảo tôn đa dạng sinh học và phát triển các dịch vụ môi trường

5.3 Chương trình chế biến gỗ và thương mại lâm sản 25

5.4 Chương trình nghiên cứu, giáo dục, đào tạo và khuyến lâm 27

5.5 Chương trình đổi mới thể chế, chính sách, lập kế hoạch và giám sát ngành 29

6 Kết quả huy động nguồn lực thực hiện chiến lược 33

7 Bài học kinh nghiệm rút ra tù̀ quá trình thực hiện chiến lược phát triển lâm nghiệp 2006-2020 35

8 Đề xuất cho chiến lược phát triển 2021-2030 tầm nhìn 2050

8.1 Tiệm cận với xu thế phát triển lâm nghiệp trên thế giới 37

8.2 Đề xuất của địa phương vê phát triển lâm nghiệp giai đoạn tới 39

8.3 Tiếp cận đa ngành và toàn diện 39

$\begin{array}{ll}\text { Tài liệu tham khảo } & 45\end{array}$

Phụ lục $\quad 48$

Danh mục văn bản chính sách, pháp luật Lâm nghiệp giai đoạn 2006-2020 48 


\section{Danh mục hình, bảng và hộp}

$\begin{array}{llr}\text { Hình } & 3 \\ 1 & \text { Bốn định hướng chiến lược } & 4 \\ 2 & \text { Bảy giải pháp thực hiện chiến lược } & 4 \\ 3 & \text { Năm chương trình mục tiêu trong chiến lược } & 20 \\ 4 & \text { Diễn biến diện tích 3 loại rừng giai đoạn 2006-2019 } & 21 \\ 5 & \text { Diện tích đất lâm nghiệp giai đoạn 2006-2020 } & 21 \\ 6 & \text { Diện tích rừng phân theo chủ quản lý giai đoạn 2006-2019 (ha) } & 21 \\ 7 & \text { Trồng rừng tập trung giai đoạn 2006-2019 } & 22 \\ 8 & \text { Diễn biến diện tích RT 2006-2019 } & 22 \\ 9 & \text { Sản lượng khai thác gỗ RT 2006-2019 } & 24 \\ 10 & \text { Tổng thu DVMTR giai đoạn 2011-2020 } & 26 \\ 11 & \text { Giá trị xuất khẩu lâm sản 2006-2020 } & 32 \\ 12 & \text { Một số mốc xây dựng chính sách lâm nghiệp giai đoạn 2004-2020 } & 39 \\ 13 & \text { Kiến nghị của địa phương vể phát triển lâm nghiệp giai đoạn tới } & 40 \\ 14 & \text { Định hướng quy hoạch phát triển các loại rừng }\end{array}$

\section{Bảng}

1 Mục tiêu kinh tế và kết quả thực hiện 9

2 Nguyên nhân không đạt được các mục tiêu đề ra trong chiến lược 10

3 Kết quả thực hiện theo vùng sinh thái về phát triển ngành chế biến lâm sản 13

4 Mục tiêu và kết quả thực hiện các mục tiêu môi trường 14

5 Kết quả thực hiện về diện tích và tỉ lệ che phủ rừng theo các vùng sinh thái

6 Mục tiêu xã hội và kết quả thực hiện 16

7 Chỉ tiêu và kết quả thực hiện của chương trình quản lí và phát triển rừng bền vững 19

8 Tỷ lệ rừng trông/tổng diện tích rừng giai đoạn 2006-2019 22

9 Kết quả đạt được của Chương trình bảo vệ, bảo tôn đa dạng sinh học và phát triển dịch vụ môi trường rừng 23

10 Số vụ vi phạm Luật bảo vệ và phát triển rừng và diện tích rừng bị hại 24

11 Mục tiêu và kết quả thực hiện của chương trình chế biến gỗ và thương mại lâm sản 26

12 Mục tiêu và kết quả thực hiện của chương trình nghiên cứu, giáo dục, đào tạo và khuyến lâm 27

13 Mục tiêu về thể chế và kết quả đạt được 30

14 Kết quả huy động nguôn lực thực hiện chiến lược 34

15 Nguyên nhân 35

16 Hạn chế, tồn tại trong phát triển lâm nghiệp giai đoạn 2006-2020 của địa phương 36

\section{Hộp}

1 Kết quả Dự án trông mới 5 triệu ha rừng giai đoạn 2006-2010

2 Nguyên nhân chính dẫn đến thách thức trong việc giao đất và giao rừng tại

$\begin{array}{ll}\text { Việt Nam } & 17\end{array}$

3 Thách thức trong việc nâng cao tính hiệu quả của PFES 25

4 Xu thế thế giới tới năm 2030

5 Tình hình phát triển của Việt Nam trong giai đoạn 20 năm trở lại đây 38 


\section{Lời cảm ơn}

Nghiên cứu này là một phần của Nghiên cứu so sánh toàn cầu về REDD+ (www.cifor.org/gcs). Chúng tôi xin gửi lời cảm ơn chân thành tới Cơ quan Phát triển $\mathrm{Na} U y$ (NORAD), Sáng kiến khí hậu toàn cầu (IKI) của Bộ Môi trường, Bảo tôn thiên, Xây dựng và An toàn hạt nhân (BMUB) của Đức, và Chuwong trình Nghiên cứu về rừng, cây, và Nông lâm kết hợp (CRP-FTA) và các nhà tài trợ của CGIAR.

Chúng tôi cũng xin gửi lời cảm ơn các lãnh đạo và chuyên viên thuộc Tổng cục Lâm nghiệp, Bộ Nông nghiệp và phát triển nông thôn, các tổ chức nghiên cứu, các Hiệp hội, các tổ chức quốc tế đã dành thời gian tham gia và hỗ trợ nghiên cứu này.

Chúng tôi xin gửi lời cảm ơn chân thành tới bà Nguyễn Thị Thủy Anh và Nguyễn Thị Vân Anh đã hỗ trợ chúng tôi trong quá trình tiến hành nghiên cứu. 


\section{Danh mục từ viết tắt}

\begin{tabular}{|c|c|}
\hline $\mathrm{BĐKH}$ & Biến đổi khí hậu \\
\hline BVR & Bảo vệ rừng \\
\hline BV\&PTR & Bảo vệ và phát triển rừng \\
\hline CBG & Chế biến gỗ \\
\hline CBLS & Chế biến lâm sản \\
\hline CCR & Chứng chỉ rừng \\
\hline $\mathrm{CDM}$ & Cơ chế phát triển sạch \\
\hline CITES & Công ước về thương mại quốc tế các loài động, thực vật hoang dã nguy cấp \\
\hline DLST & Du lịch sinh thái \\
\hline $\mathrm{DN}$ & Doanh nhiệp \\
\hline DVMTR & Dịch vụ môi trường rừng \\
\hline DLST & Du lịch sinh thái \\
\hline ĐDSH & Đa dạng sinh học \\
\hline FDI & Đâu tư trực tiếp nước ngoài \\
\hline GDP & Tổng sản phẩm quốc nội \\
\hline $\mathrm{KHCN}$ & Khoa học công nghệ \\
\hline LSNG & Lâm sản ngoài gỗ \\
\hline NLKH & Nông lâm kết hợp \\
\hline NN\&PTNT & Nông nghiệp và phát triển nông thôn \\
\hline ODA & Hỗ trợ Phát triển Chính thức \\
\hline PCCCR & Phòng cháy chữa cháy rừng \\
\hline QLRBV & Quản lý rừng bền vững \\
\hline RAMSAR & Công ước quốc tế vê bảo tôn và sử dụng đất lâm nghiệp \\
\hline RĐD & Rừng đặc dụng \\
\hline $\mathrm{RPH}$ & Rừng phòng hộ \\
\hline RSX & Rừng sản xuất \\
\hline RTN & Rừng tự nhiên \\
\hline RT & Rừng trông \\
\hline USD & Đô la Mỹ \\
\hline UBND & Ủy ban nhân dân \\
\hline UNCBD & Công ước về đa dạng sinh học \\
\hline UNCCD & Công ước về chống sa mạc hoá \\
\hline UNFCCC & Công ước khung của Liên hợp quốc về biến đổi khí hậu \\
\hline VNTLAS & Hệ thống bảo đảm gỗ hợp pháp Việt Nam \\
\hline VQG & Vườn quốc gia \\
\hline VPA/FLEGT & $\begin{array}{l}\text { Hiệp định Đối tác tự nguyện về thực thi luật lâm nghiệp, quản trị rừng và thương mại } \\
\text { Lâm sản }\end{array}$ \\
\hline
\end{tabular}




\section{Tóm tắt tổng quan}

Chiến lược phát triển lâm nghiệp Việt Nam là một trong những chính sách định hướng quan trọng của ngành. Qua mỗi thời kì, định hướng, mục tiêu và giải pháp của chiến lược có thể khác nhau tùy vào mục tiêu và quan điểm chính trị cũng như định hướng vai trò của ngành lâm nghiệp trong tổng thể phát triển kinh tế xã hội chung của cả nước. Việc kế thừa các bài học kinh nghiệm, phát triển Chiến lược mới dựa trên nền tảng kinh nghiệm thu được từ việc giải quyết khó khăn và tận dụng các cơ hội luôn là ưu tiên hàng đâu của Chính phủ Việt Nam.

Chiến lược phát triển lâm nghiệp đâu tiên tổng thể của Việt Nam được ra đời vào năm 2006 đặt dấu mốc quan trọng cho việc chuyển đổi phát triển ngành lâm nghiệp theo hướng truyền thống vốn chỉ tập trung vào các giá trị trực tiếp của rừng sang cách tiếp cận mới bao gồm tiếp cận ngành, tiếp cận cảnh quan, tiếp cận theo chuỗi và tiếp cận theo dịch vụ môi trường cũng như dịch vụ sinh thái rừng. Tuy nhiên, Chiến lược này sẽ kết thúc vào năm 2020 và Tổng cục Lâm nghiệp (VNFOREST), Bộ NN\&PTNT đang trong quá trình xây dựng Chiến lược phát triển lâm nghiệp giai đoạn 2021-2030 tầm nhìn 2050. Báo cáo này là kết quả hợp tác giữa Tổ chức Nghiên cứu Lâm nghiệp Quốc tế (CIFOR) và Tổng cục lâm nghiệp (VNFOREST) nhằm hỗ trợ thông tin đâu vào cho VNFOREST trong quá trình xây dựng Chiến lược mới. Báo cáo rà soát thành tựu và thách thức trong quá trình thực hiện Chiến lược phát triển lâm nghiệp 2006-2020 đồng thời đưa ra các kiến nghị để các nhà hoạch định chính sách xem xét trong quá trình xây dựng Chiến lược trong giai đoạn mới thông qua nghiên cứu tài liệu thứ cấp và phỏng vấn các bên có liên quan.

Kết quả nghiên cứu chỉ ra rằng, tính tới thời điểm 2020, Việt Nam đã vượt một số chỉ tiêu đề ra trong Chiến lược Phát triển lâm nghiệp Việt Nam giai đoạn 2006-2020 bao gồm: đẩy nhanh tốc độ tăng giá trị sản xuất ngành, nâng cao giá trị xuất khẩu sản phẩm gỗ và lâm sản, nâng cao sản lượng khai thác gỗ trong nước, trông rừng phòng hộ, đặc dụng.
Tuy nhiên, ngành lâm nghiệp còn gặp nhiều thách thức trong việc thực hiện một số chỉ tiêu quan trọng khác như: nâng cao diện tích rừng sản xuất (RSX) có chứng chỉ Quản lí bảo vệ rừng (QLBVR), nâng cao sản lượng gỗ lớn, nâng cao nguôn thu dịch vụ môi trường rừng (DVMTR), đảm bảo diện tích giao và cho thuê rừng và đất lâm nghiệp, giảm số hộ nghèo ở các vùng lâm nghiệp trọng điểm, và nâng cao tỷ lệ lao động lâm nghiệp được đào tạo. Mặc dù có một số chỉ tiêu đề ra trong chiến lược cũ không thể đạt được như dự kiến, nhưng so với một số mục tiêu phát triển ngành lại vượt trội, ví dụ như: tỷ lệ che phủ rừng, trồng lại rừng sau khi thác, giảm các vụ vi phạm vê bảo vệ rừng, trồng cây phân tán. Các mục tiêu đã đạt được hoặc vượt mục tiêu đề ra là nhờ có sự cam kết chính trị mạnh mẽ của chính phủ, chính sách phù hợp với xu thế và thị trường, năng lực quản lí của trung ương và địa phương đã được cải thiện và sự hỗ trợ tích cực của các nhà tài trợ quốc tế, sự tham gia của các tổ chức dân sự và khối tư nhân. Việc chưa đạt được một số các chỉ tiêu đề là do khó khăn trong việc thực hiện chính sách hiệu quả, hiệu ích và công bằng tại cấp cơ sở đi kèm với thiếu hụt về nguôn lực và nguôn vốn và một số mục tiêu và chỉ tiêu tham vọng không thực tế trong bối cảnh kinh tế, chính trị, và thị trường. Để giải quyết các nguyên nhân này cần có cách tiếp cận mới và các giải pháp kinh tế, xã hội và kĩ thuật hiệu quả hơn. Việc xây dựng Chiến lược phát triển lâm nghiệp giai đoạn 2021-2030 tầm nhìn 2050 cần xem xét cả thành tựu lẫn thách thức trong quá trình thực hiện chính sách giai đoạn trước, đón đâu các xu thế toàn cầu và hài hóa hóa trong bối cảnh phát triển chính trị, kinh tế, xã hội của cả nước.

Định hướng phát triển của Chiến lược mới cũng cần phải xem xét trong bối cảnh hội nhập hóa với các yêu cầu quốc tế để tạo điều kiện cho việc huy động nguôn tài chính trong nước và ngoài nước giúp hiện đại hóa ngành, nâng cao vai trò và giá trị của ngành trong việc xóa đói giảm nghèo, phát triển kinh tế bền vững và cung cấp hệ sinh thái rừng bền vững. 



\section{Giới thiệu}

Chiến lược phát triển Lâm nghiệp Việt Nam giai đoạn 2006-2020 được Thủ tướng Chính phủ phê duyệt tại Quyết định số 18/2007/QĐ-TTg ngày $05 / 02 / 2007$. Trong gần 15 năm qua, ngành Lâm nghiệp đã nỗ lực triển khai thực hiện thông qua nhiều chương trình, kế hoạch và đề án khác nhau trong từng giai đoạn; đạt nhiều thành tựu quan trọng, góp phần nâng cao nhận thức và thu hút sự quan tâm, ủng hộ của toàn xã hội đối với tài nguyên rừng, đông thời đóng góp tích cực vào phát triển kinh tế - xã hội, bảo vệ môi trường và ứng phó với biến đổi khí hậu của đất nước (Tổng cục Lâm nghiệp 2020a).

Bên cạnh các thành tựu, ngành Lâm nghiệp cũng còn một số tôn tại như công tác quy hoạch và quản lý quy hoạch còn hạn chế; tình trạng tranh chấp đất đai, vi phạm các qui định vể bảo vệ và phát triển rừng vẫn diễn ra phức tạp, có nơi nghiêm trọng; diện tích rừng tăng nhưng chất lượng còn thấp, rừng tự nhiên (RTN) phục hôi chậm, năng suất rừng trồng $(\mathrm{RT})$ tuy được cải thiện nhưng vẫn còn thấp, chủ yếu gỗ nhỏ, chưa đáp ứng nhu cầu nguyên liệu cho công nghiệp chế biến, xuất khẩu (Tổng cục Lâm nghiệp 2020a).

Năm 2020 là một mốc quan trọng trong quá trình xây dựng các chủ trương, chính sách và chiến lược, kế hoạch phát triển kinh tế - xã hội của đất nước cũng như ngành Lâm nghiệp Việt
Nam. Việc tổng kết, đánh giá kết quả thực hiện Chiến lược phát triển Lâm nghiệp giai đoạn 20062020 và xây dựng Chiến lược phát triển Lâm nghiệp Việt Nam giai đoạn tới để làm căn cứ định hướng cho phát triển ngành Lâm nghiệp là rất cân thiết. Bộ Nông nghiệp và Phát triển Nông thôn đã ban hành Quyết định số 4587/QĐ-BNN-TCLN ngày 09/11/2017 để triển khai thực hiện nhiệm vụ này.

Báo cáo này là sản phẩm hợp tác giữa Tổ chức Nghiên cứu Lâm nghiệp Quốc tế (CIFOR), và Vụ Kế hoạch - Tài chính của Tổng cục Lâm nghiệp, Bộ Nông nghiệp và Phát triển Nông thôn. Mục tiêu của Báo cáo là đánh giá một cách đầy đủ, khách quan về kết quả thực hiện Chiến lược phát triển Lâm nghiệp Việt Nam giai đoạn 2006-2020, phân tích các thành tựu cũng như các tồn tại, hạn chế và nguyên nhân, rút ra các bài học kinh nghiệm làm cơ sở đề xuất, khuyến nghị các vấn đê cần được xem xét, giải quyết trong xây dựng Chiến lược phát triển Lâm nghiệp Việt Nam giai đoạn 2021-2030, tâm nhìn đến năm 2050.

Báo cáo được xây dựng trên cơ sở tổng quan các nguôn tài liệu thứ cấp bao gồm báo cáo của các cơ quan chính phủ trung ương và địa phương, báo cáo của các tổ chức trong và ngoài nước, báo cáo kết quả thực hiện Chiến lược phát triển Lâm nghiệp Việt Nam giai đoạn 2006-2020 của các địa phương, kết hợp với kết quả tham vấn với đại diện của 32 tổ chức có liên quan. 


\section{Phương pháp}

Báo cáo này được thực hiện dựa trên ba phương pháp tiếp cận.

Rà soát tài liệu thứ cấp. Nhóm nghiên cứu rà soát các báo cáo khoa học, các báo cáo của các nhà tài trợ, cơ quan chính phủ, các cơ quan nghiên cứu trong và ngoài nước và doanh nghiệp, các nhà tài trợ liên quan đến hiệu quả thực hiện chính sách lâm nghiệp trong giai đoạn 2006-2020 cũng như để xuất về định hướng phát triển lâm nghiệp Việt Nam trong giai đoạn 2021-2030, tâm nhìn 2050.

Ngoài ra, nhóm tác giả đã tham khảo 49 báo cáo kết quả thực hiện Chiến lược phát triển Lâm nghiệp Việt Nam giai đoạn 2006-2020 của 49 tỉnh ${ }^{1}$, thành phố trực thuộc trung ương có rừng. Báo cáo của các tỉnh được thực hiện theo yêu cầu tại văn bản số 1549/TCLN-KHTC ngày 03/10/2019 của Tổng cục Lâm nghiệp.

Phỏng vấn sâu với các tổ chức và chuyên gia độc lập. Nhóm tác giả đã phỏng vấn với 22 cán bộ các cơ quan nhà nước và 18 chuyên gia từ các tổ chức liên quan. Nội dung phỏng vấn tập trung vào:

- Thành tựu và thách thức trong việc thực hiện Chiến lược Phát triển Lâm nghiệp năm 20062020

- Quan điểm của các bên có liên quan trong việc xây dựng chiến lược và định hướng phát triển Lâm nghiệp trong giai đoạn mới
- Định hướng và Bài học kinh nghiệm trong việc thực hiện của các Chiến lược khác, ví dụ Chiến lược khoa học công nghệ quốc gia, Chiến lược bảo tôn đa dạng sinh học, Chiến lược Nghiên cứu ngành lâm nghiệp, Chiến lược đào tạo nguồn nhân lực, Nghị định 99 và 156 về Chi trả dịch vụ môi trường rừng

- Kết quả thực hiện các Chương trình, kế hoạch lâm nghiệp và định hướng 2021-2030

Đánh giá dựa theo hệ thống đèn giao thông. Để thuận tiện cho việc đánh giá, chúng tôi sử dụng tín hiệu đèn giao thông để đánh giá mực đạt được của các chỉ tiêu và chương trình được đề ra trong Chiến lược phát triển lâm nghiệp 2006-2020.

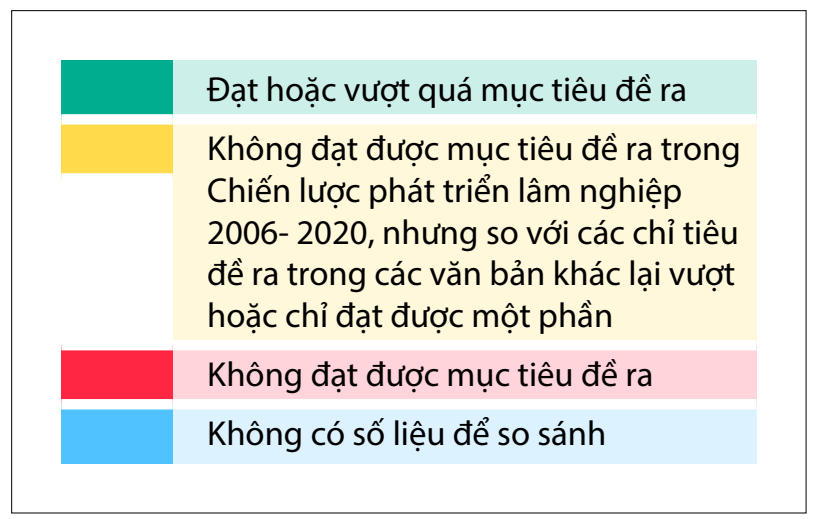

1 Điện Biên, Nam Định, Đăk Lăk, Sơn La,Thái Bình, Đăk Nông,Hòa Bình,Ninh Bình,Đông Nai,Lào Cai, Thanh Hóa, Bà Rịa V.Tàu,Hà Giang,Nghệ An,Bình Dương, Tuyên Quang,Hà Tĩnh,Bình Phước,Phú Thọ, Quảng Bình,Tây Ninh,Cao Bằng,T. Thiên Huế,Long An,Bắc Kạn,TP Đà Nẵng,Tiên Giang, Quảng Ninh, Quảng Nam,Hậu Giang,Lạng Sơn, Quảng Ngãi,Sóc Trăng,Bắc Giang,Bình Định,Bạc Liêu,Bắc Ninh,Phú Yên,An Giang, Hải Phòng, Ninh Thuận,Kiên Giang, Hải Dương,Bình Thuận,Cà Mau,TP Hà Nội, Kon Tum,Hà Nam,Gia Lai. 


\section{Thông tin tổng quan - Mục tiêu, định hướng và cách tiếp cận của chiến lược 2006-2020}

Chiến lược phát triển Lâm nghiệp (PTLN) Việt Nam giai đoạn 2006-2020 được Thủ tướng Chính phủ phê duyệt tại Quyết định số 18/2007/QĐ-TTg với mục tiêu tổng quát là "Thiết lập, quản lý, bảo vệ, phát triên và sử dưng bên vũng 16,24 triệu ha đất quy hoạch cho lâm nghiệp; Nâng tỷ lệ đất có rǜng lên 42-43\% vào năm 2010 và $47 \%$ vào năm 2020. Đảm bảo có sự tham gia rộng rãi của các thành phân kinh tế và tổ chức xã hội vào phát triên Lâm nghiệp nhằm đóng góp ngày càng tăng vào phát triên kinh tế - xã hội, bảo vệ môi trường sinh thái, bảo tôn đa dạng sinh học và cung cấp các dịch vu môi truờng, góp phân xóa đói giảm nghèo, nâng cao múc sống cho người dân nông thôn miền núi và giữ vũng an ninh quốc phòng".

Chiến lược PTLN 2006-2020 đã đưa ra 4 định hướng (Hình 1 ) và 7 giải pháp thực hiện (Hình 2) thông qua 5 chương trình (Hình 3 ) với tổng nhu cầu vốn để thực hiện Chiến lược PTLN giai đoạn 2006-2010 được dự tính là 33.885,34 tỷ đông, bao gồm các nguồn: ngân sách Nhà nước 23,9\%, tín dụng Nhà nước 15,6\%, ODA 13,1\%, Doanh nghiệp nhà nước và Hợp tác xã (HTX) 11,3\%, FDI $24,5 \%$, nguôn khác $0,4 \%$.

Tuy nhiên trong thực tế, ngành Lâm nghiệp không tổ chức thực hiện Chiến lược PTLN 2006-2020 theo các chương trình đã được phê duyệt tại Quyết định 18 của Thủ tướng Chính phủ mà thực hiện các chương trình, dự án được xây dựng và ban hành theo 3 giai đoạn (2006-2010, 2011-2016, và 2017-2020. Đánh giá về tiến độ và kết quả thực hiện được thể hiện trong các phân dưới đây.

\subsection{Giai đoạn 2006-2010}

Giai đoạn 2006-2010 tiếp tục thực hiện Dự án trông mới 5 triệu ha rừng (Chương trình 661 theo Quyết định 661/QĐ-TTg ngày 29/7/1998 của Thủ tướng Chính phủ). Để thực hiện Dự án 5 triệu ha

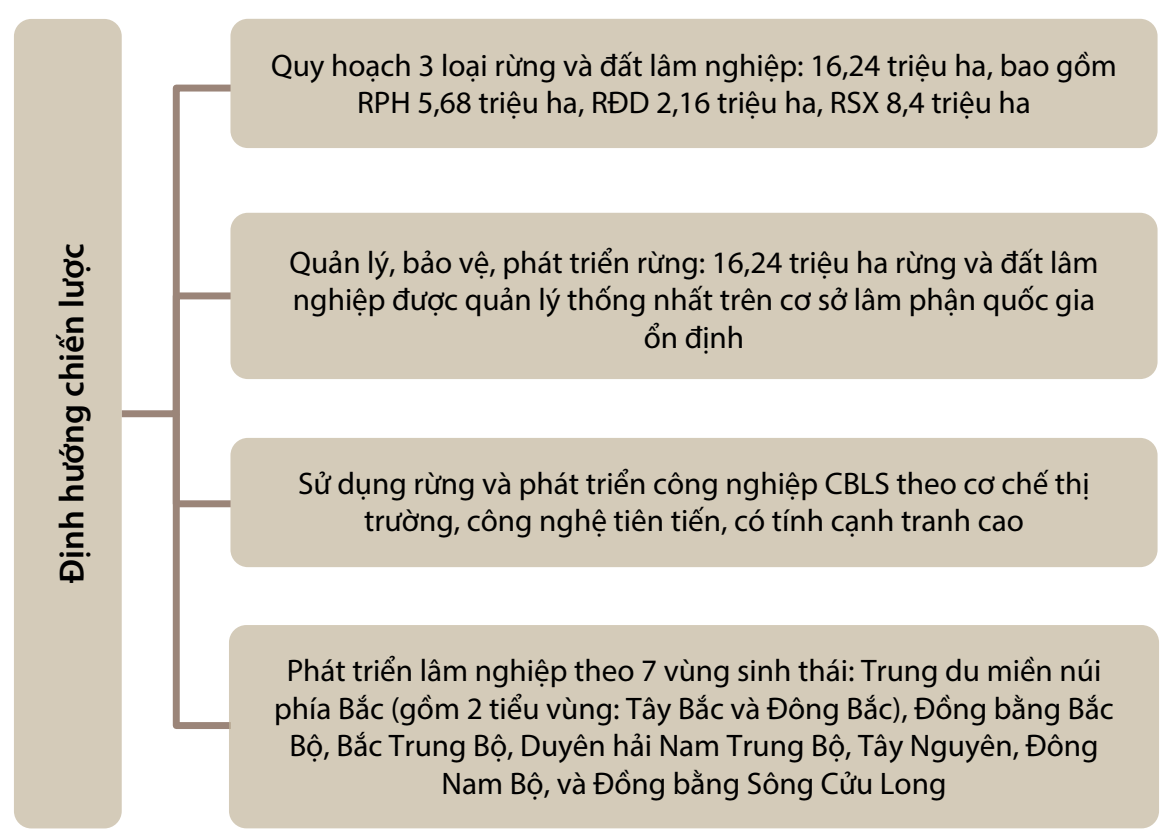

Hình 1. Bốn định hướng chiến lược 
1. Đổi mới chính sách về quản lý rừng, đất lâm nghiệp, tài chính và tín dụng

2. Đổi mới hệ thống sản xuất, kinh doanh

3. Quy hoạch, kế hoạch và giám sát

4. Tổ chức quản lý ngành

5. Khoa học công nghệ

6. Đào tạo nguồn nhân lực

7. Hợp tác quốc tế

Hình 2. Bảy giải pháp thực hiện chiến lược

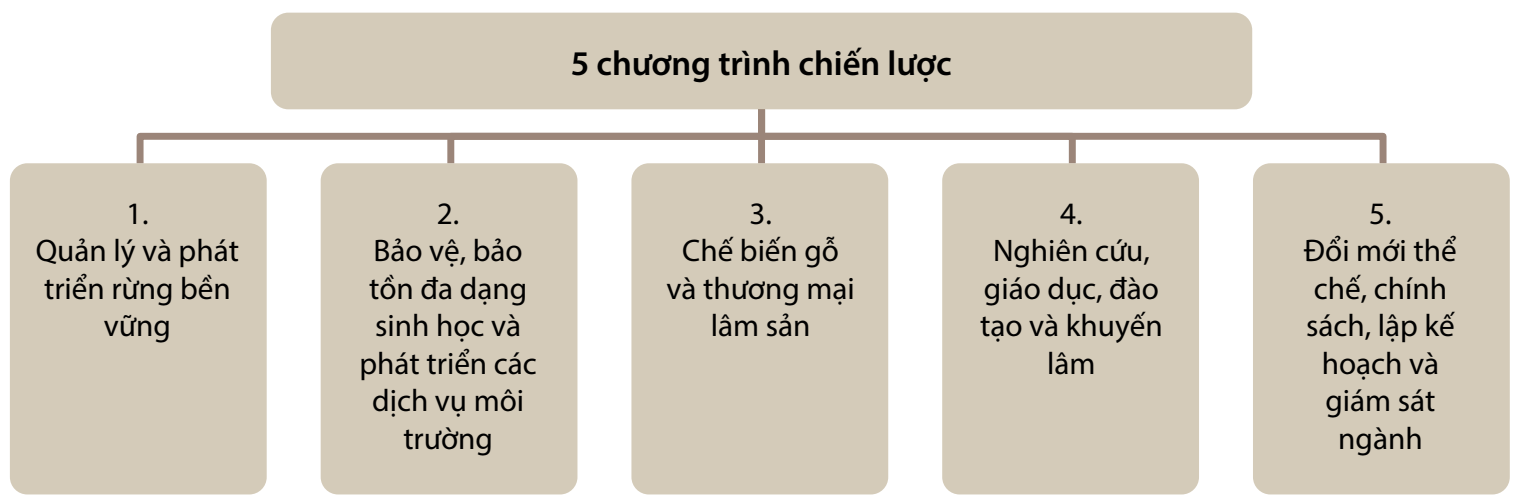

Hình 3. Năm chương trình mục tiêu trong chiến lược

rừng, ở Trung ương đã thành lập Ban chỉ đạo Nhà nước và Ban Điều hành dự án Trung ương theo Quyết định của Thủ tướng Chính phủ; ở các địa phương thành lập Ban Điều hành hoặc Ban chỉ đạo dự án cấp tỉnh do lãnh đạo UBND tỉnh làm trưởng ban, và Ban quản lý dự án cấp tỉnh do lãnh đạo Sở NN-PTNT làm trưởng ban; các dự án cơ sở có Ban quản lý dự án (Chính phủ Việt Nam 2011). Hệ thống tổ chức chỉ đạo điều hành tương tự được tiếp tục duy trì và củng cố ở các giai đoạn tiếp theo, trong đó tên gọi được thay đổi để phù hợp.
Chiến lược PTLN Việt Nam 2006-2020 được xây dựng với sự hỗ trợ tích cực, hiệu quả của nhiều tổ chức quốc tế thông qua Đối tác hỗ trợ ngành lâm nghiệp (FSSP) đã đưa ra các định hướng phát triển ngành Lâm nghiệp một cách toàn diện. Từ năm 2004, để giám sát ngành, FSSP đã hỗ trợ Bộ NN-PTNT xây dựng Hệ thống thông tin giám sát ngành Lâm nghiệp (FORMIS) với một bộ chỉ số gồm 36 chỉ tiêu. Năm 2006, bộ chỉ số được sửa đổi, bổ sung để giám sát và đánh giá việc thực hiện chiến lược PTLN 2006-2020 gồm 72 chỉ tiêu, trong đó có 15 chỉ tiêu quan trọng 
nhưng lúc đó chưa có số liệu được gọi là "chỉ tiêu tương lai". Bộ chỉ số được phân thành 4 nhóm: i) Mục tiêu tổng quát có 4 chỉ tiêu; ii) các mục tiêu cụ thể về kinh tế, xã hội và môi trường có 13 chỉ tiêu; iii) Các chỉ tiêu thực hiện theo các chương trình có 47 chỉ tiêu; và iv) các chỉ tiêu đầu vào gồm 8 chỉ tiêu (Bộ NN-PTNT, FSSP 2010).

Báo cáo về ngành Lâm nghiệp năm 2006 với hệ thống chỉ tiêu nêu trên được xem là Báo cáo cơ sở để theo dõi, giám sát việc thực hiện Chiến lược PTLN 2006-2020. Năm 2010, Bộ NNPTNT với sự hỗ trợ của FSSP đã xây dựng "Báo cáo tiến độ ngành Lâm nghiệp 2006-2010" nhằm phân tích sự thay đổi của ngành lâm nghiệp trong 5 năm đâu thực hiện chiến lược, nguyên nhân đạt và không đạt các chỉ tiêu quan trọng của ngành, xu hướng phát triển lâm nghiệp Việt Nam và thế giới và đưa ra các khuyến nghị.

Theo Bộ NN-PTNT, FSSP (2010), giai đoạn 2006-2010, ngành lâm nghiệp đã đạt được nhiều thành tựu quan trọng:

- Các hoạt động lâm nghiệp đã chuyển từ dựa vào quốc doanh sang lâm nghiệp xã hội với nhiêu thành phân kinh tế tham gia, trong đó vai trò nòng cốt trong trông rừng là các hộ gia đình và CBLS là doanh nghiệp tư nhân.

- Các dự án lâm nghiệp được thực hiện hiệu quả, nhất là $\mathrm{DA} 661$ và các $\mathrm{DA} \mathrm{ODA}$ đã làm thay đổi nhận thức của các cơ quan chính phủ và xã hội về vai trò, tác dụng của rừng.

- Tăng trưởng giá trị sản xuất lâm nghiệp đạt bình quân $2,8 \% /$ năm; GDP lâm nghiệp chiếm khoảng 1\% GDP quốc gia (nếu tính đủ GDP có thể đạt 3-5\%);

- Xuất khẩu đô gỗ đạt 3,2 tỷ USD năm 2010 đạt mục tiêu chiến lược đề ra.
- Độ che phủ rừng tăng từ 37\% năm 2015 lên 39,5\% năm 2010 nhưng không đạt mục tiêu chiến lược.

- Sản lượng khai thác gỗ tăng từ 3,2 triệu $\mathrm{m}^{3}$ năm 2006 lên 4,95 triệu $\mathrm{m}^{3}$ năm 2010, trong đó gỗ rừng trồng chiếm $92 \%$.

- Tỷ lệ nghèo đã giảm trong giai đoạn 2006-2009 ở các tỉnh nhiều rừng, trong đó từ năm 2004 đến 2008, vùng Trung du miên núi phía Bắc giảm từ 38,35\% xuống 31,6\%, vùng Bắc Bộ trung bộ và Duyên hải Miền trung từ 25,9\% xuống 18,4\%, vùng Tây Nguyên từ 33,1\% xuống 24,1\%. Nhiều tiến bộ kỹ thuật, nhất là giống, được đưa vào sản xuất, góp phân tăng năng suất, chất lượng rừng trồng, có nơi đạt $15-20 \mathrm{~m}^{3} / \mathrm{ha} / \mathrm{năm}$.

- Nhiêu chính sách đột phá được ban hành: Quyết định 147/2007/QĐ-TTg vê phát triển RSX đã đưa diện tích rừng trồng SX đạt 838.830 ha bằng $112 \%$ kế hoạch; Quyết định $380 / 2007 / Q Đ-T T g$ về thí điểm và sau đó là Nghị dịnh 99/2010/NQQ-CP về chính sách chi trả DVMTR đã đưa Việt Nam thành nước đầu tiên ở Đông Nam Á thực hiện chi trả DVMTR; Nghị định 117/2010/NĐ-CP về tổ cức quản lý rừng đặc dụng.

Mặt khác, giai đoạn 2006-2010 ngành lâm nghiệp tập trung thực hiện Dự án 5 triệu ha rừng nên cuối giai đoạn này việc tổng kết, đánh giá chủ yếu dựa trên kết quả thực hiện Quyết định 661/QĐ-TTg ngày 29/7/1998 của Thủ tướng Chính phủ về mục tiêu, nhiệm vụ, chính sách và tổ chức thực hiện Dự án trồng mới 5 triệu ha rừng và Nghị quyết số 73/2006/QH ngày 29/11/2006 của Quốc hội Khoa XI về điều chỉnh chỉ tiêu, nhiệm vụ của Dự án Trông mới 5 triệu ha rừng giai đoạn 2006-2020 (Chính phủ Việt Nam 2011, xin xem thêm Hộp 1).

\section{Hộp 1. Kết quả Dự án trồng mới 5 triệu ha rừng giai đoạn 2006-2010}

- Trồng rừng 1.140.630 ha, đạt $114 \%$ kế hoạch

- Khoanh nuôi xúc tiến tái sinh 922.768 ha , đạt 115\% kế hoạch

- Chăm sóc rừng 1.351.019 ha (đạt 95\% KH)

- Khoán bảo vệ rừng 2.507.355 ha (đạt 167\% kế hoạch)

- Độ che phủ rừng năm 2010 là 39,5\% tăng 2,4\% so với 2005.

- Tổng trữ lượng gỗ cả nước năm 2010 là 935,3 triệu m³ , tăng 15\% so với năm 2005

- Khai thác gỗ rừng trồng 5 triệu $\mathrm{m}^{3}$ năm 2010

- Góp phần tạo việc làm, xóa đói giảm nghèo. 
Theo Phạm và cộng sự (2012), trong giai đoạn 2006-2009, diện tích rừng của Việt Nam tăng lên là chủ yếu do rừng trồng, nhà nước đã tiến hành công cuộc cải cách đất lâm nghiệp quốc gia, áp dụng công nghệ mới, các cơ hội thị trường đối với các loại sản phẩm lâm nghiệp và sự tự do hóa và gia tăng sản lượng nông nghiệp. Ngoài ra, một phần cũng là là do phân lại loại rừng và gộp cả diện tích rừng đã bỏ qua vào phân loại rừng trước đây và diện tích rừng tự nhiên tái sinh chủ yếu là diện tích rừng tre nứa.

Tuy nhiên, Bộ NN-PTNT, FSSP (2010) cũng chỉ ra lâm nghiệp còn một số tồn tại:

- Tăng trưởng ngành lâm nghiệp còn thấp và chưa bền vững, lợi nhuận ít, sức cạnh tranh yếu, tiềm năng của rừng chưa được khai thác hợp lý nhất là gỗ lớn, LSNG và DVMTR.

- Rừng trồng và RTN năng suất, chất lượng thấp chưa đáp ứng nhu câuu nguyên liệu gỗ lớn cho chế biến và xuất khẩu.

- Công nghiệp chế biến gỗ và LSNG tuy phát triển nhanh nhưng tự phát, chưa vững chắc, thiếu quy hoạch và tầm nhìn chiến lược, cạnh tranh thấp, sản xuất gia công là chính, thiếu công nghiệp phù trợ, chưa xây dựng được thương hiệu thiếu vốn đầu tư cho công nghiệp hiện đại, nguôn gỗ chủ yếu nhập khẩu.

- Tác động của ngành đối với xóa đói giảm nghèo còn rất hạn chế,

- Tác động của rừng với môi trường còn hạn chế; vai trò của rừng tự nhiên đối với phòng hộ và bảo tồn đa dạng sinh học còn hạn chế.

- Khó khăn bao trùm của ngành là thiếu vốn cho cả 3 loại rừng; vốn ngân sách cho lâm nghiệp thấp và chưa công bằng so với các ngành khác.

Ngoài ra, trong giai đoạn này diện tích rừng tự nhiên vẫn tiếp tục giảm và rừng ngập mặn cũng bị suy thoái nghiêm trọng (Phạm và cộng sự 2012). Mặc dù trông rừng đã đem lại kết quả là tăng diện tích có rừng, song số liệu cho thấy phân lớn diện tích là rừng trông thuần loài, còn rừng tự nhiên còn lại thì trong tình trạng là rừng nghèo hoặc đang trong quá trình tái sinh. Hơn thế nữa, xu thế chủ đạo vẫn là phương thức phát triển và quản lý rừng manh mún và do vậy có nhiêu diện tích rừng bị suy thoái và trong giai đoạn này. Rừng tự nhiên nghèo với trữ lượng gỗ dưới $80 \mathrm{~m}^{3} / \mathrm{ha}$ chiếm tới trên $80 \%$ tổng diện tích rừng vào thời điểm 2006-2020 (Phạm và cộng sự 2012).

Báo cáo của Chính Phủ Việt Nam (2011) và Tổng cục Lâm Nghiệp (2010) cũng chỉ ra thành tựu và kết quả chính trong giai đoạn này là nhờ quyết tâm cao của Đảng, Nhà nước, được Quốc Hội thông qua; vận dụng tích cực cơ chế thị trường để thực hiện, quan tâm lợi ích KT-XH người dân sống gân rừng, coi trọng công tác quy hoạch và thực hiện quy hoạch, đẩy mạnh giao đất giao rừng, quyền sử dụng đất lâu dài cho tổ chức, hộ, cá nhân; hoàn thiện chính sách khuyến khích nhiều thành phần kinh tế đâu tư vào trông rừng; tăng cường quản lý nhà nước và phân cấp cho địa phương thực hiện dự án và ứng dụng khoa học công nghệ (KHCN) vê giống, cơ cấu cây trông kỹ thuật thâm canh để nâng cao hiệu quả dự án.

Bộ NN-PTNT và FSSP (2010) cũng đưa ra nhiêu khuyến nghị và định hướng chung cho giai đoạn tiếp theo nhằm giải quyết các khó khăn tồn tại, bao gồm: thay thế dần gỗ nhập khẩu; nâng cao chất lượng RTN và $R T$, hoàn thiện chính sách đâu tư cho rừng phòng hộ $(\mathrm{RPH})$ và rừng đặc dụng (RĐD), hỗ trợ trông RSX là những ưu tiên cao nhất; trông rừng gỗ lớn; quản lý bền vững 3 loại rừng tiến tới cấp chứng chỉ, ưu tiên RTSX; Quy hoạch/kế hoạch sử dụng đất lâm nghiệp, xây dựng lâm phận quốc gia ổn định; đẩy mạnh thực thi chi trả DVMTR; xây dựng các tổng công ty lâm nghiệp làm nòng cốt trông rừng gỗ lớn; giao RTN cho cộng đồng quản lý và sử dụng, giao đất trồng RSX cho hộ miền núi thiếu đất canh tác nông nghiệp; đổi mới công nghệ CBLS để đạt giá trị gia tăng cao , có chính sách hỗ trợ cho đổi mới công nghệ, bao gồm cả công nghiệp phụ trợ. Ngoài ra Bộ NN-PTNT và FSSP (2010) cũng nhấn mạnh sự cân thiết để cải tiến bộ chỉ tiêu giám sát ngành và thu thập số liệu, xây dựng báo cáo tiến độ cho Chiến lược cũng như nâng cao sự tham gia của các bên có liên quan trong quá trình hoạch định, thực hiện và giám sát chính sách

\subsection{Giai đoạn 2011-2015}

Giai đoạn này thực hiện Kế hoạch BV\&PTR giai đoạn 2011-2020 (theo Quyết định số 57/QĐTTg ngày 09/01/2012 của Thủ tướng Chính phủ về phê duyệt Kế hoạch bảo vệ và phát triển rừng giai đoạn 2011-2020). Ở trung ương là Ban Chỉ đạo nhà nước về Kế hoạch BV\&PTR và thành lập Văn phòng Ban Chỉ đạo nhà nước về Kế hoạch BV\&PTR giai đoạn 2011-2020; tại địa phương là Ban Chỉ đạo cấp tỉnh về Kế hoạch BV\&PTR.

Theo dự kiến, "Báo cáo tiến độ ngành Lâm nghiệp 2006-2010” là báo cáo tiến độ thứ nhất để đánh 
giá kết quả thực hiện chiến lược PTLN 20062020, tiếp theo sẽ là báo cáo thứ 2 vào năm 2005 và báo cáo thứ 3 năm 2020 (Bộ NN-PTNT, FSSP 2010).Tuy nhiên, từ năm 2010 trở về sau, việc giám sát các hoạt động của ngành lâm nghiệp với hệ thống chỉ tiêu đã thiết lập không được tiếp tục thực hiện một cách đầy đủ và có hệ thống. Hiện nay các thông tin và số liệu có thể dùng để đánh giá thực hiện các mục tiêu của Chiến lược cũ tản mạn và thiếu hệ thống, do vậy rất khó để đánh giá hiệu quả thực hiện của Chiến lược 2006-2020.

Tuy nhiên, năm 2011, Tổng cục Lâm nghiệp đã tổ chức biên soạn và xuất bản cuốn sách "Lâm nghiệp Việt Nam trong thập kỷ đâu của Thế kỷ XXI" đã ghi nhận một số thành tựu trong giai đoạn này bao gồm tài nguyên rừng được phục hồi và phát triển; hệ thống pháp luật, chính sách lâm nghiệp được được sửa đổi, bổ sung và ngày càng hoàn thiện, và hợp tác và hội nhập quốc tế vể Lâm nghiệp mở rộng. Mặt khác, cuốn sách này cũng chỉ ra 5 khó khăn, thách thức đối với ngành lâm nghiệp trong giai đoạn này, bao gồm: i) các thách thức trong quá trình phát triển như thiếu vốn, tranh chấp đất đai, quản lý nhà nước với doanh nghiệp, nhất là lâm trường quốc doanh, thể chế kinh tế thị trường, chất lượng nguồn nhân lực, kết cấu hạ tầng yếu kém: ii) tài nguyên rừng còn nghèo, năng lực sản xuất thấp, kinh tế nông thôn chưa phát triển; iii) nhận thức xã hội chưa đáp ứng yêu cầu phát triển rừng và nghề rừng bền vững; iv) cơ chế, chính sách chưa thúc đầy nâng cao sinh kế cho người làm nghề rừng; $v$ ) chưa nhận diện và phân tích đây đủ các nguyên nhân của những khó khăn, thách thức trong phát triển lâm nghiệp.

Bộ NN-PTNT (2011) cũng cho rằng để ngành lâm nghiệp phát triển tốt trong giai đoạn 2016-2020, cần (i) có nhận thức đúng về quản lý lâm nghiệp bền vững, ii) Tiếp thu và vận dụng phù hợp các xu thế quản lý rừng của thế giới, iii) phát triển kinh tế tư nhân, kinh tế hợp tác và đa dạng hóa các thành phân kinh tế trong lâm nghiệp, iv) đẩy mạnh nghiên cứu KHCN, chuyển giao nhanh công nhệ mới vào sản xuất, v) xác định rõ vai trò và sự can thiệp của nhà nước trong quản lý rừng. Dự báo trong giai đoạn tiếp theo cũng chỉ ra thuận lợi và cơ hội: i) nội lực đã tăng lên, ii) cơ cấu nghề rừng đã có tiến bộ, rừng trông sản xuất tăng, công nghiệp chế biến phát triển, DVMTR có triển vọng, iii) nghề rừng đã tác động đến phát triển kinh tế hộ, góp phân xóa đói giảm nghèo của người dân miền núi, iv) Xã hội hóa nghê rừng được khẳng định.

Tuy nhiên, ngành lâm nghiệp cũng phải giải quyết và đối mặt với 5 khó khăn và thách thức mới của giai đoạn 2016-2020: i) còn nhiêuu rủi ro tiềm ẩn cho PTLNBV, ii) chất lượng phát triển rừng và nghề rừng còn thấp, iii) điều kiện tự nhiên, kinh tế, xã hội có khó khăn mới như đất trông rừng SX ngày càng xấu, khó tiếp cận, bảo vệ rừng tự nhiên hiệu quả thấp, nguồn nhân lực khó khăn,.. iv) phát sinh thách thức lớn trong quản lý rừng tự nhiên đáp ứng yêu cầu bảo tôn và kinh tế, v) Viện trợ không hoàn lại của quốc tế sẽ giảm (Bộ NNPTNT 2011).

Giai đoạn 2011-2015, việc tổng kết, đánh giá kết quả 5 năm đầu của Kế hoạch BV\&PTR giai đoạn 2011-2020 được thực hiện theo Quyết định số 57/ QĐ-TTg ngày 09/01/2012 của Thủ tướng Chính phủ (Chính phủ Việt Nam 2017). Sau đó, Thủ tướng Chính phủ đã phê duyệt Chương trình mục tiêu phát triển Lâm nghiệp bền vững giai đoạn 2016-2020 tại Quyết định số 886/QĐ-TTg ngày 16/6/2017 thay thế cho Quyết định 57 để thực hiện theo cơ chế chương trình mục tiêu quốc gia theo Nghị quyết số 18/2011/NQ-QH13 của Quốc hội khóa XIII (Nguyễn 2019).

\subsection{Giai đoạn 2016-2020}

Giai đoạn này thực hiện Chương trình mục tiêu PTLN bền vũ̃ng giai đoạn 2016-2020 (theo Quyết định số 886/QĐ-TTg ngày 16/6/2017 phê duyệt Chương trình mục tiêu phát triển Lâm nghiệp bền vững giai đoạn 2016-2020) (Chính phủ Việt Nam 2019).

Theo kết quả phỏng vấn với các bên có liên quan giai đoạn 2016-2020 ghi nhận nhiều sự đổi mới cho ngành. Kết quả phỏng vấn với đại diện của VNFOREST chỉ ra rằng Chương trình mục tiêu phát triển lâm nghiệp bền vững giai đoạn 20162020 (gọi tắt là Chương trình 886 ) đã đạt được kết quả quan trọng. Năm 2018, các chỉ tiêu về diện tích rừng trông, độ che phủ rừng, sản lượng gỗ khai thác, giá trị xuất khẩu đồ gỗ và lâm sản đều đạt và vượt so với kế hoạch. Tuy nhiên, báo cáo và đánh giá toàn diện về giai đoạn này với các số liệu minh chứng đang được tổng hợp tiến hành dự kiến hoàn thiện vào cuối năm 2020 do vậy chưa có được đánh giá thời điểm viết báo cáo. 


\section{Kết quả thực hiện các mục tiêu trong chiến lược phát triển lâm nghiệp việt nam 2006-2020}

Chiến lược phát triển lâm nghiệp Việt Nam đề ra các mục tiêu rõ ràng về kinh tế, xã hội và môi trường. Trong các phân dưới đây, chúng tôi lần lượt trình bày các thành tựu cũng như khó khăn trong việc thực hiện các mục tiêu này trong giai đoạn 2006-2020.

\subsection{Kinh tế}

Bảng 1 cho thấy Chiến lược lâm nghiệp 20062020 đề ra 15 chỉ tiêu về kinh tế, trong đó tới năm 2020 có 5 chỉ tiêu đạt và vượt mục tiêu đề ra; 3 chỉ tiêu đạt mục tiêu điều chỉnh; còn 7 chỉ tiêu chưa đạt mục tiêu đề ra.

7 trong 15 chỉ tiêu tuy chưa đạt được như Chiến lược đề ra nhưng đã đánh dấu sự phát triển vượt trội; cụ thể như chương trình chi trả dịch vụ môi trường rừng, tuy chưa đạt được mục tiêu đề ra là 2 tỉ USD/năm nhưng được coi là 1 trong 10 thành tựu nổi bật nhất của ngành lâm nghiệp. Diện tích trông rừng mới tuy chưa đạt nhưng rừng trông đã phát triển mạnh và đáp ứng ngày càng tốt hơn nhu cầu nguyên liệu cho công nghiệp chế biến. Ngoài ra, với tiến độ hiện nay, tuy chưa đạt được mục tiêu đề ra nhưng khả năng đạt được trong thời gian tới là rất khả thi. Tuy nhiên, có chỉ tiêu đề ra quá cao như trông cây phân tán 200 triệu cây/năm là không khả thi; hoặc $30 \%$ rừng sản xuất được cấp chứng chỉ QLRBV là khó đạt vì thủ tục còn phức tạp và năng lực của các chủ rừng còn hạn chế; hoặc tỷ lệ đóng góp của GDP lâm nghiệp vào GDP quốc gia $2-3 \%$ là không thể đạt với cách tính hiện nay.

Theo tổng kết của Tổng cục Lâm nghiệp, có 7 thành tố quyết định những thành tựu kinh tế của ngành lâm nghiệp trong giai đoạn 2006-2020, bao gồm: i) Đổi mới pháp luật và cơ chế, chính sách lâm nghiệp; ii) thực hiện thành công các chương trình phát triển lâm nghiệp như dự án 5 triệu ha, Đê án tái cơ cấu ngành lâm nghiệp và Kế hoạch BV\&PTR giai đoạn 2011-2020, Chương trình Mục tiêu Bảo vệ và PTLNBV giai đoạn 2016-2020; iii) Chính sách chi trả DVMTR; iv) Huy động và sử dụng vốn cho lâm nghiệp thành công; v) Nghiên cứu khoa học và phát triển công nghệ lâm nghiệp; vi) Đào tạo và phát triển nguồn nhân lực lâm nghiệp; vii) tích cực hợp tác và hội nhập quốc tế (Tổng cục lâm nghiệp 2020a).

Các học giả trong nhiều báo cáo khác nhau đã lí giải vì sao một số chỉ tiêu đã không đạt được như mục tiêu kì vọng (Bảng 2).

Chiến lược PTLN 2006-2020 không đặt ra các mục tiêu định lượng cho các vùng sinh thái lâm nghiệp nên việc đánh giá kết quả đạt được bị hạn chế. Tuy nhiên, Bảng 3 cung cấp một bức tranh chung về tình hình thực hiện theo vùng sinh thái vê phát triển ngành chế biến lâm sản.

\subsection{Môi trường}

Chiến lược lâm nghiệp đề ra 4 chỉ tiêu về môi trường. Bảng 4 cho thấy cả 4 chỉ tiêu môi trường đã đạt được theo mục tiêu điều chỉnh vào năm 2020; tuy nhiên, nếu so với mục tiêu của chiến lược thì chỉ có 1 chỉ tiêu đạt được là diện tích trồng rừng phòng hộ và đặc dụng. Đáng chú ý là tỉ lệ che phủ rừng chỉ đạt được sau điều chỉnh lần 2; việc không đạt tỉ lệ che phủ rừng 47\% có nguyên nhân cơ bản là mục tiêu này quá tham vọng, không khả thi vì tương đương với 15,55 triệu ha phải là rừng, bằng $95,7 \%$ tổng diện tích tự nhiên quy hoạch cho lâm nghiệp là 16,24 triệu ha bao gôm cả các sông, hô, núi đá, cơ sở hạ tâng, giao thông,... ${ }^{2}$

2 Theo NQ số 134/2016/QH13 ngày 09/4/2016 về điều chỉnh $\mathrm{QH}$ sử dụng đất đến năm 2020 và $\mathrm{KH}$ sử dụng đất 2016-2020 tổng diện tích tự nhiên quy hoạch cho lâm nghiệp là 16,24 triệu ha 
Bảng 1. Mục tiêu kinh tế và kết quả thực hiện

\begin{tabular}{|c|c|c|c|c|c|c|c|}
\hline \multirow[b]{2}{*}{ TT } & \multirow[b]{2}{*}{ Mục tiêu, nhiệm vụ } & \multirow{2}{*}{$\begin{array}{l}\text { Năm } \\
2006\end{array}$} & \multirow{2}{*}{$\begin{array}{l}\text { Mục tiêu } \\
\text { chiến lược } \\
\text { (QĐ 18) }\end{array}$} & \multirow{2}{*}{$\begin{array}{l}\text { Mục tiêu } \\
\text { điê̂u } \\
\text { chỉnh }\end{array}$} & \multirow{2}{*}{$\begin{array}{c}\text { Kết quả } \\
\text { thực hiện } \\
2020\end{array}$} & \multicolumn{2}{|c|}{ Đánh giá } \\
\hline & & & & & & $\begin{array}{l}\text { So với mục } \\
\text { tiêu CL }\end{array}$ & $\begin{array}{l}\text { So với mục tiêu } \\
\text { điều chỉnh }\end{array}$ \\
\hline 1 & $\begin{array}{l}\text { Tốc độ tăng giá trị sản xuất } \\
\text { lâm nghiệp (\%/năm) }\end{array}$ & 1,9 & $3,5-4,0$ & $5,5-6,0^{1}$ & 4,87 & Đạt & Đạt \\
\hline 2 & $\begin{array}{l}\text { Tỷ trọng GDP lâm nghiệp/ } \\
\text { GDP quốc gia (\%) }\end{array}$ & $<1$ & $2-3$ & & 0,65 & Không đạt & Không đạt \\
\hline 3 & $\begin{array}{l}\text { Thiết lập, quản lý, bảo vệ, } \\
\text { phát triển và sử dụng bền } \\
\text { vững } 3 \text { loại rừng }\end{array}$ & 12,52 & $16,24^{2}$ & $14,4^{3}$ & 14,60 & Không đạt & Đạt \\
\hline 4 & $\begin{array}{l}\text { Diện tích rừng sản xuất có } \\
\text { CCR }\end{array}$ & & $30 \%$ & $\begin{array}{l}0,1 \text { triệu } \\
\text { ha/năm }\end{array}$ & 269.163 ha & Không đạt ${ }^{5}$ & Không đạt \\
\hline 5 & Trồng rừng mới (triệu ha) & & 1,5 & $0,125^{6}$ & 1,233 & Không đạt ${ }^{7}$ & Đạt 98,6\% \\
\hline 6 & $\begin{array}{l}\text { Trồng lại rừng sau khai } \\
\text { thác (triệu ha/năm) }\end{array}$ & 0,184 & 0,3 & $0,135^{8}$ & 0,235 & Không đạt ${ }^{9}$ & Đạt \\
\hline 7 & $\begin{array}{l}\text { Khoanh nuôi tái sinh rừng } \\
\text { (triệu ha/năm) }\end{array}$ & & 0,8 & $0,36^{10}$ & 0,34 & $\begin{array}{l}\text { Không } \\
\text { đạt }{ }^{11}\end{array}$ & Không đạt \\
\hline 8 & $\begin{array}{l}\text { Trông cây phân tán (triệu } \\
\text { cây/năm) }\end{array}$ & 202,5 & 200 & $50^{1213}$ & 63 & $\begin{array}{l}\text { Không } \\
\text { đạt }^{14}\end{array}$ & Đạt \\
\hline 9 & $\begin{array}{l}\text { Sản lượng gỗ trong nước } \\
\text { (triệu m³/năm) }\end{array}$ & 3,01 & $20-24$ & & 20,5 & Đạt ${ }^{15}$ & Đạt \\
\hline $9 a$ & $\begin{array}{l}\text { Sản lượng khai thác gỗ lớn } \\
\text { (triệu m³) }\end{array}$ & & 10 & & $3-4$ & Không đạt & Không đạt \\
\hline 10 & $\begin{array}{l}\text { Gỗ củi cho khu vực nông } \\
\text { thôn (triệu m³/năm). }\end{array}$ & 26,07 & $25-26$ & & 19,5 ste & Không đạt & Không đạt \\
\hline 11 & Xuất khẩu lâm sản (tỷ USD) & 2,17 & 7,8 & $8,0-8,5^{16}$ & 12,0 & Đạt ${ }^{17}$ & Đạt \\
\hline $11 \mathrm{a}$ & Sản phẩm gỗ (tỷ USD) & 1,94 & 7,0 & & 11,3 & Đạt ${ }^{18}$ & Đạt \\
\hline $11 b$ & Lâm sản ngoài gỗ (tỷ USD) & 0,23 & 0,8 & & 0,9 & Đạt & Đạt \\
\hline 12 & Thu từ DVMTR (tỷ USD) & & 2,0 & & 0,728 & Không đạt & Không đạt \\
\hline
\end{tabular}

1 Quyết định số 886/QĐ-TTg ngày 16/6/2017 phê duyệt Chương trình mục tiêu phát triển Lâm nghiệp bền vững giai đoạn 2016-2020

2 Nghị quyết 134/2016/QH13

3 Quyết định số 886/QĐ-TTg ngày 16/6/2017 phê duyệt Chương trình mục tiêu phát triển Lâm nghiệp bền vững giai đoạn 2016-2020

4 Quyết định số 886/QĐ-TTg ngày 16/6/2017 phê duyệt Chương trình mục tiêu phát triển Lâm nghiệp bền vững giai đoạn 2016-2020

5 Báo cáo của TCLN; VP 886

6 Quyết định số 57/QĐ-TTg ngày 09/01/2012 của Thủ tướng Chính phủ về phê duyệt Kế hoạch bảo vệ và phát triển rừng giai đoạn 2011-2020, theo đó trồng mới 0,125 triệu ha/năm, trong đó RSX 0,1tr ha, RPH, ĐD 0,025tr. ha/năm

7 Theo các QĐ Công bố hiện trạng rừng của Bộ NN-PTNT

8 Quyết định số 57/QĐ-TTg ngày 09/01/2012 của Thủ tướng Chính phủ về phê duyệt Kế hoạch bảo vệ và phát triển rừng giai đoạn 2011-2020, theo đó trồng mới 0,125 triệu ha/năm, trong đó RSX 0,1 tr ha, RPH, ĐD 0,025tr. ha/năm

9 Theo các QĐ Công bố hiện trạng rừng của Bộ NN-PTNT

10 Quyết định số 886/QĐ-TTg ngày 16/6/2017 phê duyệt Chương trình mục tiêu phát triển Lâm nghiệp bền vững giai đoạn 2016-2020

11 Số liệu tổng hợp của TCLN: diện tích khoanh nuôi tái sinh bình quân giai đoạn 2006-2010 là 0,64 tr. lượt ha/năm; giai đoạn 2011-2015 là 0,36 tr. ha/năm và giai đoạn 2016-2019 là 0,315 tr. ha/năm.

12 Quyết định số 886/QĐ-TTg ngày 16/6/2017 phê duyệt Chương trình mục tiêu phát triển Lâm nghiệp bền vững giai đoạn 2016-2020. Nghị quyết 134/2016/QH13

13 Quyết định số 57/QĐ-TTg ngày 09/01/2012 của Thủ tướng Chính phủ về phê duyệt Kế hoạch bảo vệ và phát triển rừng giai đoạn 2011-20201 m

14 Báo cáo của TCLN; VP 886

15 Theo các QĐ Công bố hiện trạng rừng của Bộ NN-PTNT

16 Quyết định số 886/QĐ-TTg ngày 16/6/2017 phê duyệt Chương trình mục tiêu phát triển Lâm nghiệp bền vững giai đoạn 2016-2020

17 Số liệu thống kê và báo cáo của TCLN

18 Số liệu thống kê và báo cáo của TCLN

Nguồn: Tác giả tổng hợp từ tài liệu của TCLN, 2020 
Bảng 2. Nguyên nhân không đạt được các mục tiêu đề ra trong chiến lược

\begin{tabular}{|c|c|}
\hline $\begin{array}{l}\text { Mục tiêu, nhiệm vụ không đạt } \\
\text { mục tiêu để ra }\end{array}$ & Lí do không đạt được mục tiêu \\
\hline $\begin{array}{l}\text { Tỷ trọng GDP lâm nghiệp/GDP } \\
\text { quốc gia (\%) }\end{array}$ & 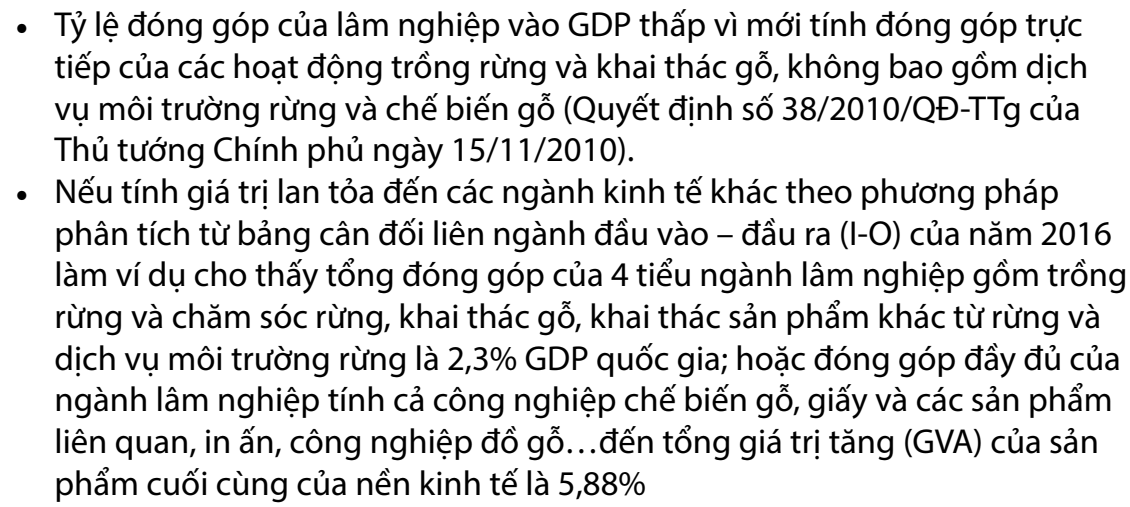 \\
\hline
\end{tabular}

Thiết lập, quản lý, bảo vệ, phát triển và sử dụng bền vững 3 loại rừng

- Từ năm 2010 đến 2017, diện tích các vùng rừng được bảo vệ để bảo tồn đa dạng sinh học hoặc rừng đặc dụng đã tăng, trong khi diện tích rừng phòng hộ lại giảm trong năm 2016 (Phạm và cộng sự 2020b)

- Mặc dù tổng diện tích rừng do cộng đồng quản lý vào năm 2017 đã tăng gấp đôi so với 2005, diện tích rừng do cộng đồng và hộ gia đình quản lý vẫn còn thấp hơn nhiều so với kế hoạch ban đầu của chính phủ với mong muốn bàn giao các diện tích đang được quản lý bởi các công ty nhà nước kém hiệu quả cho hộ gia đình và cộng đồng. Hiện vẫn còn một diện tích lớn đất rừng thu hồi từ các công ty lâm nghiệp nhà nước chưa được chuyển giao cho cộng đồng (Phạm và cộng sự 2020b).

Diện tích rừng sản xuất có $\mathrm{CCR}$

- Năm 2009, Việt Nam chỉ có một chứng chỉ rừng bền vứng do FSC cung cấp cho 9904 ha rừng trồng nhưng có khoảng 170 FSC giấy chứng nhận chuỗi hành trình sản phẩm. Mới có được một diện tích nhỏ như vậy chủ yếu là vì sự khan hiếm và chi phí cao của sản phẩm gỗ được cấp chứng chỉ (Phạm và cộng sự 2012). Đến năm 2016, chỉ 220.000 ha, tương đương với 5,3\% tổng diện tích rừng trồng được cấp chứng chỉ (Phạm và cộng sự 2020b).

- Hiện nay, Việt Nam đã xây dựng Bộ nguyên tắc QLRBV gồm 10 nguyên tắc, 56 tiêu chí và 207 chỉ tiêu, bộ tiêu chuẩn quốc gia về quản lý rừng bền vững và chứng chỉ rừng ở Việt Nam theo PEFC. Về diện tích rừng được cấp chứng chỉ: Đến ngày 2/11/2017 nước ta đã có 29 đơn vị được cấp chứng chỉ rừng với tổng diện tích là 218.065ha. Như vậy, so với chỉ tiêu đề ra trong Chiến lược phát triển Lâm nghiệp giai đoạn 2006-2020, Đề án tái cơ cấu ngành lâm nghiệp là đến 2020 phải có $30 \%$ diện tích rừng sản xuất được cấp chứng chỉ QLRBV thì đến nay chỉ tiêu này mới đạt khoảng $3,3 \%$. Kết quả này cho thấy với tiến độ như hiện nay thì đến 2020 rất khó để nước ta có thể đạt được chỉ tiêu $30 \%$ diện tích rừng sản xuất được cấp chứng chỉ QLRBV (Trần 2020).

- Theo kết quả phỏng vấn với các chuyên gia, việc không đạt được mục tiêu về chứng chỉ rừng là do sự không rõ ràng về quyền sử dụng đất, chi phí thẩm định cao, khó khăn đối với người dân và doanh nghiệp trong việc tiếp cận với nguồn vốn, giá cả và thị trường chưa ổn định và đảm bảo.

Trồng rừng mới (triệu ha)

Trồng lại rừng sau khai thác (triệu ha/năm)
Mặc dù Chiến lược đặt mục tiêu giảm sự lệ thuộc vào nhập khẩu gỗ quốc tế (từ 80\% xuống 20\%) nào năm 2020 bằng cách mở rộng diện tích rừng trồng, phát triển rừng và khu bảo vệ nội địa để thay thế nhập khẩu, cấp phép cho $30 \%$ rừng sản xuất quốc gia và phát triển, nâng cấp ngành công nghiệp chế biến phục vụ xuất khẩu, theo Phạm và cộng sự (2012) tổng hợp điều này rất khó khăn bởi các lí do sau:

- Việc duy trì và/hoặc mở rộng diện tích rừng đòi hỏi phải ổn định quy hoạch sử dụng đất nhưng việc chuyển đổi đất không theo quy hoạch sang các mục đích khác, (ví dụ như để phát triển nông nghiệp và cơ sở hạ tầng) dẫn đến nguy cơ kế hoạch này khó có thể hoàn thành. 
Bảng 2. Tiếp trang trước

\section{Mục tiêu, nhiệm vụ không đạt mục tiêu đề ra}

\section{Lí do không đạt được mục tiêu}

- Ngành công nghiệp chế biến gỗ nội địa gặp trở ngại bởi ngành dăm gỗ khá cạnh tranh, chi phí vận tải để chuyển gỗ từ rừng tới các nhà máy cao, bộ máy quản lí quan liêu và kém hiệu quả, diện tích đất manh mún, và nhiều hộ gia đình nhỏ lẻ quản lý

- Hợp tác, liên kết giữa các doanh nghiệp còn rất hạn chế và thiếu tín dụng hỗ trợ và các chính sách đầu tư. Hơn nữa, sản xuất nội địa yêu cầu một khối lượng lớn gỗ nhập khẩu trong khi yêu cầu ràng buộc pháp lý và gỗ nhập khẩu trên thị trường ngày càng cao.

- Các rừng trồng hiện nay chỉ có khả năng cung cấp các loại gỗ có đường kính nhỏ do vậy chỉ phục vụ công nghiệp chế biến dăm bào, trong khi đó ngành công nghiệp đồ gỗ gia dụng lại đòi hỏi gỗ có đường kính lớn.

- Trồng rừng nói chung không được coi như là một ngành kinh doanh dễ tồn tại, chủ yếu là vì sự hiểu biết về gỗ và lâm sản và cách thức tạo doanh thu và lợi ích từ trồng rừng còn hạn chế. Thêm vào đó, việc cung lớn hơn cầu của gỗ cho công nghiệp giấy và bột giấy dẫn đến giá của các sản phẩm này ngày càng thấp

- Hiện nay, các cơ quan lâm nghiệp và các doanh nghiệp tư nhân là hai nhóm duy nhất đầu tư vào trồng rừng. Hơn nữa, việc có nhiều trung gian tham gia vào thương mại gỗ sẽ đẩy chi phí giao dịch lên cao và các bên buộc phải chấp nhận giá thấp; vì vậy thu nhập không đáng kể, làm cho việc tích tụ vốn để tiếp tục tái trồng rừng là không khả thi.

\section{Khoanh nuôi tái sinh rừng (triệu ha/năm)}

Theo các bên phỏng vấn, việc không đạt mục tiêu diện tích khoanh nuôi tái sinh rừng là do nhiều nguyên nhân:

- Mức hỗ trợ đầu tư khoanh nuôi tái sinh rừng thấp. Do ngân sách hạn hẹp nên công tác khoanh nuôi tái sinh rừng tập trung chủ yếu vào rừng phòng hộ và đặc dụng là chủ yếu mà chưa hỗ trợ hiệu quả với diện tích rừng sản xuất.

- Công tác vận động người dân đặc biệt ở những vùng dân tộc thiểu số có truyền thống canh tác lúa nương đăng kí khoanh nuôi tái sinh rừng rất khó khăn. Người dân không muốn khoanh nuôi tái sinh rừng từ diện tích đất nương họ đang canh tác, bởi làm nương thì có giá trị thu nhập cao hơn và cũng là văn hóa của nhiều dân tộc.

- Mặc dù Trung ương có cấp kinh phí cho khoanh nuôi tái sinh rừng nhưng nhiều tỉnh trong thực tế không có nguồn kinh phí đối ứng cho hạng mục lập hồ sơ giao khoán và chi phí quản lí để thực hiện hoạt động này

- Năng lực cán bộ địa phương thường hạn chế do vậy thường phải thuê tư vấn lập hồ sơ giao khoán. Nhưng do mức chi trả và nguồn kinh phí hạn hẹp nên thường khó tìm được tư vấn thực hiện đúng hạn

- Khoanh nuôi tái sinh rừng chủ yếu tập trung ở các rừng trên cạn trong khi diện tích và chất lượng khoanh nuôi tái sinh rừng đối với rừng ngập mặn rất hạn chế
Theo kết quả phỏng vấn với các chuyên gia, tại nhiều địa phương trên cả nước, công tác trồng cây phân tán đã được tuyên truyền rộng rãi và nhiều hoạt động đã được tiến hành. Tuy nhiên, nguồn vốn phân bổ không đáp ứng được với nhu câu thực tế, chất lượng cây giống không đảm bảo và quy hoạch chưa phù hợp là nhứng nguyên nhân chính dẫn đến việc mục tiêu trồng cây phân tán chưa đạt được

Theo các bên phỏng vấn, chưa đạt được mục tiêu về sản lượng gỗ lớn là do các nguyên nhân sau:

- Nhiêu địa phương chưa tích cực chỉ đạo trồng thâm canh và chuyển hóa rừng trồng kinh doanh gỗ lớn. 
Bảng 2. Tiếp trang trước

\begin{tabular}{ll}
\hline $\begin{array}{l}\text { Mục tiêu, nhiệm vụ không đạt } \\
\text { mục tiêu đề ra }\end{array}$ & Lí do không đạt được mục tiêu \\
\hline • Nhiều địa phương chưa cân đối được ngân sách để có thể có chính sách \\
hỗ trợ kịp thời người dân tham gia trồng rừng gỗ lớn. Tuy nhiên, ngay cả \\
tại các tỉnh đã có nguồn kinh phí này thì người dân ở nơi có địa hình và \\
thời tiết khắc nghiệt với gió bão cấp độ lớn không muốn tham gia và phát \\
triển vào mô hình trồng rừng gỗ lớn do rủi ro cao \\
- Thiếu các nghiên cứu khoa học cơ bản và tuyển tập các loài cây phù hợp \\
với các vùng sinh thái cụ thể, có khả năng tăng trưởng nhanh, tạo sinh \\
khối lớn và có năng suất chất lượng cao. \\
- Thiếu các mô hình sinh kế hiệu quả giúp người dân đảm bảo sinh kế trong \\
một chu kì sản xuất gỗ lớn thường rất dài
\end{tabular}

Gỗ củi cho khu vực nông thôn (triệu $\mathrm{m}^{3} /$ năm).
Hiện nay chưa có báo cáo hay phân tích nào phân tích cụ thể về việc mục tiêu gỗ củi cho nông thôn chưa đạt được. Tuy nhiên, tại thời điểm xây dựng Chiến lược 2006- 2020, gỗ củi được xác định là nguyên nhân chính dẫn đến phá rừng và suy thoái rừng vì người dân chủ yếu dùng gỗ củi cho nhu cầu đun nấu và đảm bảo năng lượng. Tuy nhiên, với sự phát triển của xã hội ngày nay, người dân nông thôn đã chuyển sang dùng loại hình đun nấu khác ví dụ bếp gas, biogas, bếp cải tiến nên nhu cầu và việc sử dụng gỗ củi đã giảm mạnh.

Thu từ DVMTR (tỷ USD)

- Chưa bao gồm chi trả trực tiếp và thuê dịch vụ môi trường rừng (MTR)
- Khái niệm về giá rừng dựa trên giá trị quyền sử dụng rừng, quyền sử hữu rừng là khái niệm hẹp và chỉ bao gồm các lợi ích trực tiếp từ việc sử dụng lâm sản theo quy định hiện hành. Khái niệm này chưa tiếp cận theo quan điểm tổng giá trị kinh tế của rừng, do đó các giá trị dịch vụ môi trường rừng chưa được đề cập trong giá rừng. Ngoài ra tổ chức thực hiện và giám sát định giá rừng chưa được quan tâm đúng mức ở cả cấp trung ương và địa phương. Việc áp dụng khung giá rừng do tỉnh đưa ra cũng gặp nhiều khó khăn bao gồm: (1) khung giá được ban hành không thể hiện được giá trị của rừng tại thời điểm ban hành do việc ban hành văn bản thường ra chậm từ 1-2 năm so với báo cáo đề xuất khung giá; (2) các cơ quan áp dụng tính giá rừng dựa trên các định mức về giá do Sở tài chính đưa ra và chưa phản ánh thị trường; (3) năng lực thực hiện định giá rừng còn hạn chế ở địa phương và (4) khung giá rừng chủ yếu được hình thành thông qua các cơ quan quản lý Nhà nước, do đó giá rừng có thể sẽ không phản ánh đúng quy luật thị trường.Báo cáo cũng đề xuất rằng lồng ghép định giá dịch vụ môi trường rừng trong chính sách lâm nghiệp cần dựa trên 4 nguyên tắc chính: (i) Các dịch vụ môi trường cần được đánh giá thông qua góc nhìn đa mục đích và với cả giá trị từ gỗ và ngoài gỗ và trong bối cảnh sự đóng góp của rừng và các ngành lâm nghiệp để tăng trưởng xanh (ii) định giá dịch vụ môi trường rừng cần phải được gắn vào các chính sách lâm nghiệp để khuyến khích việc sử dụng rừng đa mục đích và các chủ rừng cần được khuyến khích hoặc thậm chí đền bù để cung cấp và đảm bảo việc sử dụng rừng đa mục đích; (iii) định giá dịch vụ môi trường cần được dựa trên cả phương pháp tính toán khoa học và tham vấn cộng đồng về vai trò và tác động của dịch vụ môi trường đến việc sử dụng đất hiện tại và tương lai cũng như sinh kế địa phương (iv) việc xem xét sự hài hòa giữa các dịch vụ môi trường khác nhau quan trọng hơn đánh giá kinh tế của từng dịch vụ đơn lẻ (Phạm và cộng sự 2017, Phương và cộng sự 2017). 
Bảng 3. Kết quả thực hiện theo vùng sinh thái về phát triển ngành chế biến lâm sản

\begin{tabular}{|c|c|c|c|c|c|c|}
\hline \multirow[b]{2}{*}{$\begin{array}{l}\text { Các vùng } \\
\text { sinh thái }\end{array}$} & \multirow[b]{2}{*}{ Mục tiêu } & \multicolumn{5}{|c|}{ Kết quả } \\
\hline & & DN CBG & $\begin{array}{l}\text { Theo khu vực } \\
\text { kinh tế }\end{array}$ & $\begin{array}{l}\text { Theo quy } \\
\text { mô }\end{array}$ & $\begin{array}{c}\text { Theo sản phẩm sản } \\
\text { xuất }\end{array}$ & $\begin{array}{l}\text { Tỷ lệ tăng } \\
\text { trưởng } \\
\text { trung bình } \\
\text { 2015-2018 }\end{array}$ \\
\hline $\begin{array}{l}\text { Vùng trung } \\
\text { du và miền } \\
\text { núi Bắc Bộ }\end{array}$ & & $\begin{array}{l}718 \text { DN } \\
\text { CBG } \\
\text { (chiếm } \\
7,04 \% \\
\text { so với cả } \\
\text { nước) }\end{array}$ & $\begin{array}{l}1 \text { DN nhà nước } \\
705 \text { DN ngoài } \\
\text { nhà nước } \\
12 \text { DN vốn dầu } \\
\text { tư nước ngoài } \\
\text { (FDI) }\end{array}$ & $\begin{array}{l}11 \mathrm{DN} \text { lớn } \\
363 \mathrm{DN} \text { vừa } \\
\text { và nhỏ } \\
344 \mathrm{DN} \\
\text { siêu nhỏ }\end{array}$ & $\begin{array}{l}356 \text { DN sản xuất ván } \\
\text { nhân tạo, gỗ xây } \\
\text { dựng } \\
280 \text { DN gia công và } \\
\text { bảo quản gỗ tự nhiên } \\
82 \text { DN sản xuất đồ } \\
\text { mộc nội thất (giường, } \\
\text { tủ, bàn ghế) }\end{array}$ & 3,76\%/ năm \\
\hline $\begin{array}{l}\text { Vùng đồng } \\
\text { bằng Bắc Bộ }\end{array}$ & $\begin{array}{l}\text { Phát triển } \\
\text { công nghiệp } \\
\text { chế biến gỗ } \\
\text { và LSNG, các } \\
\text { làng nghể } \\
\text { truyền thống }\end{array}$ & $\begin{array}{l}2.987 \\
\text { DN CBG } \\
(27,24 \% \\
\text { so với cả } \\
\text { nước) }\end{array}$ & $\begin{array}{l}1 \text { DN nhà nước } \\
2.942 \text { DN ngoài } \\
\text { nhà nước } \\
44 \text { DN vốn FDI }\end{array}$ & $\begin{array}{l}43 \text { DN lớn } \\
1.604 \text { DN } \\
\text { vừa và nhỏ } \\
1.340 \text { DN } \\
\text { siêu nhỏ }\end{array}$ & $\begin{array}{l}\text { 1.418 DN sản xuất } \\
\text { ván nhân tạo, gỗ xây } \\
\text { dựng } \\
312 \text { DN gia công và } \\
\text { bảo quản gỗ tự nhiên } \\
\text { 1.257 DN sản xuất đồ } \\
\text { mộc nội thất (giường, } \\
\text { tủ, bàn ghế) }\end{array}$ & 7,85\%/ năm \\
\hline $\begin{array}{l}\text { Vùng Bắc } \\
\text { Trung Bộ và } \\
\text { Duyên hải } \\
\text { Nam Trung } \\
\text { Bộ }\end{array}$ & $\begin{array}{l}\text { Phát triển } \\
\text { công nghiệp } \\
\text { chế biến lâm } \\
\text { sản }\end{array}$ & $\begin{array}{l}1.891 \\
\text { DN CBG } \\
(17,6 \% \\
\text { so với cả } \\
\text { nước) }\end{array}$ & $\begin{array}{l}3 \text { DN nhà nước } \\
1.856 \text { DN ngoài } \\
\text { nhà nước } \\
32 \text { DN vốn FDI }\end{array}$ & $\begin{array}{l}85 \text { DN lớn } \\
862 \text { DN vừa } \\
\text { và nhỏ } \\
944 \text { DN } \\
\text { siêu nhỏ }\end{array}$ & $\begin{array}{l}626 \text { DN sản xuất ván } \\
\text { nhân tạo, gỗ xây } \\
\text { dựng } \\
1891 \text { DN gia công và } \\
\text { bảo quản gỗ tự nhiên } \\
615 \text { DN sản xuất đồ } \\
\text { mộc nội thất (giường, } \\
\text { tủ, bàn ghế) }\end{array}$ & 6,26\%/ năm \\
\hline $\begin{array}{l}\text { Vùng Tây } \\
\text { Nguyên }\end{array}$ & $\begin{array}{l}\text { Phát triển chế } \\
\text { biến lâm sản }\end{array}$ & $\begin{array}{l}331 \text { DN } \\
\text { CBG } \\
(3,23 \% \\
\text { so với cả } \\
\text { nước) }\end{array}$ & $\begin{array}{l}2 \text { DN nhà nước } \\
329 \text { DN ngoài } \\
\text { nhà nước }\end{array}$ & $\begin{array}{l}6 \mathrm{DN} \text { lớn } \\
113 \mathrm{DN} \text { vừa } \\
\text { và nhỏ } \\
212 \mathrm{DN} \\
\text { siêu nhỏ }\end{array}$ & $\begin{array}{l}125 \text { DN sản xuất ván } \\
\text { nhân tạo, gỗ xây } \\
\text { dựng } \\
331 \text { DN gia công và } \\
\text { bảo quản gỗ tự nhiên } \\
80 \text { DN sản xuất đồ } \\
\text { mộc nội thất } \\
\text { (giường , tủ, bàn ghế) }\end{array}$ & 5\%/ năm \\
\hline $\begin{array}{l}\text { Vùng Đông } \\
\text { Nam Bộ }\end{array}$ & $\begin{array}{l}\text { Phát triển } \\
\text { công nghiệp } \\
\text { chế biến lâm } \\
\text { sản và xuất } \\
\text { khẩu }\end{array}$ & $\begin{array}{l}4.861 \\
\text { DN CBG } \\
\text { (40,21\% } \\
\text { so với cả } \\
\text { nước) }\end{array}$ & $\begin{array}{l}9 \text { DN nhà nước } \\
4.456 \text { DN ngoài } \\
\text { nhà nước } \\
396 \text { DN vốn FDI }\end{array}$ & $\begin{array}{l}391 \text { DN lớn } \\
2.420 \text { DN } \\
\text { vừa và nhỏ } \\
2.050 \text { DN } \\
\text { siêu nhỏ }\end{array}$ & $\begin{array}{l}475 \text { DN sản xuất ván } \\
\text { nhân tạo, gỗ xây } \\
\text { dựng } \\
3.991 \text { DN gia công và } \\
\text { bảo quản gỗ tự nhiên } \\
1.180 \text { DN sản xuất đồ } \\
\text { mộc nội thất (giường, } \\
\text { tủ, bàn ghế) }\end{array}$ & 12,28\%/ năm \\
\hline $\begin{array}{l}\text { Vùng Đồng } \\
\text { bằng Sông } \\
\text { Cửu Long }\end{array}$ & & $\begin{array}{l}543 \text { DN } \\
\text { CBG } \\
(4,67 \% \\
\text { so với cả } \\
\text { nước) }\end{array}$ & $\begin{array}{l}1 \text { DN nhà nước } \\
520 \text { DN ngoài } \\
\text { nhà nước } \\
22 \text { DN vốn FDI }\end{array}$ & $\begin{array}{l}20 \text { DN lớn } \\
243 \text { DN vừa } \\
\text { và nhỏ } \\
289 \text { DN } \\
\text { siêu nhỏ }\end{array}$ & $\begin{array}{l}82 \text { DN sản xuất ván } \\
\text { nhân tạo, gỗ xây } \\
\text { dựng } \\
543 \text { DN gia công và } \\
\text { bảo quản gỗ tự nhiên } \\
211 \text { DN sản xuất đồ } \\
\text { mộc nội thất (giường, } \\
\text { tủ, bàn ghế) }\end{array}$ & 10,46\%/năm \\
\hline
\end{tabular}


Bảng 4. Mục tiêu và kết quả thực hiện các mục tiêu môi trường

\begin{tabular}{|c|c|c|c|c|c|c|c|c|}
\hline \multirow{2}{*}{\multicolumn{2}{|c|}{ TT }} & \multirow[b]{2}{*}{ Mục tiêu, nhiệm vụ } & \multirow[b]{2}{*}{ Năm 2006} & \multirow[b]{2}{*}{$\begin{array}{l}\text { Mục tiêu } \\
\text { chiến lược } \\
\text { (QĐ 18) }\end{array}$} & \multirow[b]{2}{*}{$\begin{array}{l}\text { Mục tiêu } \\
\text { điều chỉnh }\end{array}$} & \multirow[b]{2}{*}{$\begin{array}{l}\text { Kết quả } \\
\text { thực hiện } \\
2020\end{array}$} & \multicolumn{2}{|c|}{ Đánh giá } \\
\hline & & & & & & & $\begin{array}{l}\text { So với mục } \\
\text { tiêu } C L\end{array}$ & $\begin{array}{l}\text { So với mục } \\
\text { tiêu điều } \\
\text { chỉnh }\end{array}$ \\
\hline 1 & & $\begin{array}{l}\text { Quản lý, bảo vệ, phát } \\
\text { triển } 3 \text { loại rừng (tr ha) }\end{array}$ & & 14,6 & $14,4^{1}$ & $14,6^{2}$ & Không & Đạt \\
\hline \multicolumn{2}{|l|}{2} & Tỷ lệ che phủ rừng (\%) & 37,7 & 47 & $\begin{array}{c}42^{3} \\
44-45^{4}\end{array}$ & 42 & Không & Đạt \\
\hline \multicolumn{2}{|l|}{3} & $\begin{array}{l}\text { Trồng rừng phòng hộ, } \\
\text { đặc dụng (tr.ha) }\end{array}$ & & 0,25 & $\begin{array}{l}0,075 \\
(2016- \\
2020)^{5}\end{array}$ & $0,69^{6}$ & Đạt & Đạt \\
\hline 4 & & $\begin{array}{l}\text { Giảm thấp nhất các } \\
\text { vụ vi phạm quy định } \\
\text { pháp luật bảo vệ phát } \\
\text { triển rừng. }\end{array}$ & 38.534 & Giảm 80\% & $\begin{array}{l}\text { Giảm } \\
30-35 \% \\
\text { so } 2011- \\
2015^{7}\end{array}$ & 10.731 & Không & Đạt \\
\hline \multicolumn{9}{|c|}{ Quyết định số 886/QĐ-TTg ngày 16/6/2017 phê duyệt Chương trình mục tiêu phát triển Lâm nghiệp bền vững giai đoạn } \\
\hline 20 & \multicolumn{8}{|c|}{ Quyết định số công bố hiện trạng rừng toàn quốc năm 2019.} \\
\hline \multicolumn{9}{|c|}{$\begin{array}{l}\text { Quyết định số 886/QĐ-TTg ngày 16/6/2017 phê duyệt Chương trình mục tiêu phát triển Lâm nghiệp bền vững giai đoạn } \\
\text { 2016-2020. }\end{array}$} \\
\hline 4 & \multicolumn{8}{|c|}{$\begin{array}{l}\text { Quyết định số 57/QĐ-TTg ngày 09/01/2012 của Thủ tướng Chính phủ về phê duyệt Kế hoạch bảo vệ và phát triển rừng giai đoạn } \\
\text { 2011-2020, theo đó trồng mới 0,125 triệu ha/năm, trong đó RSX 0,1 tr ha, RPH, ĐD 0,025tr. ha/năm. }\end{array}$} \\
\hline \multicolumn{9}{|c|}{$\begin{array}{l}\text { Quyết định số 886/QĐ-TTg ngày 16/6/2017 phê duyệt Chương trình mục tiêu phát triển Lâm nghiệp bền vững giai đoạn } \\
\text { 2016-2020. }\end{array}$} \\
\hline $\begin{array}{ll}6 & E \\
r \\
2\end{array}$ & \multicolumn{8}{|c|}{$\begin{array}{l}\text { Đến năm 2010, cả nước đã trồng được } 79.810 \text { ha RĐD và đến } 2019 \text { diện tích RT là RĐD đạt } 86.570 \text { ha. Đối với RPH, diện tích RT } \\
\text { năm } 2010 \text { là } 614.265 \text { ha và năm } 2019 \text { là } 692.730 \text { ha. Như vậy, tổng diện tích RT là RĐD và RPH đến năm } 2010 \text { là } 779.300 \text { ha và năm } \\
2019 \text { là } 694.075 \text { ha; vượt mục tiêu của Chiến lược }\end{array}$} \\
\hline \multicolumn{9}{|c|}{$\begin{array}{l}\text { Quyết định số 886/QĐ-TTg ngày 16/6/2017 phê duyệt Chương trình mục tiêu phát triển Lâm nghiệp bền vững giai đoạn } \\
\text { 2016-2020. }\end{array}$} \\
\hline
\end{tabular}

Việc thực hiện các mục tiêu chiến lược phát triển lâm nghiệp 2006-2020 còn thông qua định hướng về phát triển tỉ lệ che phủ rừng và diện tích rừng cho từng vùng sinh thái (Bảng 5 ). Kết quả Bảng 5 cho thấy trong giai đoạn 2006-2019, 4 chỉ tiêu bao gồm diện tích rừng, diện tích rừng trông, rừng tự nhiên, tỷ lệ che phủ rừng đạt được dấu ấn tăng trưởng tích cực ở Vùng Tây Bắc, Đông Bắc, Bắc Trung Bộ và Duyên hải Nam trung bộ nhưng lại tăng trưởng âm đối với Vùng vùng Tây Nguyên, Đông bằng Bắc Bộ và Đông bằng sông Cửu Long. Đối với vùng Đông bằng Bắc Bộ và Đông bằng sông Cửu Long, tỷ lệ che phủ rừng bị giảm chủ yếu do chuyển đổi mục đích sử dụng rừng sang các mục đích khác phục vụ phát triển KT-XH. Đặc biệt vùng Tây Nguyên, việc chuyển đổi mục đích sử dụng rừng, tranh chấp đất đai và vi phạm quy định về quản lý đất lâm nghiệp còn phức tạp; việc trông rừng khó cạnh tranh về hiệu quả kinh tế so với các loại cây trông khác. Điều nay cho thấy cần có những thay đổi về mặt chính sách cụ thể để có thể việc quản lí bảo vệ rừng tại vùng trọng điểm này được hiệu quả hơn.

\subsection{Xã hội}

Chiến lược lâm nghiệp giai đoạn 2006-2020 đặt ra 4 mục tiêu xã hội nhửng chỉ có 1 mục tiêu liên quan đến tạo việc làm là đạt và vượt chỉ tiêu, 3 mục tiêu còn lại đều không đạt được, kể cả so với các chỉ tiêu đã điều chỉnh (Bảng 6).

Các mục tiêu xóa đói và giảm số hộ nghèo không đạt được có nhiều nguyên nhân. Tuy nhiên theo như Phạm và cộng sự (2010), một trong những nguyên nhân chính là mặc dù đã có nhiều chương trình của nhà nước hỗ trợ người nghèo nhưng không phải hộ nghèo nào cũng có đủ điều kiện về nguồn lực tài chính và con người để tham gia. Việc thực hiện cơ chế chia sẻ lợi ích của 
Bảng 5. Kết quả thực hiện về diện tích và tỉ lệ che phủ rừng theo các vùng sinh thái Rừng 2006-2019

\begin{tabular}{|c|c|c|c|c|c|}
\hline \multicolumn{2}{|c|}{ Các vùng sinh thái } & Tiêu chí & 2006 & 2019 & 2006-2019 \\
\hline \multirow{8}{*}{$\begin{array}{l}\text { Vùng } \\
\text { trung du } \\
\text { miền núi } \\
\text { phía Bắc }\end{array}$} & \multirow[t]{4}{*}{ Tây Bắc } & Diện tích rừng (ha) & 1.508 .740 & 1.757 .428 & 248.688 \\
\hline & & Rừng trông (ha) & 109.573 & 195.379 & 85.806 \\
\hline & & Rừng tự nhiên (ha) & 1.399.167 & 1.562 .049 & 162.882 \\
\hline & & Tỷ lệ che phủ rừng (\%) & 40,33 & 45,52 & 5,19 \\
\hline & \multirow[t]{4}{*}{ Đông Bắc } & Diện tích rừng (ha) & 3.164 .871 & 3.925 .225 & 760.354 \\
\hline & & Rừng trông (ha) & 893.874 & 1.560 .149 & 666.275 \\
\hline & & Rừng tự nhiên (ha) & 2.270 .997 & 2.365 .076 & 94.079 \\
\hline & & Tỷ lệ che phủ rừng (\%) & 47,93 & 56,28 & 8,35 \\
\hline \multirow{4}{*}{\multicolumn{2}{|c|}{ Đồng bằng Bắc Bộ }} & Diện tích rừng (ha) & 95.836 & 82.775 & -13.061 \\
\hline & & Rừng trồng (ha) & 48.520 & 36.676 & 11.844 \\
\hline & & Rừng tự nhiên (ha) & 47.316 & 46.099 & 1.217 \\
\hline & & Tỷ lệ che phủ rừng (\%) & 8,18 & 6,04 & $-2,14$ \\
\hline \multirow{8}{*}{$\begin{array}{l}\text { Vùng Bắc } \\
\text { Trung Bộ và } \\
\text { duyên hải } \\
\text { Nam Trung } \\
\text { Bộ }\end{array}$} & \multirow[t]{4}{*}{ Bắc Trung Bộ } & Diện tích rừng (ha) & 2.611 .526 & 3.116 .921 & 505.395 \\
\hline & & Rừng trồng (ha) & 534.584 & 900.466 & 365.882 \\
\hline & & Rừng tự nhiên (ha) & 2.076 .942 & 2.216 .455 & 139.513 \\
\hline & & Tỷ lệ che phủ rừng (\%) & 50,73 & 57,76 & 7,03 \\
\hline & \multirow{4}{*}{$\begin{array}{l}\text { Duyên hải } \\
\text { Nam Trung Bộ }\end{array}$} & Diện tích rừng (ha) & 1.775 .779 & 2.436 .689 & $660.919^{1}$ \\
\hline & & Rừng trồng (ha) & 330.914 & 862.189 & 531.275 \\
\hline & & Rừng tự nhiên (ha) & 1.444 .856 & 1.574 .500 & 129.644 \\
\hline & & Tỷ lệ che phủ rừng (\%) & 40,57 & 50,35 & 9,78 \\
\hline \multirow{4}{*}{\multicolumn{2}{|c|}{ Tây Nguyên }} & Diện tích rừng (ha) & 2.976 .950 & 2.559 .956 & -416.994 \\
\hline & & Rừng trồng (ha) & 152.115 & 368.734 & 216.619 \\
\hline & & Rừng tự nhiên (ha) & 2.824 .835 & 2.191 .222 & -633.613 \\
\hline & & Tỷ lệ che phủ rừng (\%) & 54,66 & 45,92 & $-8,74^{2}$ \\
\hline \multirow{4}{*}{\multicolumn{2}{|c|}{ Đông Nam Bộ }} & Diện tích rừng (ha) & 431.137 & 480.892 & 49.755 \\
\hline & & Rừng trồng (ha) & 144.942 & 223.735 & 78.793 \\
\hline & & Rừng tự nhiên (ha) & 286.195 & 257.157 & $-29,038$ \\
\hline & & Tỷ lệ che phủ rừng (\%) & 18,23 & 19,37 & 1,14 \\
\hline \multirow{4}{*}{\multicolumn{2}{|c|}{ Đồng bằng sông Cửu Long }} & Diện tích rừng (ha) & 309.307 & 249.335 & -59.702 \\
\hline & & Rừng trông (ha) & 248.992 & 169.459 & -79.533 \\
\hline & & Rừng tự nhiên( ha) & 60.045 & 79.876 & 19.831 \\
\hline & & Tỷ lê che phủ rừng (\%) & 8,25 & 5,4 & $-2,85$ \\
\hline
\end{tabular}

1 Đây là vùng có diện tích rừng tăng nhiều nhất trong 15 năm qua: trong đó, rừng trồng tăng gấp 2,55 lần so với rừng tự nhiên.

2 Giảm nhiêu nhất trong cả nước

Nguồn: Tác giả tổng hợp từ số liệu do Tổng cục Lâm nghiệp cung cấp 2020 
Bảng 6. Mục tiêu xã hội và kết quả thực hiện

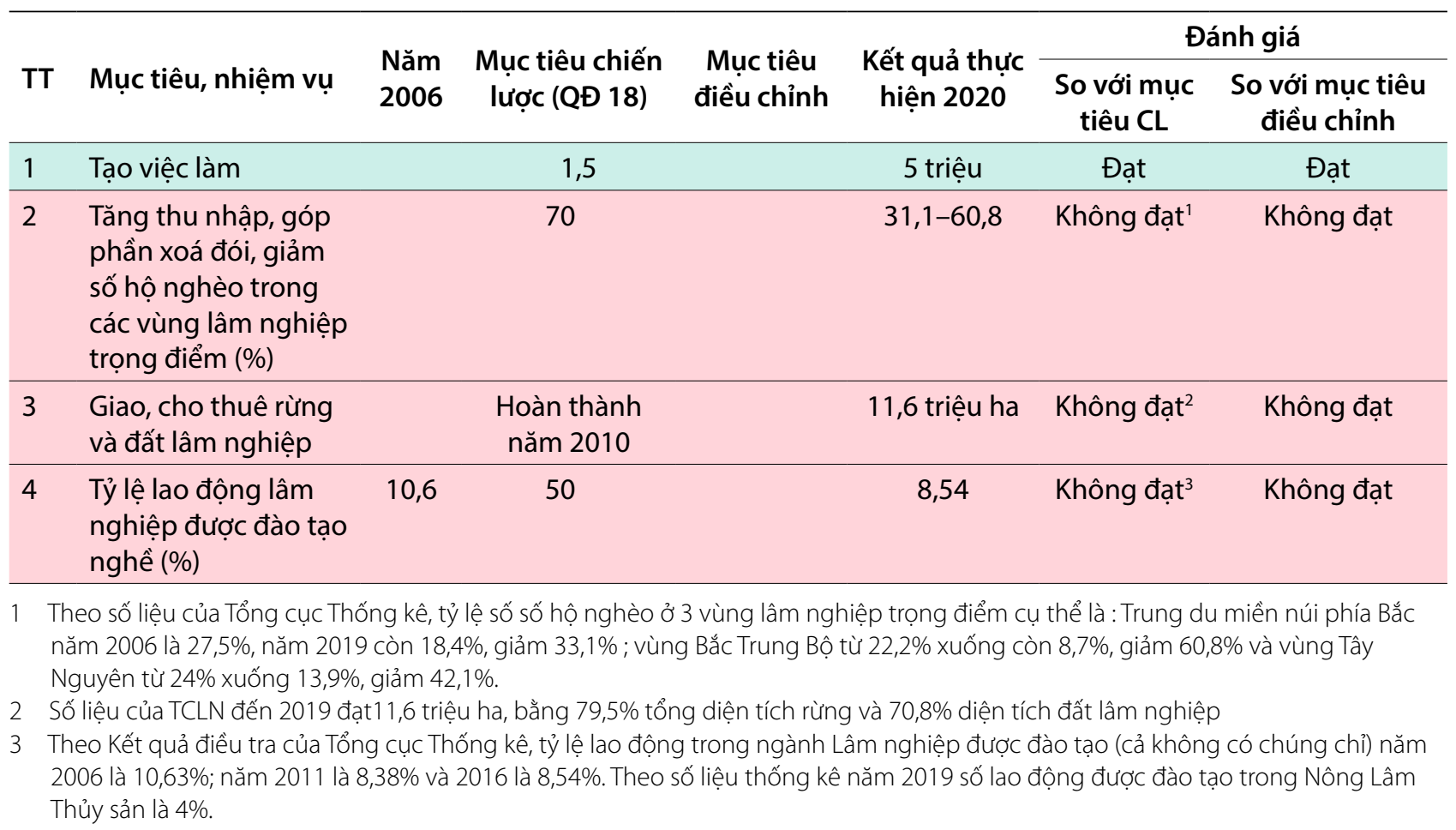

Nguồn: Tác giả tổng hợp từ tài liệu của TCLN, 2020

các chương trình này không hiệu quả và công bằng cũng dẫn tới việc người dân không được tiếp cận thông tin và các hỗ trợ của những dự án, chương trình bảo vệ rừng đây đủ (Phạm và cộng sự 2011, Phạm và cộng sự 2019c). Ngoài ra, người nghèo thường ít tiếp cận với thị trường, trong khi nhu cầu lao động ngày càng tăng, các công nghệ ngày càng tân tiến và các phương tiện chế biến công nghiệp ngày càng tập trung hoá. Việc tiếp cận thông tin của người nghèo với các chương trình chính sách của nhà nước còn hạn chế do truyền thông và kết nối thông tin giữa các bên kém hiệu quả (Moeliono và cộng sự 2016).

Đối với chương trình giao đất giao rừng, việc không đạt được mục tiêu đề ra cũng được tổng hợp và lí giải trong báo cáo của Phạm và cộng sự (2012) và Phạm và cộng sự (2016a)

(Xin xem thêm Hộp 2).

Lí giải cho việc mục tiêu về đào tạo nguôn nhân lực cho ngành không đạt được, các bên phỏng vấn cho rằng mặc dù các hệ thống trường đại học và cao đẳng lâm nghiệp đã có nhiều đổi mới, cạnh tranh với các ngành nghể khác cũng như hiện nay các chương trình giảng dạy chưa đi kịp với thời đại đã khiến việc tuyển dụng sinh viên cho ngành lâm nghiệp trở nên khó khăn hơn. Phạm và cộng sự (2012) cũng chỉ ra rằng, các chương trình đào tạo không đáp ứng được các nhu cầu thực tiễn của thị trường và địa phương. Đối với những thách thức về đảm bảo nguồn nhân lực, Trần (2020) cũng giải thích những khó khăn bao gồm:

- Số lượng, năng lực và trình độ của đội ngũ cán bộ quản lý, cán bộ khoa học kỹ thuật của ngành chưa đáp ứng yêu câu khi bước vào cơ chế thị trường và hội nhập quốc tế

- Bố trí lực lượng cán bộ mất cân đối giữa khâu bảo vệ và phát triển rừng làm giảm hiệu lực và hiệu quả của bộ máy quản lý, nhất là ở cấp huyện và xã

- Đối với nguồn nhân lực cho sản xuất kinh doanh lâm nghiệp, hiện tại thiếu trầm trọng công nhân có tay nghề cao, kỹ sư giỏi trong lĩnh vực chế biến lâm sản và sản xuất cây giống chất lượng cao, trình độ đào tạo chưa tương xứng với bằng cấp đào tạo.

- Sự gắn kết giữa các đơn vị đào tạo, nghiên cứu và khuyến lâm lỏng lẻo, thiếu cơ chế hợp tác chặt chẽ, các chương trình giáo dục, đào tạo và khuyến không thực hiện tốt hoạt động đánh giá nhu câu đào tạo, nội dung và phương pháp đào tạo chưa theo kịp với yêu câu thực tế. 


\section{Hộp 2. Nguyên nhân chính dẫn đến thách thức trong việc giao đất và giao rừng tại Việt Nam}

- Địa hình khó khăn, thiếu kinh phí và nhân sự để thực hiện đo đạc cần thiết để cấp Sổ đỏ; bản đồ đất đai cũ, ranh giới giữa các loại đất không rõ ràng, dẫn đến tình trạng nhiều giấy chứng nhận đất lâm nghiệp không khớp với diện tích đang được quản lý, vì các cơ quan sử dụng các số liệu hay phương pháp đo diện tích khác nhau.

- Sự khác biệt giữa các quy định chính sách, pháp luật và tục lệ truyền thống cũng như hiệu lực thi hành các quy định pháp luật kém đã gây trở ngại đối với quản lý hiệu quả. Các vấn đề này đã được các bên liên quan biết đến nhưng lại chưa có biện pháp xử lý phù hợp.

- Giao đất lâm nghiệp chưa đảm bảo giao 'thực quyền', tức là quyền pháp quy và trên thực tế có thể tạo ra các điều kiện tiếp cận mở. Đất lâm nghiệp giao thường không mầu mỡ và trong trường hợp không được hỗ trợ tài chính và kỹ thuật của chính phủ thì thường bị bỏ hoang. Đáng lo ngại hơn là, đất mà theo phân loại của chính phủ là 'đất chưa sử dụng' trên thực tế đã có chủ theo phong tục không được pháp luật công nhận chính thức. Ở nhiều địa phương, một số hộ gia đình không muốn nhận đất lâm nghiệp vì diện tích đất đó nằm cách xa nhà của họ gây khó khăn cho việc quản lý, trông nom, bảo vệ. Trong những hoàn cảnh như vậy các hộ gia đình có thể cho các lâm trường quốc doanh thuê lại để nhận mức phí chỉ thấp bằng thuế sử dụng đất.

- Giao đất lâm nghiệp không cho phép đồng sở hữu ở cấp hộ và cộng đồng. Quy định này có thể hạn chế các quyền của phụ nữ và hạn chế hệ thống sản xuất ở vùng cao trên cơ sở các cách tiếp cận đồng sở hữu tài sản.

- Ở cấp tỉnh, quy hoạch sử dụng đất lâm nghiệp thường hay bị thay đổi; điều đó dẫn đến việc các hộ gia đình không thể điều chỉnh kế hoạch của họ kịp thời theo những thay đổi thất thường đó. Do đó, đất bị bỏ hoang, hoặc sử dụng vào các mục đích khác với quy định.

- Người dân địa phương ít khi coi việc thu hoạch có quy mô thương mại là có lợi cho mình, mà họ coi rằng việc này ảnh hưởng tiêu cực đến mô hình quản lý tài nguyên truyền thống của họ. Vi vậy, giao đất dường như không hỗ trợ giảm nghèo vì thu nhập từ bảo vệ rừng và trồng rừng ít khi có đóng góp vào thu nhập của người nghèo vùng cao. Các doanh nghiệp nhà nước và khai thác gỗ thường coi những cây gỗ lớn là tài sản riêng của họ chứ không phải là tài sản của những người sống bằng nghề rừng và sống gần rừng.

- Theo quyết định 187, các lâm trường quốc doanh phải giao lại và hợp đồng đất lâm nghiệp mà họ đang kiểm soát cho các bên thứ ba để sử dụng và bảo vệ lâu dài theo NĐ số 01 của chính phủ; khi đó các bên hợp đồng thứ ba này có thể hưởng lợi từ các lâm sản chính. Tuy nhiên, trên thực tế, các lâm trường quốc doanh thường chỉ hợp đồng với các bên thứ ba với thời hạn hàng năm chứ không phải dài hạn. Tinh hình đó dẫn đến cam kết của các hộ về bảo vệ rừng thấp.

- Vấn đề căn bản nhất là sự bất công bằng, với diện tích đất giao ưu đãi cho các tổ chức đoàn thể, cán bộ nhân viên của các lâm trường quốc doanh và một số cá nhân. Từ đó, đất lâm nghiệp đã trở thành cơ sở để tích luỹ vốn cho các hộ gia đình có quyền lực chính trị và quan hệ xã hội. Bất bình đẳng cũng xảy ra giữa các nhóm dân tộc thiểu số; nhóm người Kinh thường được giao nhiều đất hơn các các nhóm dân tộc thiểu.

- Mặt khác, giao đất lâm nghiệp đã cho phép thu hút các thành phần khác ngoài khu vực nhà nước vào hoạt động quản lý rừng. Gần đây, đã có 8 đối tượng gồm các công ty nhà nước (các lâm trường quốc doanh trước đây), các ban quản lý rừng phòng hộ, các ban quản lý rừng đặc dụng như các khu bảo tồn và vườn quốc gia; các hộ gia đình, cộng đồng thôn bản; các UBND xã; công ty cổ phần; và lực lượng quốc phòng. Tuy nhiên, các công ty nhà nước và các ban quản lý tiếp tục quản lý trên $50 \%$ rừng của quốc gia. Người dân địa phương chỉ được tiếp cận một cách hạn chế rừng phòng hộ và rừng sản xuất.

- Các đơn vị thuộc khu vực nhà nước chiếm giữ các diện tích rừng chất lượng cao nhất, trong khi các thành phần thuộc khu vực ngoài nhà nước, nhất là người dân địa phương được giao rừng với chất lượng kém và suy thoái. Điều này có thể dẫn đến việc khó khăn trong việc huy động các hộ gia đình tham gia vào công tác bảo vệ rừng.

- Giao đất ở Việt Nam chủ yếu dựa vào khả năng đầu tư vào đất bao gồm nhân lực và vốn. Tuy nhiên, đa số người nghèo, kể các người dân tộc thiểu số, trong đó phần lớn phụ thuộc vào rừng, đều thiếu cả lao động và vốn.

- Tại các tỉnh miền núi phía Bắc, thực tế giao đất giao rừng vô cùng khó khăn bởi hệ thống quản lí cơ sở dữ liệu nghèo nàn thiếu chính xác, sự thiếu thống nhất về số liệu giữa các cơ quan nhà nước, số liệu không cập nhật và thiếu nguồn lực và cam kết chính trị trong việc giao đất giao rừng ở những nơi có tranh chấp và xung đột. 
- Đầu tư vào nâng cao năng lực và cơ sở vật chất kỹ thuật cho các đơn vị đào tạo về lâm nghiệp rất hạn chế, chất lượng đào tạo chưa được nâng cao xứng tâm, khó khăn trong cơ chế tuyển dụng và khuyến khích lao động trong ngành Lâm nghiệp đã không thu hút được sinh viên học tập tại các trường đại học và cao đẳng trong ngành. Các ngành đào tạo truyền thống có số lượng người học rất thấp cũng xuất phát từ thực trạng cơ sở vật chất, kỹ thuật, kết cấu chương trình đào tạo và bài giảng chưa đáp ứng được yêu câu thực tiễn, sinh viên tốt nghiệp chưa đảm bảo có được kiến thức và kỹ năng cân thiết của nghề nghiệp.

- Đội ngũ các nhà khoa học và người làm công tác chuyên môn, đặc biệt ở cấp địa phương và cơ sở sản xuất còn thiếu vê số lượng, ở nhiều lĩnh vực còn yếu về số lượng, chưa đông bộ, chưa hình thành các ê-kíp khoa học theo từng lĩnh vực chuyên môn sâu, với các trình độ khác nhau, ít có tính kế thừa, do đó khả năng thu hút kinh phí và thực hiện các chương trình nghiên cứu tổng hợp, có tính liên ngành còn nhiêuu hạn chế.

- Hệ thống khuyến nông-lâm chủ yếu dựa vào nguồn ngân sách và kỹ thuật của nhà nước với cách tiếp cận "từ trên xuống", hệ thống khuyến nông tự nguyện yếu và gần như chưa huy động được sự tham gia của khu vực tư nhân vào hoạt động này. Điều này cũng xuất phát từ nguyên nhân ngành lâm nghiệp là ngành sản xuất vật chất có chu kỳ sản xuất dài, kém hấp dẫn trong đâu tư và rủi ro cao. Trong khi dịch vụ khuyến nông-lâm lại chỉ tập trung vào việc chuyển giao kỹ thuật, chưa thật sự mang lại lợi ích kinh tế trực tiếp cho người dân và khu vực tư nhân trong việc phát triển sản xuất, mở rộng thị trường và nâng cao giá trị tăng thêm cho lâm sản và các sản phẩm nông lâm kết hợp.

- Sự nhìn nhận và đánh giá của các cấp quản lý, người dân và xã hội về vai trò của ngành Lâm nghiệp còn phiến diện, chưa nhìn nhận rõ giá trị và lợi ích mà rừng và ngành lâm nghiệp đóng góp cho xã hội, nền kinh tế và môi trường sinh thái. Việc thiếu các chương trình nghiên cứu toàn diện và khoa học về định giá tài nguyên rừng và các dịch vụ hệ sinh thái rừng mang lại về kinh tế, xã hội và môi trường là một trong những nguyên nhân chủ yếu của thực trạng này. Ngoài ra, việc thực hiện các chính sách trong thực tiễn về chi trả dịch vụ môi trường rừng và $\mathrm{REDD}+$ cũng chưa thật sự tạo ra nguôn tài chính có ý nghĩa đột phá giúp tăng đâu tư vào bảo vệ và phát triển rừng ở Việt Nam.

- Đơn vị một kiểm lâm viên phải thực hiện quản lý bảo vệ diện tích rừng gấp 2 thậm chí 3 lần so với định mức, trong khi còn thiếu cơ chế hỗ trợ và tài chính cho lực lượng bảo vệ rừng chuyên trách ở các đơn vị này. Đặc thù công việc nặng nhọc, nguy hiểm trong khi thu nhập thấp và không ổn định là một trong những nguyên nhân rất khó thu hút người học vào các trường đào tạo về lâm nghiệp.

Một điểm đáng lưu ý là vấn để bình đẳng giới còn chưa được quan tâm đúng mức. Phạm và cộng sự (2012) và Phạm và cộng sự (2016b) chỉ ra rằng, sự tham gia của phụ nữ trong ngành lâm nghiệp rất hạn chế và không thấy bằng chứng vêt sự phối hợp và hỗ trợ hiệu quả của chính quyền địa phương đối với phụ nữ ở các cộng đông. Nhóm tác giả này cũng chỉ ra những thách thức trong việc lông ghép giới khi thiếu cán bộ chuyên môn để thực hiện lồng ghép các vấn đề giới vào các hoạt động lâm nghiệp và một thực tế nữa là phụ nũ ít được bổ nhiệm vào các vị trí lãnh đạo. Ngoài ra, mặc dù chính sách lâm nghiệp đã có nhiều cam kết về vấn đề bình đẳng giới, các chương trình và dự án lại không có hướng dẫn và hệ thống giám sát cụ thể về tiêu chí này (Phạm and Brockhaus 2015). Ngoài ra cơ chế chia sẻ lợi ích và việc cung cấp thông tin về các chương trình dự án bảo vệ rừng rất ít khi xem xét tới nhu cầu và khả năng tiếp cận của phụ nũ (Phạm and Brockhaus 2015). 


\section{Kết quả thực hiện các chương trình}

Như phần trên đã trình bày, việc thực hiện chiến lược được tổ chức qua 6 chương trình và trong phân dưới đây, nhóm tác giả sẽ lần lượt trình bày vể kết quả đạt được của từng chương trình.

\subsection{Chương trình quản lý và phát triển rừng bền vững}

Chương trình quản lí và phát triển rừng bền vững là trụ cột của Chiến lược phát triển ngành lâm nghiệp 2006-2020. Bảng 7 cho thấy Chương trình này đề ra 9 mục tiêu chính nhưng chỉ có $2 / 9$ mục tiêu đã đạt và vượt mục tiêu; $2 / 9$ mục tiêu không có số liệu và hệ thống giám sát để đánh giá và 5 mục tiêu còn lại chỉ đạt được một phần mục tiêu dự kiến. Việc lí giải cho các nguyên nhân cho việc không đạt được các mục tiêu đã được thảo luận và trình bày tại phân Mục tiêu môi trường phía trên. Tuy nhiên, sự thiếu hụt về hệ thống giám sát đánh giá về một số chỉ tiêu về làm giàu rừng hay đầu tư xây dựng hệ thống thông tin cơ sở hạ tâng đòi hỏi phải có hệ thống quản lí số liệu trong thời gian tới.

\section{Bảng 7. Chỉ tiêu và kết quả thực hiện của chương trình quản lí và phát triển rừng bền vững}

\begin{tabular}{|c|c|c|}
\hline STT & Chỉ tiêu, nhiệm vụ của chương trình & Kết quả thực hiện \\
\hline 1 & $\begin{array}{l}\text { Thiết lập lâm phận quốc gia ổn định } \\
\text { với } 3 \text { loại rừng. }\end{array}$ & $\begin{array}{l}\text { Từ năm } 2006 \text { đến 2020, cơ cấu diên tích } 3 \text { loại rừng đã tương đối ổn } \\
\text { định. Xin xem Hình 4, Hình } 5 \text { và Hình } 6 \text { dưới đây }\end{array}$ \\
\hline \multirow[t]{2}{*}{2} & \multirow{2}{*}{$\begin{array}{l}\text { Thực hiện quản lý rừng bền vững, các } \\
\text { chư rừng sản xuất kinh doanh xây } \\
\text { dựng và thực hiện phương án điều } \\
\text { chế rừng, ít nhất } 30 \% \text { diện tích RSX } \\
\text { được cấp chứng chỉ rừng }\end{array}$} & $\begin{array}{l}\text { - Theo báo cáo của TCLN, đến } 2019 \text { có } 266.974 \text { ha được cấp chứng } \\
\text { chỉ rừng bền vững tại } 24 \text { địa phương, trong đó năm } 2019 \text { đã cấp } \\
\text { chứng chỉ được } 43.691 \text { ha tại } 11 \text { tỉnh với } 15 \text { chủ rừng; so với tổng } \\
\text { diện tích RSX năm } 2019 \text { là hơn } 7,8 \text { triệu ha mới đạt } 3,4 \%\end{array}$ \\
\hline & & $\begin{array}{l}\text { - Mắc dù tổng diện tích rừng được cấp chứng chỉ quản lý rừng bền } \\
\text { vững đã đạt được } 46 \% \text { so với nhiệm vụ của chương trình bảo vệ } \\
\text { và phát triển rừng } 2016-2020 \text { theo Báo cáo Kết quả thực hiện và } \\
\text { kế hoạch triển khai năm } 2020 \text { của Chương trình mục tiêu phát } \\
\text { triển lâm nghiệp bền vững giai đoạn } 2016-2020 \text {, mục tiêu đến } \\
2020 \text { có } 30 \% \text { diện tích RSX được cấp chứng chỉ rừng như Chiến } \\
\text { lược để ra là không thể đạt }\end{array}$ \\
\hline 3 & $\begin{array}{l}\text { Trồng rừng mới } 1 \text { triệu ha đến năm } \\
2010 \text { và } 1,5 \text { triệu ha cho giai đoạn } \\
\text { tiếp theo,i }\end{array}$ & $\begin{array}{l}\text { Trồng rừng tập trung đạt trung bình } 227.500 \text { ha/năm, diện tích } \\
\text { rừng trồng năm } 2019 \text { hơn } 4,3 \text { triệu ha, vượt mục tiêu chiến lược 1,0 } \\
\text { triệu ha năm } 2010 \text { và 1,5 triệu ha cho giai đoạn sau. Tuy nhiên, diện } \\
\text { tích trồng mới (không bao gôm trồng lại sau khai thác) đến } 2019 \\
\text { mới đạt } 1,23 \text { triệu ha, bằng 82,2\% mức tiêu chiến lược và bằng } \\
98,65 \% \text { mục tiêu điểu chỉnh tại Quyết định số 57/QĐ-TTg } \\
\text { Xin xem thêm Bảng } 8 \text { và Hình } 8 \text { dưới đây }\end{array}$ \\
\hline 4 & Nâng cao năng suất RT & $\begin{array}{l}\text { Năng suất rừng trồng bình quân năm } 2019 \text { khoảng } 15 \mathrm{~m}^{3} / \mathrm{ha} / \mathrm{năm} \text {, } \\
\text { tăng } 1,5 \text { lần so với năm 2009, rừng trồng thâm canh các giống được } \\
\text { công nhận đạt } 20-25 \mathrm{~m}^{3} / \mathrm{ha} / \text { năm. Xin xem thêm tại Hình } 7 \text { dưới đây }\end{array}$ \\
\hline 5 & Làm giàu 0,5 triệu ha rừng nghèo kiệt & Không có số liệu về làm giàu rừng \\
\hline
\end{tabular}


Bảng 7. Tiếp trang trước

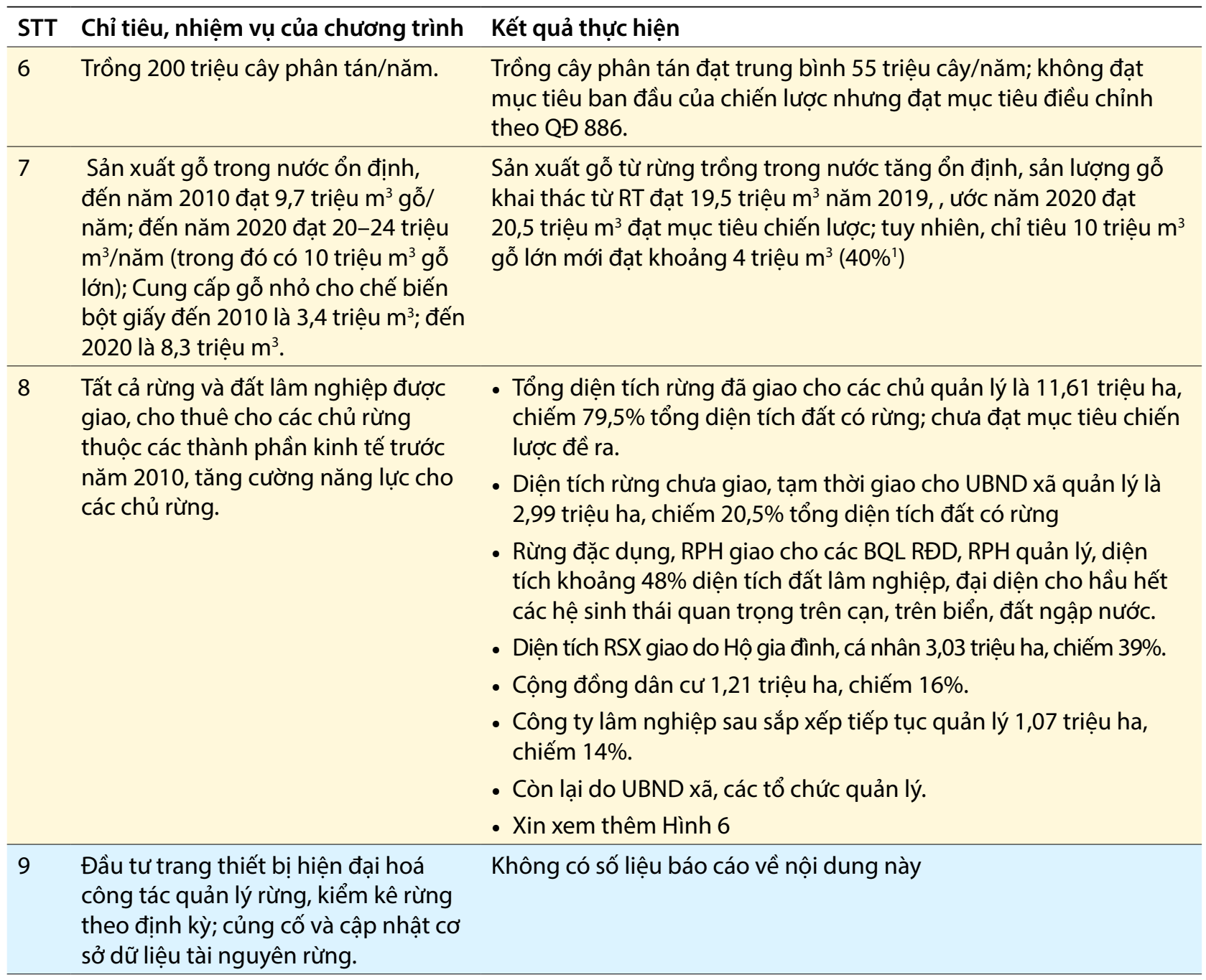

1 Theo kết quả khảo sát các địa phương, tỷ lệ gỗ lớn trong tổng lượng khai thác rừng trồng hiện nay chiếm khoảng 20\%.

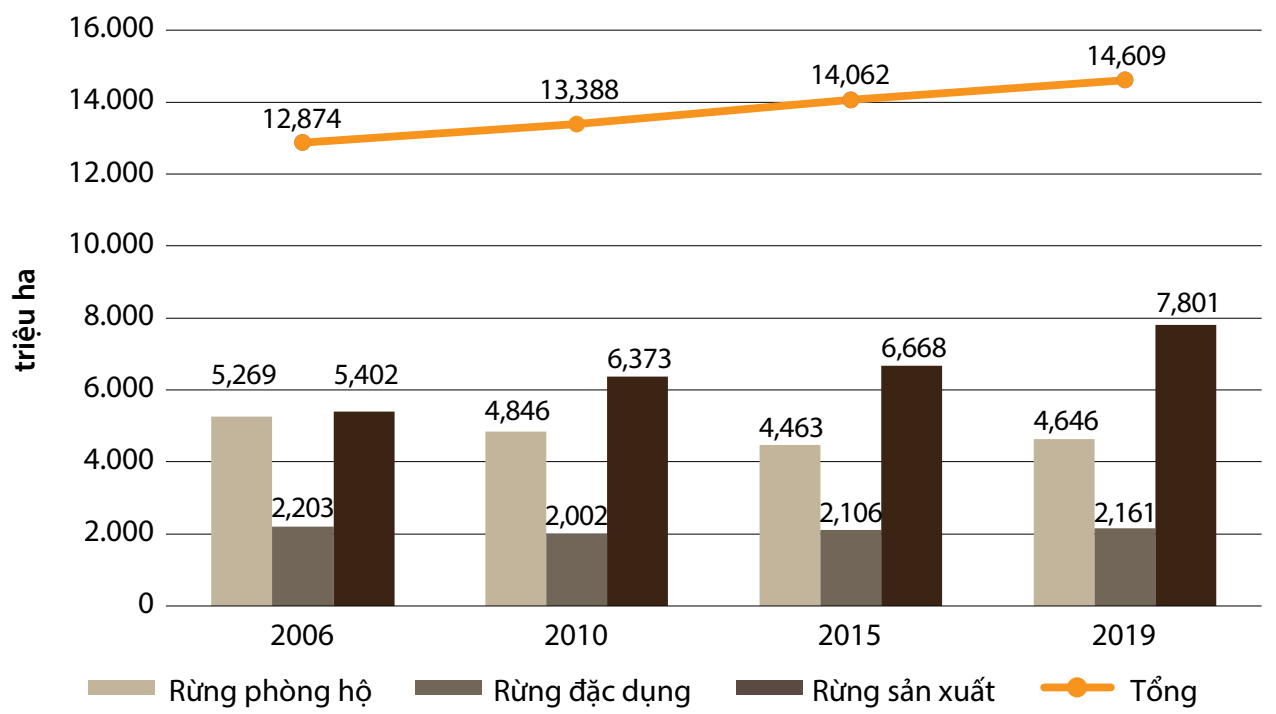

Hình 4. Diễn biến diện tích 3 loại rừng giai đoạn 2006-2019

Nguồn: Tác giả tổng hợp từ số liệu do Tổng cục Lâm nghiệp cung cấp, 2020. 


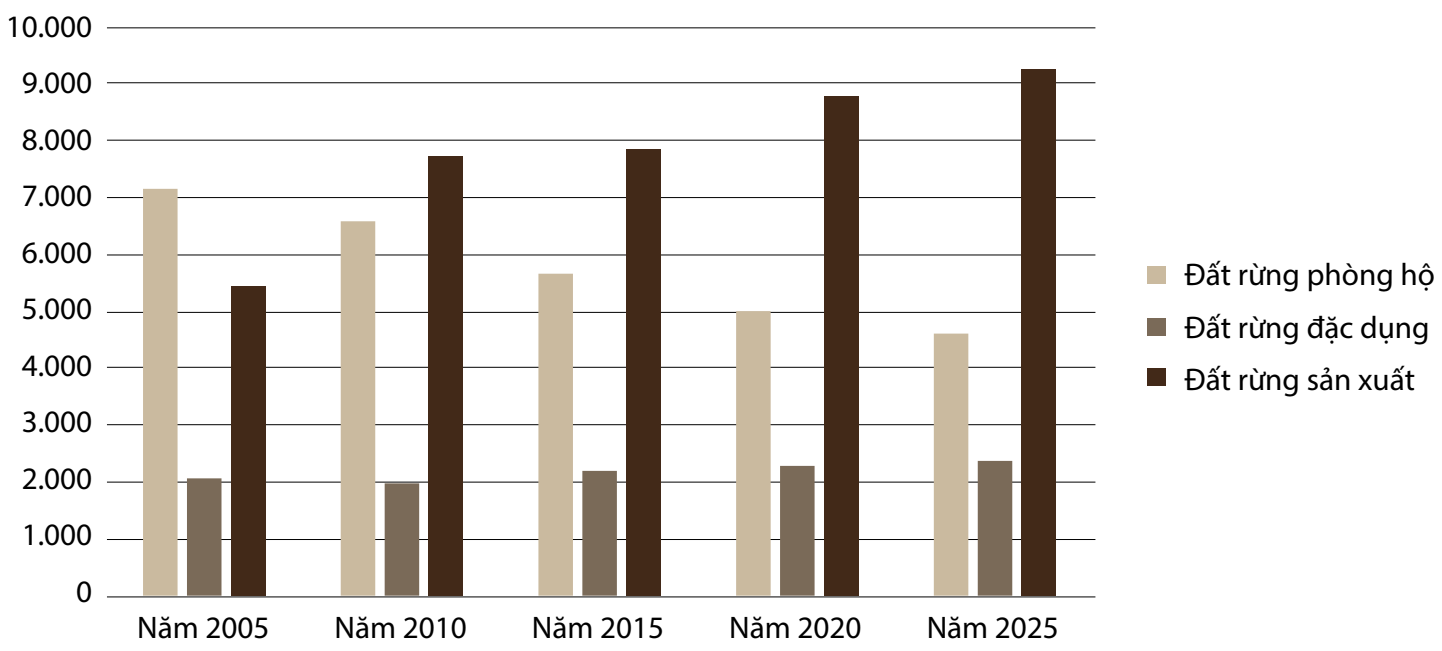

Hình 5. Diện tích đất lâm nghiệp giai đoạn 2006-2020

Nguồn: Vũ 2020.

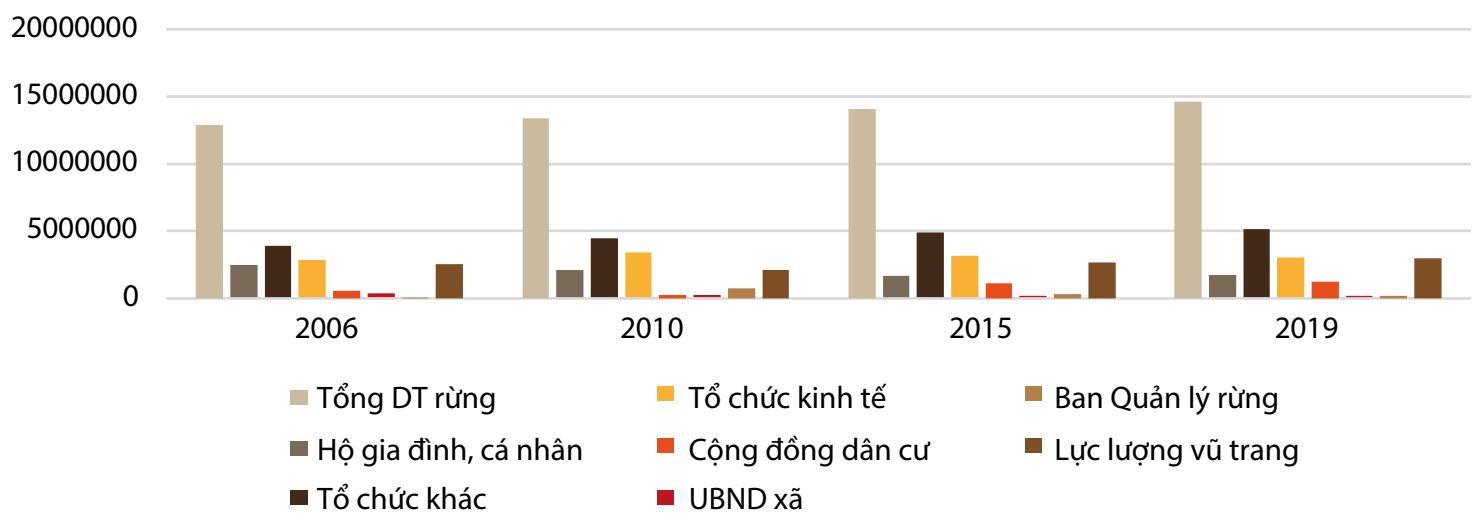

Hình 6. Diện tích rừng phân theo chủ quản lý giai đoạn 2006-2019 (ha)

Nguồn: Tác giả tổng hợp từ số liệu do Tổng cục Lâm nghiệp cung cấp, 2020

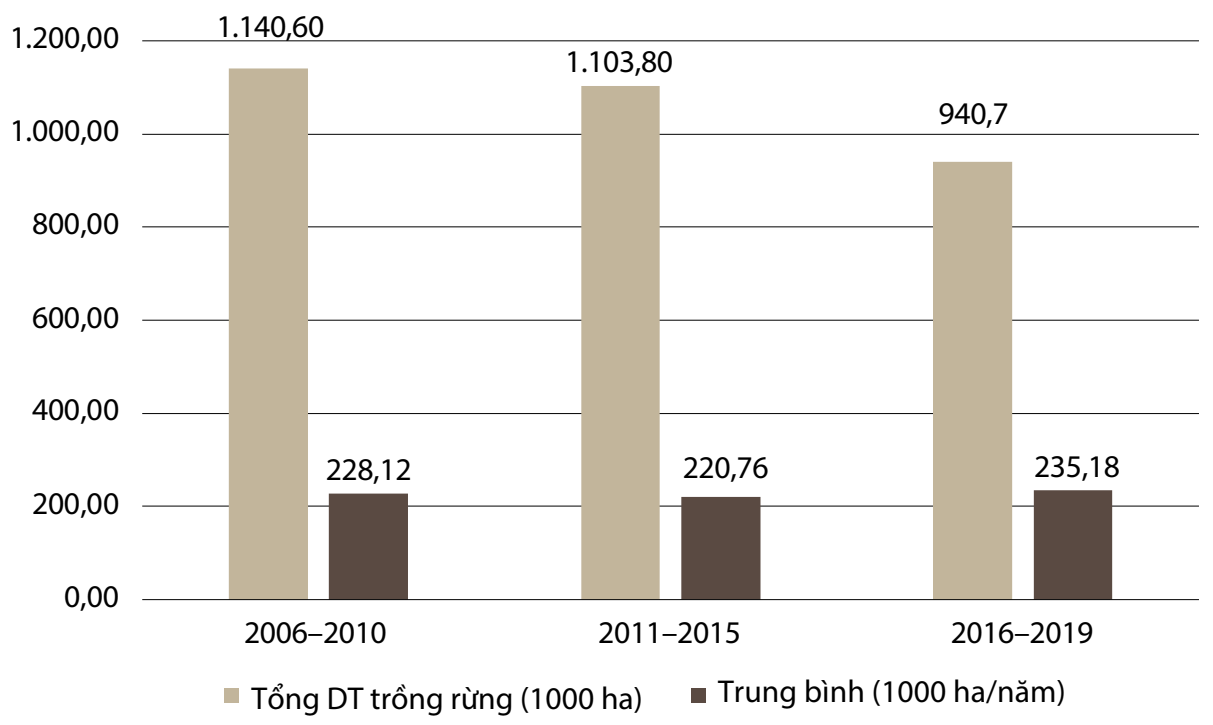

Hình 7. Trồng rừng tập trung giai đoạn 2006-2019

Nguồn: Tác giả tổng hợp từ số liệu do TCLN cung cấp, 2020 


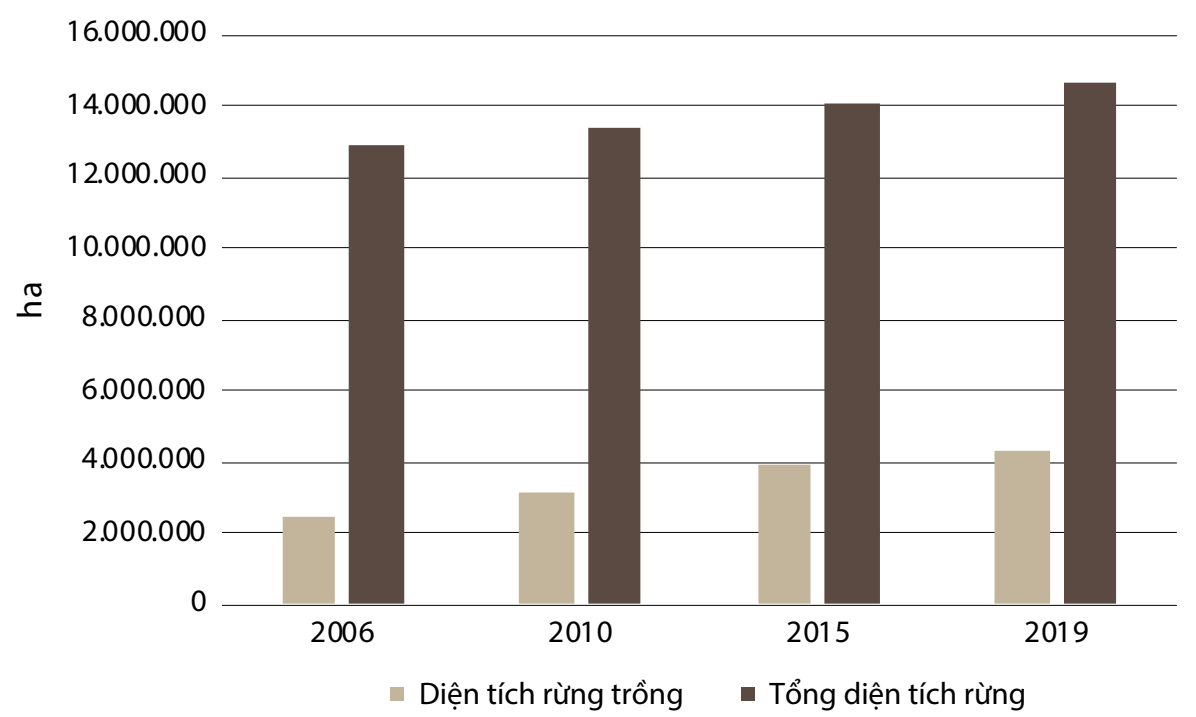

Hình 8. Diễn biến diện tích RT 2006-2019

Bảng 8. Tỷ lệ rừng trồng/tổng diện tích rừng giai đoạn 2006-2019

\begin{tabular}{lclll}
\hline Năm & 2006 & 2010 & 2015 & 2019 \\
\hline Tỷ lệ RT/TDTR (\%) & 19,14 & 23,03 & 27,64 & 29,55 \\
Tỷ lệ tăng so giai đoạn trước (\%) & - & 25,0 & 26,0 & 31,5 \\
\hline
\end{tabular}

Nguôn: Tác giả tổng hợp từ số liệu do TCLN cung cấp, 2020

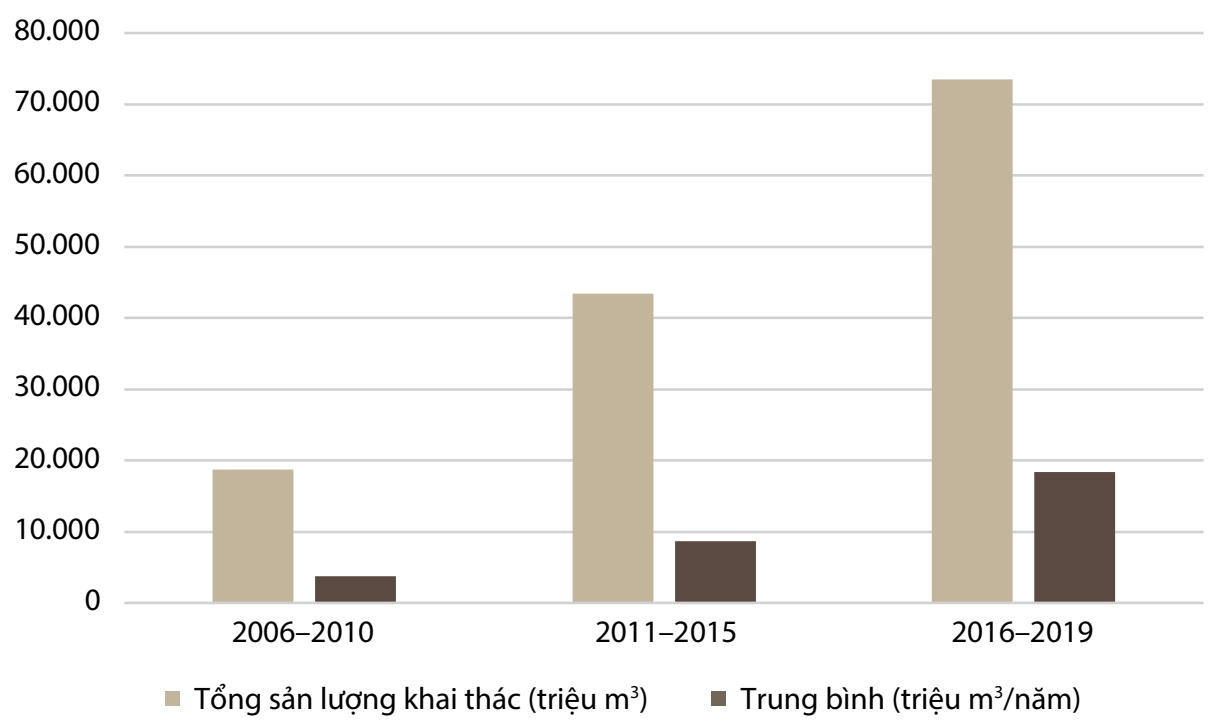

Hình 9. Sản lượng khai thác gỗ RT 2006-2019

Nguồn: Tác giả tổng hợp từ số liệu do TCLN cung cấp, 2020

\subsection{Chương trình bảo vê, bảo tồn đa dạng sinh học và phát triển các dịch vụ môi trường}

Bảng 9 cho thấy Chương trình bảo vệ, bảo tôn đa dạng sinh học và phát triển dịch vụ môi trường rừng đề ra 8 mục tiêu nhửng chỉ có $1 / 8$ mục tiêu này đã đạt được như Chiến lược đề ra. Rất nhiều chỉ số không có số liệu minh chứng rõ ràng, toàn diện và đây đủ về việc mục tiêu này có đạt được mục tiêu đề ra hay không. 
Bảng 9. Kết quả đạt được của Chương trình bảo vệ, bảo tồn đa dạng sinh học và phát triển dịch vụ môi trường rừng

\section{Khái quát chỉ tiêu nhiệm vụ Chương trình}

Bảo vệ có hiệu quả 16,24 triệu ha rừng và đất lâm nghiệp.

\section{Kết quả đạt được}

Đến 2019, tổng diện tích rừng được quản lý, bảo vệ là 14,6 triệu ha, bằng 89,9\% mục tiêu chiến lược, nhưng vượt mục tiêu chương trình 886 là 14,4 triệu ha.

$100 \%$ các văn bản quy định về bảo vệ rừng được tuyên truyền phổ biến đến các chủ rừng và người dân. Tuy nhiên có một số các báo cáo về việc người dân không tiếp cận được các thông tin liên quan đến chính sách lớn ví dụ như PFES (Yang và cộng sự 2015, Lê và cộng sự 2016)

Giảm $80 \%$ số vụ vi phạm pháp luật về bảo vệ và phát triển rừng.

Số vụ vi phạm giảm $57,6 \%$, chưa đạt mục tiêu chiến lược, nhưng đạt mục tiêu chương trình 886 (30-35\%) (Xin xem thêm bảng 10 dưới đây)

Tăng cường đầu tư cơ sở hạ tầng, trang thiết bị, chi phí hoạt động cho bảo vệ, phòng cháy, chữa cháy và phòng trừ sâu bênh hại rừng.

Đã có 58/63 tỉnh/thành phố thành lập Ban chỉ huy về những vấn đề cấp bách trong bảo vệ rừng, phòng cháy, chữa cháy rừng, với hơn 460/520 huyện có rừng và 4.816/5.985 xã có rừng thành lập các Ban chỉ huy để chỉ đạo, điều hành và kiểm tra đôn đốc các chủ rừng tổ chức thực hiện công tác bảo vệ rừng, phòng cháy, chữa cháy rừng trên địa bàn; đồng thời trực tiếp chỉ huy công tác chống chặt phá rừng và chữa cháy rừng ở cơ sở. Tuy nhiên, không có số liệu về kết quả thực hiện các nội dung này, nhất là về quản lý sâu bệnh hại.

Nghiên cứu định giá các DVMTR, xây dựng cơ chế chi trả cho các dịch vụ môi trường của ngành lâm nghiệp. Từ năm 2007 xây dựng và triển khai hoạt động Quỹ bảo vệ và phát triển rừng.

Thành lập được hệ thống Quỹ bảo vệ và phát triển rừng, bao gồm Quỹ trung ương trực thuộc Bộ $N N$ và PTNT và 45 Quỹ tỉnh, trong đó 11 Quỹ trực thuộc UBND tỉnh, 34 Quỹ trực thuộc sở NN và PTNT

Xây dựng và củng cố hệ thống RPH với tổng diện tích 5,68 triệu ha và hệ thống RĐD với tổng diện tích khoảng 2,16 triệu ha.

\section{- Rừng đặc dụng: Hiện nay, cả nước có 164 BQL RĐD,} quản lý 99,6\% diện tích rừng đặc dụng, trong đó: 33 BQL VQG; 57 BQL Khu Dự trữ thiên nhiên, 12 BQL Khu Bảo tồn loài-sinh cảnh và $53 \mathrm{BQL}$ Khu bảo vệ cảnh quan do các cơ quan địa phương quản lý; 9 BQL khu rừng nghiên cứu thực nghiệm khoa học

- Rừng phòng hộ: Hiện nay, cả nước có 231 BQL RPH. Hệ thống tổ chức quản lý RPH tại các địa phương chưa thống nhất: 153 Ban quản lý RPH trực thuộc Sở NN\&PTNT; 55 Ban trực thuộc UBND huyện; 5 Ban trực thuộc UBND tỉnh và 18 Ban trực thuộc Chi cục kiểm lâm.

- Không có số liệu về diện tích RPH và RĐD đã được quản lí hiệu quả

Tiếp tục thử nghiệm và nhân rộng mô hình quản lý Không có số liệu về kết quả thực hiện các nội dung này. bảo vệ rừng cộng đồng và các hình thức khác.

$100 \%$ các chủ rừng, thôn, xã có rừng có lực lượng bảo vệ rừng; $100 \%$ khu RPHvà RĐD có chủ quản lý, có quy hoạch, kế hoạch BV\&PTR; $100 \%$ cán bộ, nhân viên BV\&PTR được đào tạo nâng cao năng lực.
Đến nay đã có 512/1093 (46,84\%) tổ chức đã thành lập lược lượng bảo vệ chuyên trách 
Bảng 10. Số vụ vi phạm Luật bảo vệ và phát triển rừng và diện tích rừng bị hại

\begin{tabular}{lcccc}
\hline Chỉ số & ĐVT & $\begin{array}{c}\text { Giai đoạn 2006- } \\
\text { 2010 (Chính phủ } \\
\text { Việt Nam 2017) }\end{array}$ & $\begin{array}{c}\text { Giai đoạn 2011- } \\
\text { 2015 (Chính phủ } \\
\text { Việt Nam 2017) }\end{array}$ & $\begin{array}{c}\text { Giai đoạn 2016- } \\
\text { 2020 (Chính phủ } \\
\text { Việt Nam 2019) }\end{array}$ \\
\hline Tổng số vụ vi phạm & Vụ & 195.825 & 136.125 & 83.000 \\
Số vụ vi phạm trung bình & $\%$ & 100 & 69,5 & 42,4 \\
& Vụ/năm & 39.165 & 27.265 & 16.600 \\
Tổng diện tích bị thiệt hại & $\%$ & 100 & 69,6 & 9.100 \\
& ha & 27.732 & 13.239 & 32,8 \\
Diện tích bị thiệt hại trung bình & ha/năm & 100 & 47,7 & 1.820 \\
\end{tabular}

Nguồn: Tác giả tổng hợp từ số liệu do TCLN cung cấp

Tuy chương trình đề cập tới bảo tôn đa dạng sinh học, phỏng vấn với các chuyên gia cho thấy hiệu quả của công tác bảo tồn đa dạng sinh học rừng chưa cao là do các mục tiêu đa dạng sinh học không được đề cao trong quy hoạch, quản lý và đâu tư lâm nghiệp. Trong chiến lược phát triển lâm nghiệp (các giai đoạn trước) đề cập đến bảo tồn đa dạng sinh học, nhửng không có mục tiêu cụ thể (các ngưỡng cần đạt được) về khía cạnh này. Ngay tại các khu RĐD, nơi có mục tiêu cao nhất là bảo tôn thiên nhiên, việc đầu tư cho các hoạt động bảo tôn đa dạng sinh học đều chiếm tỷ trọng rất thấp (thậm chí không có) trong tổng đầu tư. Không có tiêu chuẩn hoặc yêu cầu báo cáo cụ thể nào về tình trạng và diễn biến đa dạng sinh học (ngoại trừ độ che phủ rừng). Điêuu này không khuyến khích các ban quản lý chú trọng đến công tác bảo tôn.
Trong chương trình này, mục tiêu đạt được duy nhất của Chiến lược là Dịch vụ môi trường rừng. Hình 10 cho thấy, nguồn thu từ dịch vụ môi trường rừng (PFES) qua các năm tăng mạnh.

PFES đã và đang nhận được sự quan tâm và hỗ trợ đáng kể từ Chính phủ, các bộ ngành có liên quan và đã có rất nhiều các văn bản pháp lý đã được ban hành dưới dạng Nghị định, Quyết định của Thủ tướng; Thông tư và Quyết định của Bộ Nông nghiệp và Phát triển Nông thôn, tạo nên một cơ sở pháp lý quan trọng cho việc triển khai Chính sách chi trả dịch vụ môi trường rừng. Tuy nhiên, theo Phạm và cộng sự (2013), thực hiện PFES còn gặp rất nhiều khó khăn do công tác kiểm kê rừng chưa hoàn thiện, sự chậm chạp trong việc giao đất, giao rừng, số lượng lớn người cung cấp dịch vụ sống rải rác tại các vùng sâu,

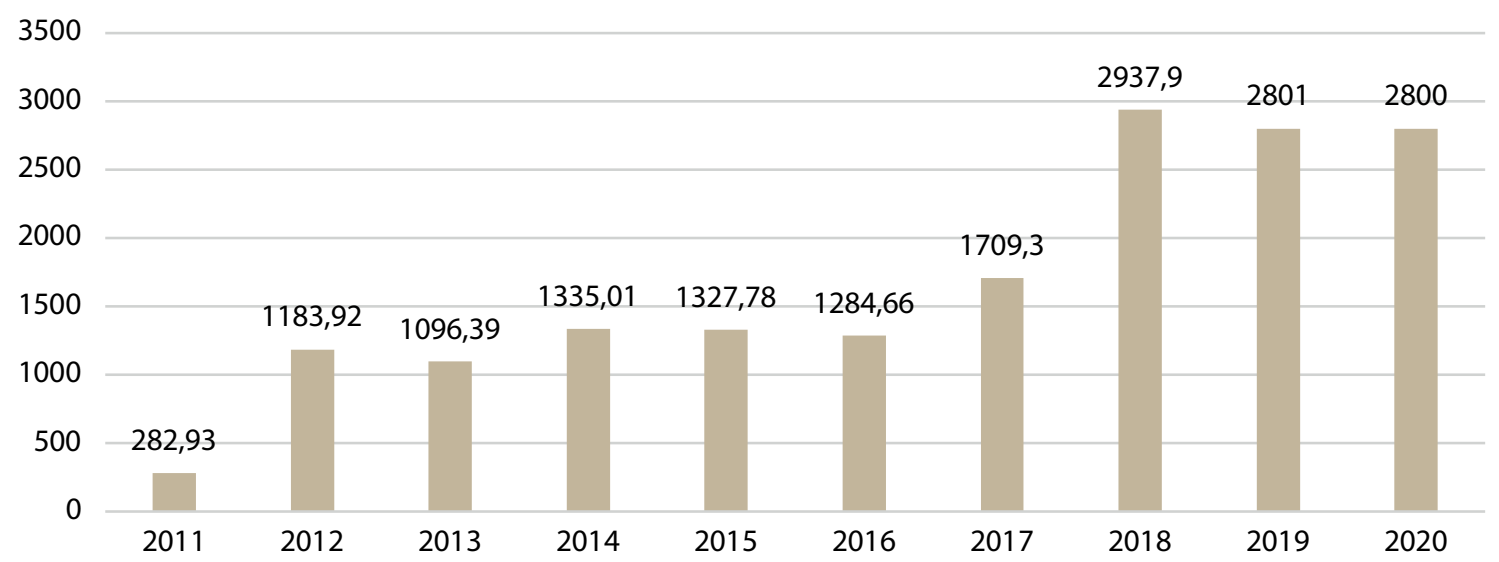

Hình 10. Tổng thu DVMTR giai đoạn 2011-2020

Nguồn: Tác giả tổng hợp từ số liệu do Tổng cục LN cung cấp, 2020, đơn vị tỷ đồng 
vùng xa, năng lực kỹ thuật và tài chính hạn chế ở cả cấp trung ương và địa phương, và sự phối hợp chưa chặt chẽ giữa các cơ quan, chi phí giao dịch cao do số lượng lớn các chủ rừng (các chủ rừng là cá nhân, hộ gia đình), thủ tục hành chính phức tạp, năng lực hạn chế của cán bộ thực hiện, các mâu thuẫn về lợi ích, việc chia sẻ thông tin và hợp tác chưa chặt chẽ giữa các cơ quan liên quan, sự chưa rõ ràng về tư cách pháp nhân của cộng đồng để tham gia vào những thỏa thuận về PFES làm giảm sự quan tâm của các cộng đông địa phương tới việc bảo vệ và phát triển rừng, và mức chi trả thấp đối lập chi phí cơ hội cao. Quan trọng hơn là hâuu hết các hướng dẫn chính sách cho PFES đều tập trung vào cơ cấu tổ chức và hoạt động của Quỹ Bảo vệ và Phát triển rừng ở các cấp và hướng dẫn báo cáo tài chính mà chưa có hướng dẫn cụ thể về công tác giám sát và đánh giá (Phạm và cộng sự 2013, Phạm và cộng sự 2018d). Một số thách thức trong việc nâng cao tính hiệu quả của PFES cũng được Phạm và cộng sự (2018d) tổng hợp (Hộp 3).

Kết quả phỏng vấn với các chuyên gia cho thấy tuy chỉ số liên quan tới số vụ vi phạm phần nào phản ánh được thực tế về tình trạng thực thi lâm luật tại cấp địa phương, do vậy gián tiếp thể hiện hiệu quả đầu ra về mặt môi trường, chỉ số này chưa hẳn đã thể hiện chất lượng rừng và giá trị môi trường của rừng. Số lượng vụ vi phạm có thể nhỏ nhưng nếu quy mô và tác động của số vụ vi phạm lại cao thì cũng không thể hiện được đầy đủ tác động về mặt môi trường. Chính vì vậy cần phải bổ sung các tiêu chí đánh giá khác đặc biệt các chỉ số thể hiện chất lượng rừng và các chỉ tiêu liên quan đến đa dạng sinh học. Chỉ tiêu về xây dựng đội chuyên trách bảo vệ rừng tại cấp thôn, bản và cấp xã cũng chưa đạt được bởi điều này phụ thuộc rất nhiểu vào nguôn tài chính, sự gắn kết của cộng đông và năng lực quản lí của chính quyền thôn bản.

\subsection{Chương trình chế biến gỗ và thương mại lâm sản}

Chế biến gỗ và thương mại lâm sản được kì vọng sẽ là ngành kinh tế mũi nhọn của Việt Nam đồng thời tạo ra công ăn việc làm cho 2 triệu người dân. Bảng 11 cho thấy các mục tiêu đề ra cho chương trình chế biến gỗ và thương mại lâm sản đều đạt được hoặc hoàn thành vượt quá chỉ tiêu, chỉ riêng của sản xuất lâm sản ngoài gỗ là không đạt được như kì vọng.

\section{Hộp 3. Thách thức trong việc nâng cao tính hiệu quả của PFES}

- Việc mất rừng và suy thoái rừng diễn ra nhiều nhất ở vùng Bắc Trung Bộ, Đông Bắc, Tây Nguyên và Tây Bắc Việt Nam (Chính phủ Việt Nam 2016). Tuy nhiên cho đến nay, nguồn thu từ chi trả DVMTR chủ yếu tập trung và phân bổ ở Tây Bắc và Tây Nguyên (tương ứng là $37 \%$ và $35 \%$ ) do hai vùng này có tổng diện tích đất lâm nghiệp chiếm tỷ lệ cao nhất ( $80 \%$ và $60 \%)$, trong khi nguồn thu (và phân phối) ở Bắc Trung Bộ và Đông Bắc còn hạn chế (tương ứng là $6 \%$ và $11 \%$ ).

- Các khu vực rừng ngập mặn lớn nhất ở Việt Nam tập trung ở khu vực Nam Trung Bộ và Đông Nam Bộ - đóng một vai trò quan trọng trong thích ứng và giảm thiểu biến đổi khí hậu và trong đóng góp tự nguyện quốc gia (NDC). Tuy vậy, nguồn thu PFES phân bổ cho các vùng này chỉ từ $2 \%$ đến $9 \%$

- Mặc dù có kỳ vọng cao về nguồn thu và tác động của chi trả DVMTR, trong tổng số 40 Quỹ Bảo vệ và Phát triển rừng của tỉnh, chỉ có 13\% quỹ tỉnh có nguồn thu từ chi trả DVMTR lớn hơn 100 tỷ đồng, 17,5\% quỹ tỉnh có nguồn thu dưới 1 tỷ đồng (Biểu đồ 5). Theo số liệu từ phỏng vấn các bên liên quan, các tỉnh có thu nhập từ DVMTR dưới 1 tỷ đồng rất khó có thể trang trải chi phí hoạt động căn bản và một số tỉnh còn phải hỗ trợ bổ sung kinh phí để thực hiện chi trả DVMTR. Tại các tỉnh này, chính quyền địa phương đang phải cân nhắc phương pháp để tối ưu tính hiệu quả của việc sử dụng nguồn thu DVMTR.

- Tương tự như vậy, mặc dù Việt Nam có 33 vườn quốc gia và 174 khu bảo tồn, theo số liệu của VNFF (2018) cho thấy, chỉ có 13 vườn quốc gia $(39,3 \%)$ và 36 khu bảo tồn $(20,68 \%)$ có được nguồn thu từ chi trả DVMTR. Biểu đồ 5 cũng chỉ ra rằng chỉ có $6 \%$ khu bảo tồn có nguồn thu từ chi trả DVMTR hơn 10 tỷ đồng so với $31 \%$ vườn quốc gia, $28 \%$ khu bảo tồn và $15 \%$ vườn quốc gia nhận được dưới 500 triệu đồng/năm. Điều này cho thấy, cũng chỉ một số ít các vườn quốc gia và các khu bảo tồn đang tiếp cận được với chi trả DVMTR, vì vậy, nguồn thu từ chi trả DVMTR không đáng kể đối với nhiều vườn quốc gia 
Bảng 11. Mục tiêu và kết quả thực hiện của chương trình chế biến gỗ và thương mại lâm sản

\begin{tabular}{|c|c|c|c|c|}
\hline \multirow{2}{*}{\multicolumn{2}{|c|}{ Mục đích chương trình }} & \multicolumn{3}{|c|}{ Kết quả } \\
\hline & & 2006 & 2019 & 2020 \\
\hline \multicolumn{2}{|c|}{ Tổ chức lại ngành công nghiệp chế biến gỗ } & $\begin{array}{l}1.200 \mathrm{DN}^{-} \\
\mathrm{CBG}^{1}\end{array}$ & & $\begin{array}{l}5.500 \mathrm{DN} \\
\mathrm{CBG}^{2}\end{array}$ \\
\hline \multirow{4}{*}{$\begin{array}{l}\text { Tăng cường năng } \\
\text { lực sản xuất công } \\
\text { nghiệp chế biến } \\
\text { lâm sản để đáp ứng } \\
\text { cơ bản các nhu cầu } \\
\text { trong nước và xuất } \\
\text { khẩu }\end{array}$} & $\begin{array}{l}\text { Giá trị sản xuất gỗ xuất khẩu tăng } 7 \text { tỷ } \\
\text { USD ( } 3,5 \text { triệu m³ sản phẩm) (xin xem } \\
\text { thêm Hình } 11 \text { dưới đây) }\end{array}$ & 2,18 tỷ USD & 11,3 tỷ USD & $\begin{array}{l}12,7 \text { tỷ USD } \\
\text { (ước tính) }\end{array}$ \\
\hline & $\begin{array}{l}\text { Tổng giá trị thương mại xuất khẩu và tiêu } \\
\text { thụ nội địa tăng }\end{array}$ & & 15 tỷ USD & \\
\hline & Thị trường xuất khẩu được mở rộng & $\begin{array}{l}60 \text { quốc } \\
\text { gia và vùng } \\
\text { lãnh thổ }\end{array}$ & $\begin{array}{l}140 \text { quốc } \\
\text { gia và vùng } \\
\text { lãnh thổ }\end{array}$ & \\
\hline & $\begin{array}{l}\text { Chủ động nguyên liệu gỗ phục vụ cho } \\
\text { chế biến, sản xuất, tiêu thụ trong nước và } \\
\text { xuất khẩu }\end{array}$ & & $\begin{array}{l}\text { 75\% nguyên } \\
\text { liệu }\end{array}$ & \\
\hline \multicolumn{2}{|c|}{$\begin{array}{l}\text { Lâm sản ngoài gỗ trở thành ngành sản xuất chính } \\
\text { Giá trị xuất khẩu LSNG năm } 2020 \text { đạt 0,8 tỷ USD }\end{array}$} & 0,23 tỷ USD & & $\begin{array}{l}0,9 \text { tỷ USD } \\
\text { (ước tính) }\end{array}$ \\
\hline $\begin{array}{ll}1 & 31 \% \text { DN nhà nước, } 65 \\
2 & 5 \% \text { DN nhà nước, } 95 \% \\
3 & \text { Tập trung } 5 \text { thị trường } \\
4 & \text { Chiếm trên 20\% tổng }\end{array}$ & $\begin{array}{l}\text { \% DN tư nhân, 4\% DN liên doanh } \\
\text { DN tư nhân } \\
\text { chính : Hoa Kỳ(43\%), Trung Quốc (14,6\%), Nhật Bản }\end{array}$ & 14,1\%), EU (gần 1 & 6), Hàn Quốc (8,2 & \\
\hline
\end{tabular}

Tuy nhiên, ngành Chế biến và thương mại lâm sản (CB\&TMLS) còn một số hạn chế, tôn tại (Hoàng 2020):

- Quy mô doanh nghiệp hâu hết là nhỏ và siêu nhỏ, chỉ có $3,5 \%$ có vốn đâu tư trên 50 tỷ đông

- Chưa có nhiều sản phẩm chế biến sâu, có giá trị cao, mang thương hiệu Việt Nam

- Tỷ trọng xuất gỗ dăm, sản phẩm thô và nguyên liệu LSNG còn lớn

- Chưa có sự liên kết giữa cung cấp nguyên liệu và chế biến

- Chưa tạo được vùng nguyên liệu tập trung
- Chưa chủ động được nguyên liệu gôc lớn, chất lượng cao

- Không kiểm soát được chất lượng "đầu vào" của sản phẩm chế biến

- Xúc tiến thương mại, phát triển thị trường hạn chế

Ngoài ra, việc mở rộng phát triển ngành công nghiệp gỗ ở Việt Nam đang đối mặt với rất nhiêu khó khăn trong việc cạnh tranh về nguyên liệu thô và áp lực tuân thủ các hiệp định quốc tế mới như FLEGT/VPA (Phạm và cộng sự 2020).

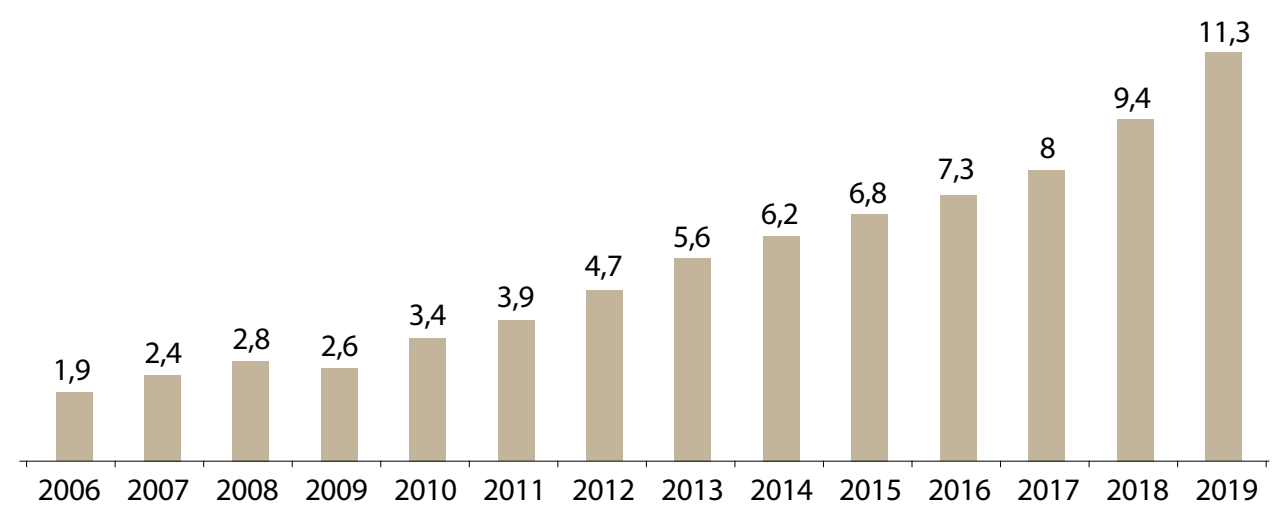

Hình 11 . Giá trị xuất khẩu lâm sản 2006-2020 


\subsection{Chương trình nghiên cứu, giáo dục, đào tạo và khuyến lâm}

Bảng 12 cho thấy Chương trình nghiên cứu, giáo dục, đào tạo và khuyến lâm có 9 mục tiêu và chỉ tiêu. Tuy nhiên chỉ có $2 / 9$ mục tiêu này đã đạt được và vượt kế hoạch đề ra. Một số nguyên nhân cho việc này được lí giải ở trên phân mục tiêu xã hội nói trên cũng như trong Bảng 12 dưới đây.

\section{Bảng 12. Mục tiêu và kết quả thực hiện của chương trình nghiên cứu, giáo dục, đào tạo và khuyến lâm}

\begin{tabular}{|c|c|c|}
\hline STT & $\begin{array}{l}\text { Chỉ tiêu, nhệm vụ của } \\
\text { chương trình }\end{array}$ & Kết quả thực hiện \\
\hline \multirow[t]{4}{*}{1} & \multirow[t]{4}{*}{$\begin{array}{l}\text { Hoàn thiện và cập } \\
\text { nhật chương trình, } \\
\text { giáo trình đào tạo; } \\
\text { liên kết đào tạo với } \\
\text { khuyến lâm. }\end{array}$} & $\begin{array}{l}\text { - Hợp tác giữa Trường Đại học Lâm nghiệp và Trường Đại học Colorado, Hoa } \\
\text { Kỳ từ năm } 2010 \text { đã xây dựng Chương trình ngành Quản lý tài nguyên thiên } \\
\text { nhiên và đào tạo được hơn } 200 \text { kỹ sư; Chương trình thạc sỹ quốc tế ngành } \\
\text { Lâm nghiệp hợp tác với Đức, Lào, Campuchia từ } 2017 \text { đến } 2019 \text { đã tuyển được } \\
29 \text { học viên từ } 6 \text { nước; }\end{array}$ \\
\hline & & $\begin{array}{l}\text { - Một số dự án hợp tác quốc tế về xây dựng khung chương trình đào tạo đã được } \\
\text { thực hiện như: chương trình về Biến đổi khí hậu vùng do USAID tài trợ; Chương } \\
\text { trình về Giảm phát thải từ mất rừng và suy thoái rừng (REDD+) do UNEP tài trợ; } \\
\text { chương trình về QLRBV và kinh tế sinh học được tài Chương trình Erasmus+ }\end{array}$ \\
\hline & & - Cán bộ khuyến lâm cơ sở chưa đáp ứng yêu cầu về số lượng và chất lượng \\
\hline & & $\begin{array}{l}\text { - Mối liên kết giữa nghiên cứu, đào tạo và khuyến lâm chưa thật sự hiệu quả, khả } \\
\text { năng ứng dụng của các kết quả nghiên cứu và chuyển giao công nghệ, kỹ thuật } \\
\text { vào thực tiễn còn hạn chế và thiếu tính bền vững (Trần 2020) }\end{array}$ \\
\hline \multirow[t]{2}{*}{2} & \multirow[t]{2}{*}{$\begin{array}{l}\text { Đào tạo chính quy } \\
5.000 \text { sinh viên/năm, } \\
\text { đào tạo nghề cho nông } \\
\text { dân làm nghề rừng và } \\
\text { các làng nghề CBLS. }\end{array}$} & $\begin{array}{l}\text { - Đào tạo chính quy ngành lâm nghiệp có sự phát triển không ổn định. Trường } \\
\text { Đại học Lâm nghiệp giai đoạn trước } 2015 \text { có lượng sinh viên khá lớn, riêng năm } \\
2014 \text { có tới } 4.800 \text { sinh viên; từ năm } 2016 \text { đến nay có khó khăn về thu hút người } \\
\text { học vào ngành Lâm nghiệp và số sinh viên giảm rõ rệt, từ } 2018 \text { đến } 2020 \text { trung } \\
\text { bình mỗi năm Trường Đại học Lâm nghiệp và các phân hiệu trực thuộc tuyển } \\
\text { được } 1.000-1.500 \text { sinh viên các bậc đào tạo, trong đó bậc đại học chính quy chỉ } \\
500-600 \text { sinh viên'. }\end{array}$ \\
\hline & & $\begin{array}{l}\text { - Sự mâu thuẫn giữa sự phát triển của xuất khẩu gỗ với số sinh viên theo học } \\
\text { ngành Chế biến lâm sản phần nào phản ánh sự bất cập giữa nội dung, chương } \\
\text { trình và hình thức đào tạo với nhu cầu thực tế của xã hội. }\end{array}$ \\
\hline \multirow[t]{2}{*}{3} & \multirow[t]{2}{*}{$\begin{array}{l}\text { Đến năm } 2020 \text { có từ } \\
1-2 \text { trường lâm nghiệp } \\
\text { đạt chuẩn quốc tế. }\end{array}$} & $\begin{array}{l}\text { - Hợp tác quốc tế trong đào tạo và nghiên cứu lâm nghiệp đã đạt được những } \\
\text { bước tiến mới, đã xây dựng và vận hành thành công các chương trình đào tạo } \\
\text { liên kết với các trường ĐH nước ngoài và thực hiện các dự án hợp tác nghiên } \\
\text { cứu với các tổ chức quốc tế góp phần đáp ứng yêu cầu đổi mới và hội nhập } \\
\text { quốc tế; }\end{array}$ \\
\hline & & $\begin{array}{l}\text { - Tuy nhiên, chưa có 1-2 trường đạt trình độ quốc tế chủ yếu do thiếu nguồn lực } \\
\text { đâuu tư; trong } 16 \text { lĩnh vực ưu tiên đầu tư của các bên có liên quan về lâm nghiệp } \\
\text { giai đoạn 2011-2019 không có nội dung đào tạo nguôn nhân lực (Phạm và } \\
\text { cộng sự 2020a) và tỷ lệ đấu tư cho chương trình nghiên cứu, giáo dục, đào tạo } \\
\text { và khuyến lâm chỉ chiếm 1,35\% tổng dự kiến đầu tư thực hiện chiến lược (Phạm } \\
\text { và cộng sự } 2018 \text { c) }\end{array}$ \\
\hline \multirow[t]{3}{*}{4} & \multirow{3}{*}{$\begin{array}{l}\text { Bố trí } 1 \text { cán bộ khuyến } \\
\text { lâm cho mỗi xã nhiều } \\
\text { rừng; phát triển } \\
\text { khuyến lâm tự nguyện; } \\
\text { liên kết khuyến lâm và } \\
\text { đào tạo với chư rừng } \\
\text { và doanh nghiệp. }\end{array}$} & $\begin{array}{l}\text { - Hình thành được hệ thống khuyến nông-lâm từ trung ương đến cơ sở với nhiều } \\
\text { hoạt động nâng cao năng lực cho người dân và chủ rừng và bước đầu hình } \\
\text { thành được mối liên kết giữa hệ thống nghiên cứu - đào tạo - khuyến lâm. }\end{array}$ \\
\hline & & $\begin{array}{l}\text { - Cán bộ khuyến lâm cơ sở chưa đáp ứng yêu cầu về số lượng và chất lượng } \\
\text { (Moeliono và cộng sự 2016) }\end{array}$ \\
\hline & & • Chỉ tiêu 100\% xã có nhiều rừng có cán bộ khuyến lâm không đạt được \\
\hline
\end{tabular}


Bảng 12. Tiếp trang trước

\begin{tabular}{cl}
\hline STT & $\begin{array}{l}\text { Chỉ tiêu, nhệm vụ của } \\
\text { chương trình }\end{array}$ \\
\hline 5 & $\begin{array}{l}\text { Tập trung nghiên cứu } \\
\text { một số lĩnh vực mũi }\end{array}$ \\
& nhọn, cải tiến công \\
& nghệ cho công nghiệp \\
& CBLS, xây dựng chính \\
& sách có tính đột phá \\
& trong ngành lâm \\
& nghiệp.
\end{tabular}

\section{Kết quả thực hiện}

- Công tác nghiên cứu đã tập trung vào các lĩnh vực mũi nhọn của ngành² và đã đóng góp tích cực vào các thành tựu của ngành về tỷ lệ che phủ rừng, giá trị xuất khẩu gỗ, các nguồn tài chính đa dạng cho phát triển lâm nghiệp;

- Bộ NN- PTNT đã xây dựng và thực hiện Chiến lược nghiên cứu lâm nghiệp Việt Nam đến năm 2020 theo Quyết định số 78/2008/QĐ-BNN ngày 01/7/2008. Mục tiêu tổng quát của Chiến lược nghiên cứu lâm nghiệp là "góp phần định hường phát triển lâm nghiệp, thực hiện có hiệu quả Chiến lược PTLN và Kế hoạch tổng thể nghiên cứu Nông nghiệp Việt Nam tới năm 2020, phục vụ yêu cầu công nghiệp hóa, hiện đại hóa nông nghiệp, nông thôn Việt Nam tới năm 2020" với 3 mục tiêu cụ thể: i) cung cấp cơ sở khoa học cho định hướng phát triển ngành theo hướng xã hội hóa, ii) Sản xuất lâm nghiệp và bảo tồn đa dạng sinh học, iii) tăng cường năng lực nghiên cứu. Chiến lược gồm 3 nội dung chính: i) Xác định ưu tiên nghiên cứu; ii) Tăng cường năng lực nghiên cứu và iii) Nâng cao hiệu quả nghiên cứu. Chiến lược đã xác định 6 lĩnh vực ưu tiên nghiên cứu: i) Quy hoạch, giám sát đánh giá tài nguyên rừng; ii) Chính sách và thể chế lâm nghiệp; iii) Quản lý rừng bền vững; iv) Môi trường rừng và đa dạng sinh học; v) Lâm học và kỹ thuật lâm sinh (RTN, RT, LSNG); vi) Công nghiệp rừng, Bảo quản và $C B L S$. Các giải pháp thực hiện bao gồm: i) Giải pháp về tổ chức nghiên cứu; ii) Giải pháp về phát triển nguồn nhân lực cho nghiên cứu; iii) Giải pháp về nguồn vốn; iv) Giải pháp về chính sách hỗ trợ nghiên cứu.

- Kết quả thực hiện Chiến lược nghiên cứu lâm nghiệp Việt Nam giai đoạn 20082020 đạt được những kết quả đáng khích lệ với 227 giống cây lâm nghiệp được công nhận là giống tiến bộ kỹ thuật và giống quốc gia, năng suất RT các loài cây chủ lực (keo, bạch đàn) đạt bình quân $20 \mathrm{~m}^{3} / \mathrm{ha} / \mathrm{năm}$; năng suất RTN đạt 4,3-6 m³/ha/năm; xây dựng được 45 TCVN về giống cây lâm nghiệp, 61 Tiêu chuẩn về kỹ thuật lâm sinh, 52 Tiêu chuẩn về bảo quản lâm sản; các kết quả nghiên cứu làm cơ sở cho việc xây dựng nhiều chính sách quan trọng của ngành (Tổng cục Lâm nghiệp 2020a)

- Số đề tài nghiên cứu về kinh tế, chính sách còn hạn chế, chưa đóng góp nhiều vào xây dựng các chính sách thu hút đầu tư vào lâm nghiệp; chưa làm rõ vai trò của ngành lâm nghiệp trong sự phát triển kinh tế xã hội bền vững của đất nước; chưa phát huy được vai trò của KH\&CN như một nhân tố quan trọng thúc đẩy tăng trưởng và tái cơ cấu, nâng cao giá trị gia tăng trong sản xuất lâm nghiệp.

6 Từ 2008, đưa giáo dục bảo vệ rừng và bảo vệ môi trường vào giảng dạy trong các trường học phổ thông.

$780 \%$ cán bộ quản lý rừng ở địa phương được đào tạo. Nâng cao năng lực các viện, trường lâm nghiệp.

Không có số liệu về kết quả thực hiện nội dung này

Đào tạo nâng cao và đào tạo lại cho cán bộ lâm nghiệp được thực hiện dưới nhiều hình thức đa dạng, góp phần nâng cao hiệu quả quản lý rừng và ngành lâm nghiệp. Trong ngành Chế biến và Thương mại lâm sản với khoảng 0,5 triệu lao động có 55-60\% được đào tạo đáp ứng yêu cầu nhiệm vụ (Tổng cục Lâm nghiệp 2020b). Các lĩnh vực khác không có số liệu báo cáo cụ thể về nội dung này.

Các mô hình khuyến lâm đã thu hút trên 58.350 hộ tham gia và trồng được khoảng 86.000 ha rừng trên 40 tỉnh, chủ yếu ở Miền núi phía bắc, Miền Trung và Tây nguyên. Hơn $80 \%$ số hộ nông dân vùng nguyên liệu giấy đã biết áp dụng kỹ thuật trồng rừng thâm canh đạt năng suất $15-20 \mathrm{~m}^{3} /$ năm đối với Bạch đàn, Keo lai. Nhiều mô hình nông lâm kết hợp cho thu hoạch bình quân 8-10 triệu đồng/ ha/năm, mô hình vườn rừng, trại rừng từ 10-15 triệu đồng/ha/năm (Trần 2020)

9 Nâng cao trình độ cho Không có số liệu về kết quả thực hiện nội dung này 80\% hộ nông dân 
Ngoài ra, một số thách thức khác trong việc thực hiện chương trình này bao gồm:

- Đầu tư từ nguôn vốn nhà nước vào chương trình nghiên cứu và đào tạo rất nhỏ, chỉ chiếm có $1,3 \%$ của tổng nhu câu vốn của cả 05 chương trình thuộc Chiến lược phát triển Lâm nghiệp giai đoạn 2006-2020 (Trần 2020).

- Số lượng và công trình nghiên cứu hiện nay chủ yếu tập trung vào kĩ thuật lâm sinh (chiếm khoảng 75\% tổng nguồn ngân sách nhà nước cho nghiên cứu), công nghiệp rừng, bảo quản và chế biến lâm sản $(16,4 \%)$ trong khi nghiên cứu về các lĩnh vực kinh tế, thị trường, đánh giá tác động của chính sách lại rất hạn chế. Ngân sách đâu tư cho các nghiên cứu về kinh tế, thị trường và thể chế lâm nghiệp chỉ chiếm có $2 \%$ và nghiên cứu về dịch vụ môi trường rừng, đa dạng sinh học chỉ chiếm có $6 \%$ tổng kinh phí dành cho nghiên cứu khoa học (Trần 2020). Chính điều này giảm khả năng ứng dụng thực tiễn của nhiều nghiên cứu khi quá chú trọng vào nhiệm vụ kĩ thuật. Sự thiếu hụt nghiên cứu trong các lĩnh vực mới và cân tính ứng dụng cao như định giá tài nguyên rừng, phát triển dịch vụ hệ sinh thái rừng, cho thuê môi trường rừng, phát triển thị trường, phát triển du lịch sinh thái, cơ chế tài chính và chính sách phát triển rừng, phát triển sản xuất theo chuỗi giá trị, thu hút đâu tư tư nhân vào ngành lâm nghiệp, chia sẻ lợi ích và hưởng lợi trong lâm nghiệp đã dẫn đến đánh giá và nhìn nhận không đây đủ của xã hội về vai trò của ngành lâm nghiệp (Trần 2020). Phần lớn các nghiên cứu hiện nay về lĩnh vực lâm nghiệp chủ yếu thực hiện và tài trợ bởi nguôn tài chính quốc tế thông qua các tổ chức nghiên cứu quốc tế như CIFOR, ICRAF và qua các tổ chức dân sự xã hội như PanNature.

- Trong giai đoạn 2008-2017, các nghiên cứu và các nhiệm vụ $\mathrm{KHCH}$ về lĩnh vực Lâm học và lâm sinh chủ yếu tập trung cho lĩnh vực rừng trông, sau đó đến lâm sản ngoài gỗ, rừng tự nhiên còn rất ít được quan tâm (Trần 2020). Phân lớn các nghiên cứu tập trung vào rừng tự nhiên đều được tài trợ bởi các tổ chức quốc tế khác.

\subsection{Chương trình đổi mới thể chế, chính sách, lập kế hoạch và giám sát ngành}

Phần lớn các bên tham gia phỏng vấn đều cho rằng hệ thống chính sách lâm nghiệp đã có nhiều tiến bộ nhửng vẫn chưa hoàn thiện, số lượng văn bản nhiêu nhửng còn chồng chéo, chưa thống nhất và hiệu quả thực thi thấp. Một số chính sách bất cập, chưa phù hợp thực tiễn nhưng chậm được điều chỉnh; thiếu các chính sách cụ thể để bảo đảm thực hiện được các tiêu chuẩn quản lý rừng bền vững theo thông lệ quốc tế. Một số lĩnh vực còn thiếu chính sách phù hợp như: chế biến lâm sản, thị trường, thương mại lâm sản, nghiên cứu, chuyển giao tiến bộ khoa học kỹ thuật trong lâm nghiệp, đào tạo nâng cao năng lực cho chủ rừng, khuyến lâm. 


\section{Bảng 13. Mục tiêu về thể chế và kết quả đạt được}

\begin{tabular}{l} 
Khái quát chỉ tiêu, nhiệm \\
vụ của chương trình \\
\hline Xây dựng và cập nhật hệ \\
thống chính sách pháp \\
luật và thể chế chính \\
sách, pháp luật theo \\
hướng phân cấp nhiều \\
hơn cho địa phương và \\
phát triển lâm nghiệp \\
bên vững theo hướng sản \\
xuất hàng hoá và xã hội \\
hoá nghể rừng
\end{tabular}

\section{Kết quả đạt được}

\section{Giai đoạn 2006-2010:}

- Nghị định số 99/2010/NĐ-CP ngày 24/9/2010 của Chính phủ về chính sách chi trả DVMTR;

- Quyết định số 147/2007/QĐ-TTg và Quyết định số 66/2011/QĐ-TTg của Chính phủ về chính sách phát triển RSX giai đoạn 2007-2015.

- Bộ NN\&PTNT đã phối hợp với các Bộ, ngành xây dựng, ban hành 100 văn bản quy phạm pháp luật về lĩnh vực lâm nghiệp, tạo khung pháp lý để tổ chức thực hiện phát triển lâm nghiệp.

\section{Giai đoạn 2011-2015:}

- Số văn bản quy phạm pháp luật về lâm nghiệp được xây dựng, ban hành là 48 văn bản.

- Hệ thống văn bản giai đoạn này đã thể chế hoá kịp thời chủ trương, chính sách của Đảng và Nhà nước về xã hội hoá nghề rừng, tái cơ cấu ngành lâm nghiệp, quản lý chặt chẽ RTN, phát triển lâm nghiệp bền vững, góp phần tạo việc làm, tăng thu nhập và cải thiện sinh kế cho người làm nghề rừng.

\section{Giai đoạn 2016-2020:}

- Chương trình mục tiêu PTLN bền vũng giai đoạn 2016-2020 và Chương trình quốc gia về giảm phát thải khí nhà kính thông qua hạn chế mất và suy thoái rừng (REDD+) được phê duyệt, nhằm phát triển lâm nghiệp toàn diện theo chuỗi giá trị, đảm bảo bền vững cả về kinh tế, xã hội và môi trường gắn với thực hiện mục tiêu quốc gia về giảm phát thải khí nhà kính, tiến tới tiếp cận thị trường các - bon, tăng trưởng xanh, thu hút sự hỗ trợ của quốc tế, nâng cao đời sống của người dân và phát triển bền vững đất nước.

- Sau khi Luật Lâm nghiệp 2017 được Quốc hội thông qua, đến năm 2019 đã có 15 văn bản quy phạm pháp luật được ban hành để hướng dẫn thi hành Luật, tạo bước chuyển mới về chính sách lâm nghiệp (Trần 2020).

- Quyết định số 07/2012/QĐ-TTg đã phân cấp trách nhiệm quản lý nhà nước về rừng và đất lâm nghiệp đối với UBND các cấp; trong đó nhấn mạnh tầm quan trọng ở cấp huyện, cấp xã bởi đây là cấp quản lý trực tiếp tài nguyên rừng, quản lý việc giao đất, khoán rừng và kiểm soát quá trình sử dụng đất lâm nghiệp cho các chủ rừng trên địa bàn

Xây dựng cơ chế, chính sách tạo động lực thúc đẩy các thành phần kinh tế tham gia bảo vệ và phát triển rừng, khuyến khích các thành phần kinh tế trong và ngoài nước, cộng đồng dân cư thôn và hộ gia đình tham gia phát triển kinh tế lâm nghiệp
- Các BQL RĐD phát triển các dự án bảo đảm bảo tồn và quản lý bền vững nguồn tài nguyên (Quyết định số 186/QĐ-TTg năm 2010 của Thủ tướng Chính phủ và Nghị định số 117/2010/NĐ-CP về tổ chức và quản lý RĐD); phê duyệt Chương trình mục tiêu phát triển Lâm nghiệp bền vững giai đoạn 2016-2020 theo định hướng thị trường và đa dạng hoá các loại hình dịch vụ lâm nghiệp.

- Việt Nam và EU đã ký Hiệp định đối tác tự nguyện về thực thi luật lâm nghiệp, quản trị rừng và thương mại lâm sản (VPA/FLEGT) ngày 19/10/2018,tạo cơ hội mở rộng thị trường, cải thiện thể chế về quản lý rừng, giải quyết tình trạng khai thác và thương mại gỗ trái phép, góp phần phát triển bền vững ngành chế biến gỗ xuất khẩu của Việt Nam.

- Chính sách chi trả DVMTR theo Nghị định số 99/2010/NĐ-CP ngày 24/9/2010 của Chính phủ là một bước tiến mới có tính đột phá trong xây dựng và thực thi chính sách Lâm nghiệp: huy động các nguồn vốn xã hội cho phát triển ngành; góp phần cải thiện thu nhập cho hộ gia đình, cộng đồng (hộ nghèo và đồng bào dân tộc thiểu số) thông qua giao khoán bảo vệ rừng, giảm sức ép lên phá rừng và mất rừng. Thu nhập bình quân của các hộ gia đình nhận khoán bảo vệ rừng đạt 2 triệu đồng/hộ/năm. Ngoài ra, nguồn thu DVMTR góp phần tháo gỡ khó khăn cho 199 BQL, 84 Công ty lâm nghiệp trong bối cảnh đóng cửa RTN.

- Luật Lâm nghiệp 2017 đã thể chế hóa chủ trương xã hội hóa lâm nghiệp, xác định quyền và nghĩa vụ liên quan của các tổ chức và cá nhân được giao rừng và đất rừng. 
Bảng 13. Tiếp trang trước

\begin{tabular}{l} 
Khái quát chỉ tiêu, nhiệm \\
vụ của chương trình \\
\hline Tổ chức lại và nâng cao \\
hiệu lực của hệ thống \\
quản lý nhà nước về lâm \\
nghiệp theo hướng thống \\
nhất chức năng quản lý, \\
bảo vệ, sử dụng và phát \\
triển rừng; làm rõ chức \\
năng, nhiệm vụ của tổ \\
chức lâm nghiếp các cấp \\
và đa dạng hoá các loại \\
hình dịch vụ lâm nghiệp
\end{tabular}

Xây dựng cơ chế chính quốc doanh đã tổ chức, sắp xếp đổi mới thành công ty và hoạt động sản xuất, kinh doanh có hiệu quả, từng bước thực hiện cổ phần hoá các công ty kinh doanh lâm nghiệp, tạo điều kiện thuận lợi cho hoạt động sản xuất, kinh doanh theo cơ chế thị trường.

Xây dựng, thực hiện và mở rộng hình thức quản lý bảo vệ rừng cộng đồng. sách cho các lâm trường

\section{Kết quả đạt được}

- Trước năm 2019, hoạt động lâm nghiệp được thực hiện theo Luật Bảo vệ và Phát triển rừng 2004. Từ 2019 thực hiện theo Luật Lâm nghiệp.

- Việc nâng cao hiệu lực của hệ thống quản lý nhà nước về lâm nghiệp đã được cụ thể hóa trong từng giai đoạn, một số nội dung đáng chú ý bao gồm: Phân cấp trách nhiệm quản lý nhà nước về rừng và đất lâm nghiệp đối với Ủy ban nhân dân các cấp (Quyết định số 07/2012/QĐ-TTg phân cấp trách nhiệm quản lý nhà nước về rừng và đất lâm nghiệp ); Quy định chức năng, nhiệm vụ, quyền hạn và cơ cấu tổ chức của Bộ NN\&PTNT (Nghị định 199/2013/NĐ-CP ngày 26/11/2013 của Chính phủ quy định chức năng, nhiệm vụ, quyền hạn và cơ cấu tổ chức của Bộ NN\&PTNT); Kiện toàn tổ chức kiểm lâm, đảm bảo các điều kiện để Kiểm lâm thực hiện đầy đủ chức năng bảo vệ rừng, bổ sung chức năng phát triển rừng đối với Chi cục Kiểm lâm thành đầu mối cơ quan quản lý về lâm nghiệp tại địa phương; có đủ quyền hạn để thực hiện nhiệm vụ quản lý, bảo vệ rừng được giao thông qua việc tăng cường quản lý về chuyên môn, nghiệp vụ, vũ khí, công cụ hỗ trợ (Quyết định số 1920/QĐ-TTg ngày 24/10/2014 của Thủ tướng Chính phủ phê duyệt Đề án kiện toàn tổ chức, nâng cao năng lực, hiệu quả hoạt động của kiểm lâm giai đoạn 2014-2020); Sau này xác định Chi cục Kiểm lâm tại các tỉnh, thành phố trực thuộc Trung ương là cơ quan tham mưu quản lý Nhà nước về lâm nghiệp giúp Sở Nông nghiệp và PTNT tại địa phương (Nghị định số 01/2019/NĐ-CP của Chính phủ về Kiểm lâm và Lực lượng chuyên trách bảo vệ rừng).

- Thực hiện chủ trương xã hội hóa các hoạt động lâm nghiệp, khuyến khích và hỗ trợ thành lập các hội, hiệp hội về lâm nghiệp, ngoài các tổ chức đã có truyền thống từ lâu như Hội KHKT Lâm nghiệp Viêt Nam (VIFA), Hiệp hội Gỗ và Lâm sản Việt Nam (VIFORES) mà còn có các tổ chức mới thành lập như Hội Chủ rừng Việt Nam ${ }^{1}$

- Thực hiện việc đổi mới hệ thống tổ chức sản xuất kinh doanh lâm nghiệp, tổng số 256 lâm trường quốc doanh đã được sắp xếp, chuyển thành: 148 Công ty TNHH MTV lâm nghiệp do nhà nước làm chủ sở hữu, 03 công ty cổ phần, $91 \mathrm{BQL}$ rừng phòng hộ, giải thể 14 lâm trường.

- Đến 2019, có 136 công ty lâm nghiệp tiếp tục được sắp xếp đạt kết quả như sau: chuyển thành công ty TNHHMTV $100 \%$ vốn nhà nước thực hiện nhiệm vụ sản xuất kinh doanh $3 / 3$ công ty; chuyển thành Công ty TNHH MTV 100\% vốn Nhà nước thực hiện nhiệm vụ công ích $59 / 60$ công ty; cổ phần hóa $9 / 30$ công ty; chuyển thành công ty TNHH hai thành viên trở lên $8 / 22$ công ty ; chuyển thành Ban quản lý rừng $5 / 5$ công ty; giải thể $9 / 16$ công ty.

- Quyết định số 07/2012/QĐ-TTg đã tạo khung pháp lý cho việc thực hiện đồng quản lý rừng, chia sẻ lợi ích, quyền và nghĩa vụ của Ban quản lý RĐD và cộng đồng địa phương nhằm góp phần tạo thu nhập và cải thiện sinh kế cho cộng đồng dân cư gắn với giao khoán bảo vệ rừng;

- Quyết định số 24/2012/QĐ-TTg về Chính sách đầu tư phát triển RĐD giai đoạn 20112020 đã quy định hỗ trợ các cộng đồng vùng đệm các khu RĐDvà cho phép sử dụng cũng như cho thuê môi trường RĐD để phát triển du lịch sinh thái

Thiết lập hệ thống khuyến lâm nhà nước các cấp và có cơ chế hỗ trợ tổ chức khuyến lâm tự nguyện cho thôn, xã có nhiều rừng.
- Trên cơ sở Đề án phát triển khuyến lâm giai đoạn 2008-2010 và định hướng đến 2020 được Bộ Nông nghiệp và PTNT ban hành tại Quyết định số 832/QĐ-BNN-KHCN ngày 17/3/2008, hệ thống khuyến lâm được hình thành từ trung ương đến địa phương đã góp phần nâng cao năng lực của người dân và các chủ rừng, bước đầu hình thành mối liên kết giữa nhà quản lý, nhà khoa học, chủ doanh nghiệp và các chủ rừng ở một số vùng và chuỗi sản phẩm. 
Bảng 13. Tiếp trang trước

\section{Khái quát chỉ tiêu, nhiệm Kết quả đạt được
vụ của chương trình}

Xây dựng các đơn vị chuyên trách về giám sát, đánh giá gắn với việc kiện toàn hệ thống lập kế hoạch lâm nghiệp các cấp.
Thực hiện Dự án “Tổng điều tra, kiểm kê rừng toàn quốc giai đoạn 2013-2016" theo Quyết định số 594/QĐ-TTg ngày 15/4/2013 của Thủ tướng Chính phủ, Thông tư số 12/2014/ TTLT-BTC-BNNPTNT ngày 24/01/2014; Quyết định số 1157/QĐ-BNN-TCLN ngày 26/5/2014 của Bộ NN\&PTNT; kết quả dự án đã xây dựng và cập nhật cơ sở dữ liệu tài nguyên rừng trên cả nước, phục vụ công tác theo dõi, giám sát tài nguyên rừng và quản lý, phát triển lâm nghiệp.

Xây dựng hệ thống giám sát, đánh giá gắn với lập kế hoạch lâm nghiệp: Hệ thống thông tin quản lý ngành lâm nghiệp (FORMIS) đã thiết lập được một hệ thống nền cho phép xây dựng cơ sở dữ liệu tài nguyên rừng trong cả nước tích hợp với kết quả chương trình tổng điều tra, kiểm kê rừng và các dữ liệu cập nhật diễn biến rừng, dữ liệu tiềm năng về REDD+ , dữ liệu giống cây trồng lâm nghiệp, dữ liệu chi trả dịch vụ môi trường rừng,... Hệ thống Giám sát và theo dõi diễn biến rừng (FMS) được xây dựng với sự hỗ trợ của các tổ chức quốc tế (USAID, CIFOR, GIZ,..) đã kết nối tự động tới công cụ phát hiện thay đổi rừng từ ảnh vệ tinh đồng thời gửi tới cơ quan Kiểm Lâm và các chủ rừng lớm; hẹ thống còn tích hợp dữ liệu về ranh giới, quy hoạch 3 loại rừng, hiện trạng rừng, có thể theo dõi diễn biến rừng một cách trực quan và dễ dàng (Trần ĐN 2020).

1 Được thành lập theo Quyết định số 2905/QĐ-BNV ngày 22/8/2016, Bộ Nội vụ, đây là một tổ chức xã hội - nghể nghiệp đại diện cho khoảng 1,5 triệu hộ gia đình, 10.000 cộng đông dân cư thôn bản được giao rừng và hàng trăm BQLRĐD, RPH và các Công ty Lâm nghiệp; nhằm tập hợp, hỗ trợ, giúp đỡ nhau trong quản trị rừng, thực hiện quyền và nghĩa vụ của chủ rừng, góp phần vào phát triển lâm nghiệp.

Nguồn: Danh mục một số văn bản chính sách, pháp luật về Lâm nghiệp giai đoạn 2006-2020 xem Phụ lục 5.

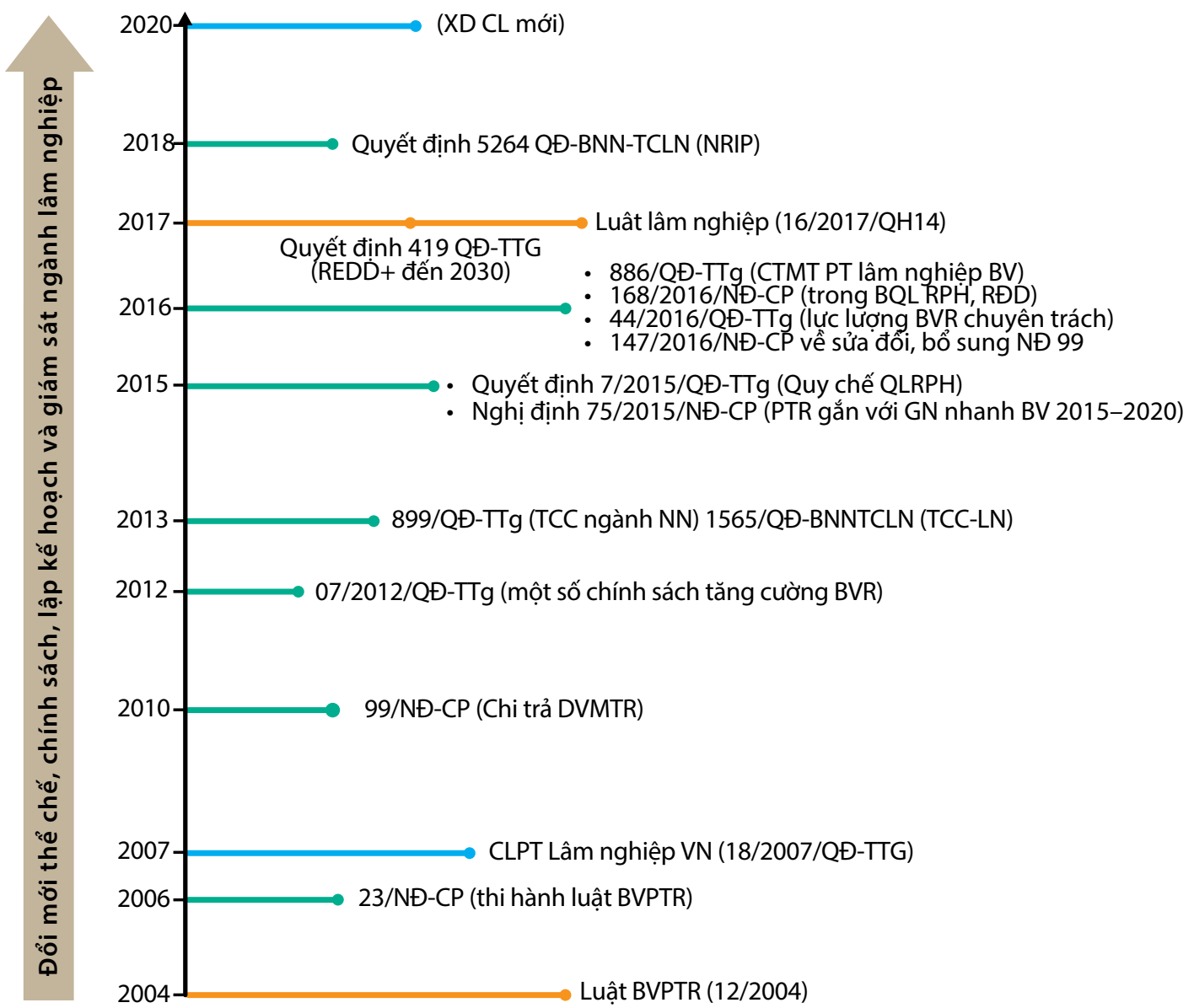

Hình 12. Một số mốc xây dựng chính sách lâm nghiệp giai đoạn 2004-2020 


\section{Kết quả huy động nguồn lực thực hiện chiến lược}

Tài chính bền vững là yếu tố quan trọng để thực hiện chiến lược hiệu quả. Bảng 14 cho thấy ngành lâm nghiệp Việt Nam đã huy động nguôn lực thực hiện chiến lược thành công và vượt mức kì vọng.

Từ năm 2010 đến nay, Nhà nước đã ban hành nhiều chính sách đâu tư theo hướng nâng mức hỗ trợ cho công tác BVPTR; Ví dụ: Khoán quản lý bảo vệ rừng tăng từ 100.000 đồng/ha/năm (năm 2006) lên 200.000 đồng/ha/năm (Quyết định số 60/2010/QĐ-TTg ngày 20/9/2010), sau đó lên bình quân 300.000 đồng/ha/năm (Quyết định số 38/2016/QĐ-TTg ngày 14/9/2016) và với các xã tại khu vực I, II lên 400.000 đồng/ha (Nghị định số 75/2015/NĐ-CP ngày 09/9/2015); khu vực ven biển gấp 1,5 lần mức khoán bình quân (Nghị định 119/2016/NĐ-CP ngày 23/8/2016).

Kết quả nghiên cứu của Phạm và cộng sự (2018) cho thấy rằng, ngân sách nhà nước, bao gồm cả ngân sách trung ương và địa phương, chỉ chiếm $21,5 \%$ tổng nguôn vốn huy động và đạt $97 \%$ so với kế hoạch đặt ra; được phân bổ chủ yếu cho trông rừng. Mặc dù không đạt mục tiêu ban đâu, nhưng việc tăng nguồn đầu tư từ ngân sách nhà nước theo thời gian đã phản ánh sự quan tâm của Chính phủ đối với ngành lâm nghiệp; đây là nguôn tài chính chủ đạo ở các tỉnh nghèo, nơi huy động ngân sách ngoài quốc doanh là rất nhỏ. Từ năm 2006 đến 2010, nguôn huy động từ các tổ chức, cá nhân và hộ gia đình chiếm hơn $30 \%$ và giai đoạn 2011-2016 tăng lên 48\% đâu tư tài chính ngành lâm nghiệp. Chi trả DVMTR chiếm $22 \%$ tổng ngân sách lâm nghiệp và đóng một vai trò quan trọng trong việc chi trả chi phí bảo vệ rừng. Đầu tư ngoài ngân sách nhà nước ngày càng tăng chứng tỏ chính sách xã hội hoá lâm nghiệp đã bước đầu thành công. Tuy nhiên, hiệu quả và hiệu suất đầu tư hiện tại vào lâm nghiệp còn thấp và phân tán, dữ liệu về tài chính lâm nghiệp không thống nhất và không được thu thập một cách có hệ thống gây ra những thách thức lớn cho việc đưa ra một bức tranh toàn diện về tài chính lâm nghiệp. Những khoảng trống thông tin cân được giải quyết trong tương lai bởi một hệ thống theo dõi tài chính lâm ghiệp quốc gia minh bạch và có trách nhiệm giúp các nhà hoạch định chính sách cải thiện kế hoạch tài chính cho ngành, cũng như hướng tới mục tiêu các nguôn tài chính cho lợi nhuận lớn hơn (Phạm và cộng sự 2018c).

Phạm và cộng sự (2018a) cũng nhấn mạnh vai trò của các ngu ồ tài chính mới đặc biệt là REDD+ trong bối cảnh của Việt Nam. Nhóm tác giả cho rằng REDD+ có tiềm năng lớn trong việc tạo lập và đóng góp tài chính để hỗ trợ cho ngành lâm nghiệp ở Việt Nam. Tuy nhiên, việc giảm cả nguồn vốn và sự cam kết tài trợ cho REDD+, thách thức trong việc đáp ứng các yêu cầu của nhà tài trợ, khó khăn để đảm bảo yêu câu về nguôn tài chính cân có giúp thực hiện chương trình REDD+ quốc gia cho thấy tiềm để REDD+ trở thành nguôn đóng góp chính cho ngành lâm nghiệp còn hạn chế. Chính phủ Việt Nam đã xác định các nguồn tài trợ cho các giai đoạn thực thi chương trình REDD+ có thể đến từ khu vực tài chính công hoặc tư nhân. Ngoài ra trong thực tế, nguôn tài chính cho REDD+ ở Việt Nam vấn chủ yếu đến từ các nhà tài trợ quốc tế, sự đóng góp tài chính từ ngân sách nhà nước và tư nhân vẫn còn hạn chế. Cho tới nay, nguôn tài chính REDD+ được sử dụng phân tán không có sự phối hợp giữa các bên bởi các vấn đề ưu tiên của REDD+ tại Việt Nam chưa được xác định rõ ràng. Thực hiện và nâng cao tính hiệu quả và hiệu ích các hoạt động REDD+ ở Việt Nam đang gặp nhiêu khó khăn bởi: dũ̃ liệu tài chính vê REDD+ tại Việt Nam còn thiếu và chưa chính xác; định nghĩa rõ ràng về tài chính cho REDD+ chưa được xác định; hệ thống giám sát tài chính REDD+ quốc gia còn thiếu; và năng lực kỹ thuật hạn chế (trong cả tổ chức chính phủ và xã hội dân sự) liên quan đến giám sát tài chính REDD+. Để tăng tiềm năng vê đóng góp tài chính của REDD+ cho 
Bảng 14. Kết quả huy động nguồn lực thực hiện chiến lược

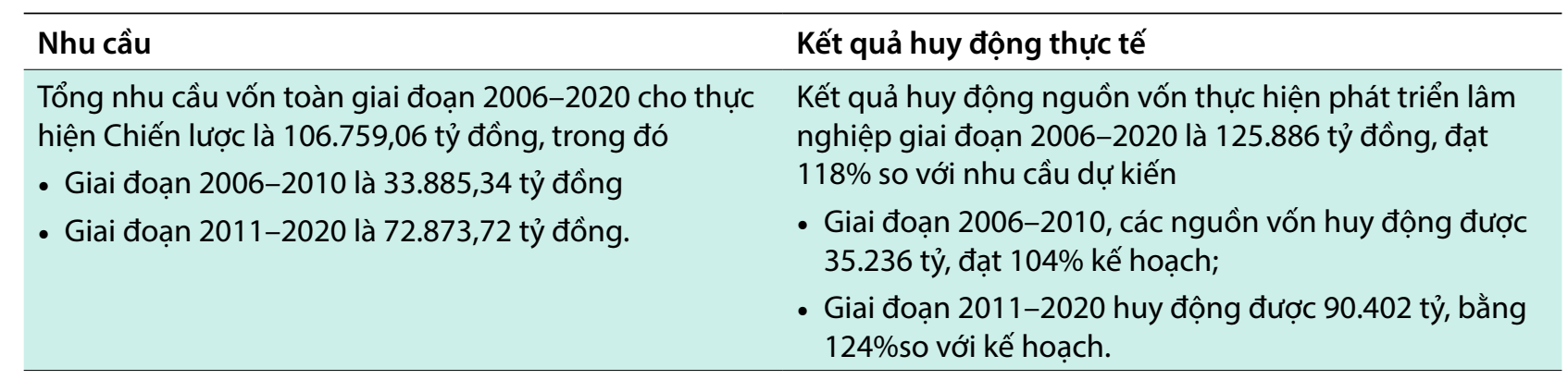

Nguồn: Tác giả tự tổng hợp từ tài liệu của Tổng cục lâm nghiệp, 2020

ngành lâm nghiệp ở Việt Nam, cần phải: có sự phối hợp tốt hơn giữa các ngành, giữa các nhà tài trợ và các cơ quan chính phủ; nâng cao năng lực các cơ quan chính phủ và tổ chức xã hội dân sự trong giám sát và quản lý nguồn tài chính REDD+, phát triển và thực hiện hiệu quả các chính sách và biện pháp REDD+ để chính phủ có thể tiếp cận chi trả dựa vào kết quả từ nhiêu nguôn tài trợ quốc tế khác nhau.

Tại cấp tỉnh, nguôn tài chính dành cho công tác bảo vệ rừng đến từ 6 nguôn chính: ngân sách trung ương; ngân sách tỉnh; chương trình quốc gia về chi trả dịch vụ môi trường rừng; các dự án quốc tế; vốn đối tác công-tư kết hợp; và từ khu vực tư nhân (Phạm và cộng sự 2019a). Sự cộng hưởng của các nguôn tài chính này đã khuyến khích chính quyển cấp tỉnh và các chủ rừng và các cơ quan nhà nước cấp tỉnh thực hiện tốt hơn công tác bảo vệ và phát triển rừng. Tuy nhiên, các chủ rừng vẫn gặp nhiều khó khăn trong việc tiếp cận các nguôn kinh phí này do các thủ tục xin cấp vốn còn phức tạp trong khi yêu cầu cần có kinh phí đối ứng cũng như chi phí đầu tư ban đầu khá cao để đáp ứng các tiêu chí tiếp cận các nguôn vốn(Phạm và cộng sự 2019a). 


\section{Bài học kinh nghiệm rút ra từ quá trình thực hiện chiến lược phát triển lâm nghiệp 2006-2020}

Kết quả thực hiện Chiến lược giai đoạn 20062020 cũng cho thấy ngành lâm nghiệp đã đạt được phân lớn các chỉ tiêu vê kinh tế nhửng thách thức đặt ra nằm ở việc thực hiện và đạt được kì vọng ở các mục tiêu xã hội và môi trường. Để đạt được thành tựu như hiện nay là nhờ cam kết chính trị mạnh mẽ của chính phủ. Chiến lược đã được triển khai trên phạm vi toàn quốc với sự vào cuộc của cả hệ thống chính trị từ Trung ương đến địa phương, thông qua các chương trình đê án quan trọng cấp quốc gia, vì vậy đã đạt được nhiều kết quả tốt, tỷ lệ che phủ rừng liên tục tăng, nhận thức xã hội vê lâm nghiệp được nâng cao. Hệ thống văn bản quy phạm pháp luật đã thể chế hoá kịp thời các chủ trương, chính sách của Đảng và Nhà nước vê lâm nghiệp, tạo khung pháp lý để các cấp, các ngành tổ chức thực hiện phát triển lâm nghiệp.Việc không đạt được nhiêu chỉ tiêu môi trường và xã hội có nhiều nguyên nhân (Bảng 15).

Một số hạn chế, tồn tại trong phát triển lâm nghiệp giai đoạn 2006-2020 được thể hiện trong báo kết quả thực hiện chiến lược phát triển lâm nghiệp giai đoạn 2006-2020 của 49 tỉnh được tổng hợp trong Bảng 16. Bảng 16 chỉ rõ khó khăn trong đảm bảo nguôn vốn (87,5\%), tính phức tạp của tình hình vi phạm lâm luật $(68,7 \%)$ và hệ thống chính sách chưa hoàn thiện, chưa phù hợp thực tiễn, số lượng văn bản nhiêu nhưng còn chồng chéo, chưa thống nhất và hiệu quả thực thi thấp; một số chính sách bất cập nhưng chậm được điều chỉnh $(64,6 \%)$, và chính sách giao đất giao rừng chưa hiệu quả là 4 khó khăn chủ chốt trong việc thực hiện Chiến lược.

\section{Bảng 15. Nguyên nhân}

\begin{tabular}{|c|c|}
\hline Nguyên nhân & Lí giải \\
\hline \multirow{5}{*}{$\begin{array}{l}\text { Chính trị, Thể chế } \\
\text { chính sách }\end{array}$} & - Công tác quy hoạch và quản lý quy hoạch còn hạn chế \\
\hline & $\begin{array}{l}\text { - Theo các bên phỏng vấn, tình trạng vi phạm các quy định về bảo vệ rừng diễn ra } \\
\text { phức tạp bới trong thực tế vẫn còn trường hợp chặt phá, khai thác rừng trái phép, } \\
\text { cháy rừng, xâm lấn rứng, chống người thi hành công vụ }\end{array}$ \\
\hline & - Chính phủ thiếu kiên quyết áp dụng chế tài đủ mạnh mẽ \\
\hline & $\begin{array}{l}\text { - Địa phương chưa thực hiện đầy đủ trách nhiệm quản lý, năng lực cán bộ hạn chế, } \\
\text { chưa đủ điều kiện phát huy vai trò địa phương }\end{array}$ \\
\hline & - Chính sách chưa hoàn thiện, không cụ thể, một số thiếu thực tế \\
\hline \multirow[t]{2}{*}{ Kĩ thuật } & - Quản lý rừng, chất lượng giống chưa chặt chẽ \\
\hline & - Hệ thống Tiêu chuẩn, quy chuẩn kỹ thuật chưa đầy đủ \\
\hline \multirow[t]{4}{*}{ Xã hội } & $\begin{array}{l}\text { - Nhận thức về lâm nghiệp chưa toàn diện về giá trị rừng, quan hệ lâm nghiệp và KT- } \\
\text { XH, các nhu câuu với lâm nghiệp trong thời kỳ hội nhập và BĐKH... }\end{array}$ \\
\hline & - Nhu cầu về các sản phẩm quý hiếm từ rừng vẫn tồn tại và có lợi nhuận cao \\
\hline & - Mật độ dân số cao gây sức ép lên rừng do thiếu đất sản xuất \\
\hline & - Công tác tuyên truyền, giáo dục hạn chế \\
\hline
\end{tabular}


Bảng 15. Tiếp trang trước

\begin{tabular}{|c|c|}
\hline Nguyên nhân & Lí giải \\
\hline Tài chính/Kinh tế & $\begin{array}{l}\text { - Cơ sở vật chất còn bất cập } \\
\text { - Nguồn vốn Nhà nước cho lâm nghiệp thấp hơn so với nhu cầu } \\
\text { - Chưa có chính sách , cơ chế hấp dẫn nhà đầu tư } \\
\text { - Môi trường đầu tư hạn chế, tiềm năng lâm nghiệp chưa đạt được nhiều sự quan tâm } \\
\text { - Nguyên nhân phá rừng và suy thoái rừng gắn liền với các mục tiêu phát triển kinh } \\
\text { tế, cơ sở hạ tấng đòi hỏi có sự liên kết giữa các ngành chặt chẽ. Nhu cẩu sử dụng đất } \\
\text { để phát triển các ngành kinh tế khác dẫn đến quy hoạch thiếu ổn định và thường bị } \\
\text { điêuu chînh } \\
\text { - Thu nhập từ nghề rừng còn hạn chế chưa tạo động lực kinh tế cho người dân và } \\
\text { cộng đồng tích cực tham gia }\end{array}$ \\
\hline Điều kiện tự nhiên & $\begin{array}{l}\text { - Rừng phân bố trên phạm vi rộng, địa hình bị chia cắt, ở các vùng KT-XH khó khăn } \\
\text { - Biến đổi khí hậu } \\
\text { - Chất lượng rừng thấp, chưa đáp ứng yêu cầu về nguyên liệu cho công nghiệp chế } \\
\text { biến và xuất khẩu } \\
\text { - Chu kỳ sản xuất cây lâm nghiệp dài, nhiều rủi ro, tính cạnh tranh thấp }\end{array}$ \\
\hline Năng lực & $\begin{array}{l}\text { - Nguồn nhân lực còn thiếu và yếu, cả nhân lực kỹ thuật và quản lý } \\
\text { - Cơ sở vật chất, kỹ thuật còn nghèo, lạc hậu } \\
\text { - Nguồn lực tài chính hạn chế, thiếu so với nhu cầu }\end{array}$ \\
\hline
\end{tabular}

Bảng 16. Hạn chế, tồn tại trong phát triển lâm nghiệp giai đoạn 2006-2020 của địa phương

\begin{tabular}{|c|c|c|}
\hline TT & Nội dung tồn tại, hạn chế & $\begin{array}{l}\text { Tỷ lệ số tỉnh đề cập tới nội dung này } \\
\text { (\%) }\end{array}$ \\
\hline 1 & $\begin{array}{l}\text { Nguồn vốn ngân sách Nhà nước còn thấp so với yêu cầu } \\
\text { nhiệm vụ đề ra, cơ cấu đâu tư chưa cân đối chưa quan tâm } \\
\text { đâu tư xây dựng cơ sở hạ tầng lâm nghiệp. }\end{array}$ & 87,5 \\
\hline 2 & Tình hình vi phạm pháp luật lâm nghiệp còn phức tạp & 68,7 \\
\hline 3 & $\begin{array}{l}\text { Hệ thống chính sách lâm nghiệp chưa hoàn thiện, chưa } \\
\text { phù hợp thực tiễn, số lượng văn bản nhiều nhưng còn } \\
\text { chồng chéo, chưa thống nhất và hiệu quả thực thi thấp; } \\
\text { Một số chính sách bất cập nhưng chậm được điều chỉnh }\end{array}$ & 64,6 \\
\hline 4 & $\begin{array}{l}\text { Thực hiện chính sách Giao đất giao rừng, khoán bảo vệ } \\
\text { rừng để thực hiên xã hội hóa lâm nghiệp còn nhiểu khó } \\
\text { khăn, phức tạp, tiến độ chậm và chưa hiệu quả; }\end{array}$ & 53,5 \\
\hline 5 & Cơ sở hạ tầng lâm nghiệp thấp kém & 52,1 \\
\hline 6 & $\begin{array}{l}\text { Công tác quy hoạch } 3 \text { loại rừng và sử dụng đất lâm nghiệp } \\
\text { chưa sát với thực tế, chậm được điểu chỉnh và thường bị } \\
\text { phá vỡ; Ranh giới rừng trên bản đồ và trên thực địa chưa rõ } \\
\text { ràng; việc lấn chiếm, tranh chấp đất đai diễn ra phức tạp }\end{array}$ & 44,2 \\
\hline 7 & Đóng mốc ranh giới rừng chậm & 39,6 \\
\hline 8 & $\begin{array}{l}\text { Quản lý Nhà nước về Lâm nghiệp còn hạn chế, chưa kiên } \\
\text { quyết chỉ đạo, kiểm tra, việc thực hiện pháp luật và chính } \\
\text { sách lâm nghiệp; chưa xử lý nghiêm các hành vi vi phạm } \\
\text { pháp luật vể bảo vệ và phát triển rừng }\end{array}$ & 39,5 \\
\hline
\end{tabular}

Nguồn: Tác giả tổng hợp từ báo cáo của các tỉnh, 2020. 


\section{8 Đề xuất cho chiến lược phát triển 2021-2030 tầm nhìn 2050}

\subsection{Tiệm cận với xu thế phát triển lâm nghiệp trên thế giới}

Chiến lược phát triển lâm nghiệp giai đoạn 2021-2030 tầm nhìn 2050 ngoài việc cân tiếp thu các bài học trong quá trình thực hiện chiến lược giai đoạn cũ, đón đâu xu thế phát triển thế giới (Hộp 4) và xem xét cẩn trọng trong bối cảnh của Việt Nam (Hộp 5).

\section{Hộp 4. Xu thế thế giới tới năm 2030}

Trong 10 năm tới tình hình khu vực và thế giới diễn biến nhanh chóng, phức tạp và khó lường. Hòa bình, hợp tác và phát triển vẫn là xu thế lớn nhưng cạnh tranh chiến lược, xung đột cục bộ tiếp tục diễn ra phức tạp và gay gắt hơn. Toàn cầu hóa và hội nhập quốc tế tiếp tục tiến triển nhưng gặp nhiều trở ngại, thách thức. Cạnh tranh chiến lược, chiến tranh thương mại, tranh giành các nguồn tài nguyên, thị trường, công nghệ, nhân lực chất lượng cao giữa các nước ngày càng quyết liệt. Các dòng vốn ODA sẽ giảm đi, vốn FDI sẽ tăng lên, hướng tới những vùng lãnh thổ có môi trường đầu tư thuận lợi và các ngành sản xuất đem lại hiệu quả kinh tế cao.

Nhiều vấn đề toàn cầu liên quan đến tài nguyên rừng và Lâm nghiệp sẽ diễn biến phức tạp như Biến đổi khí hậu và cạn kiệt tài nguyên: hơn $50 \%$ dân số toàn cầu vào năm 2030 sẽ thiếu nước liên tục, độ đa dạng loài sẽ giảm $10 \%$ vào năm 2050 và các khu rừng già sẽ bị giảm $13 \%$ trên toàn cầu; Phát thải $K N K$ tăng $50 \%$ và nhiệt độ trái đất có thể tăng từ 30-60 độ $C$ vào năm 2050, nguy cơ cháy rừng và dịch bệnh lan rộng; Năng lượng sinh học sẽ phát triển mạnh trước nhu cầu thực hiện các cam kết về ứng phó với BĐKH. Thị trường carbon thế giới và nội địa sẽ tăng nhanh và vận hành trên diện rộng với sự hỗ trợ của KHCN làm giảm chi phí đo đếm, thẩm định và giao dịch thương mại. Một số xu thế mới về phát triển kinh tế trên cơ sở sử dụng một cách thông minh các tài nguyên sinh học có khả năng tái tạo và thân thiện với môi trường được chú ý, đặc biệt là Châu Âu như: Kinh tế sinh học; Kinh tế tuần hoàn và Kinh tế chiếc bánh vòng (Phạm và cộng sự 2020c).

Đến năm 2030, dân số thế giới có thể đạt 9 tỉ người, thị dân chiếm $60 \%$ và nhóm trung lưu ngày càng tăng; nhu cầu thực phẩm an toàn và môi trường sống xanh, sạch, đẹp, cải thiện sức khỏe con người ngày càng tăng, thúc đẩy phát triển Lâm nghiệp đô thị và nâng cao vai trò của ngành lâm nghiệp trong đảm bảo an sinh xã hội, y tế và nghỉ dưỡng.

Sự phát triển nhanh chóng của Khoa học công nghệ, đặc biệt là công nghệ sinh học và cách mạng công nghiệp 4.0 tạo đột phá trên nhiều lĩnh vực, mang lại thời cơ và thách thức cho mọi ngành, lĩnh vực ở tất cả các quốc gia. Phát triển kinh tế - xã hội chuyển từ dựa vào tài nguyên thiên nhiên sang dựa vào KHCN như: công nghệ thông tin, $5 \mathrm{G}$, công nghệ tự động hóa,... Trong một bối cảnh thay đổi nhanh chóng và đa dạng, ngành Lâm nghiệp sẽ phải xây dựng các giải pháp tối ưu hóa, đầu tư công nghệ, đầu tư nhân lực và chất xám, phát triển các giá trị gia tăng và các sản phẩm mới, các vật liệu, sản phẩm thân thiện với môi trường, thay thế gỗ hay kết hợp gỗ với các loại vật liệu khác như nhựa, giấy, kim loại,... Các doanh nghiệp Lâm nghiệp sẽ hướng vào phát triển thương mại giá trị cao, chuyển từ tập trung vào khối lượng sang tập trung vào giá trị sản phẩm tạo ra để tăng thu nhập từ giá trị gia tăng. Nhu cầu số hóa, các phần mềm ứng dụng và tự động hóa cho ngành lâm nghiệp và các dịch vụ hỗ trợ, logistic, chăm sóc khách hàng trong lâm nghiệp sẽ gia tăng. 


\section{Hộp 4. Tiếp trang trước}

Một số vấn đề đặt ra cần giải quyết từ năm 2020: Ảnh hưởng của đại dịch Covid-19 làm kinh tế thế giới tăng trưởng chậm lại, tiềm ẩn nguy cơ khủng hoảng và suy thoái. Chiến tranh thương mại giữa các cường quốc sẽ tác động mạnh đến các ngành năng lượng, gỗ và giấy. Nhu cầu sản xuất giấy sẽ giảm do phát triển truyền thông điện tử, nhu cầu gỗ xẻ, gỗ xây dựng tăng do xây dựng nhà cửa ngày càng tăng. Cùng với sự thay đổi nhanh chóng của môi trường kinh doanh và thị trường sản phẩm gỗ, một số xu hướng phát triển Lâm nghiệp trên thế giới cần chú ý là: Lâm nghiệp đô thị; LSNG; đa dạng hóa sản phẩm với tỷ lệ ngày càng tăng các sản phẩm chế biến sâu, giá trị gia tăng cao; Thị trường và Thương mại phát thải ; Phát triển thuế và thuế giá trị gia tăng của hệ sinh thái rừng; Phát triển thị trường chứng khoán, cổ phiếu và trái phiếu rừng.

Đặc biệt, vai trò Lâm nghiệp ngày càng gia tăng đối với an sinh xã hội, Y tế, xóa đói giảm nghèo và ứng phó với $B \boxminus K H$ đang ngày được thế giới ghi nhận.

Nguồn: Phạm và Lê 2020, Phạm và cộng sự 2019b, Phạm và cộng sự 2019

\section{Hộp 5. Tình hình phát triển của Việt Nam trong giai đoạn 20 năm trở lại đây}

Sau 35 năm đổi mới, nước ta đã đạt nhiều thành tựu quan trọng trong phát triển kinh tế - xã hội; tăng trưởng kinh tế khá cao và ổn định; mức sống của người dân được cải thiện; chất lượng nguồn nhân lực có những chuyển biến tích cực; hệ thống luật pháp ngày càng hoàn thiện; Thế và lực của đất nước, sức mạnh tổng hợp quốc gia, uy tín quốc tế ngày càng nâng cao. Trong giai đoạn tới, Việt Nam tiếp tục hội nhập quốc tế ngày càng sâu, rộng hơn với nhiều thuận lợi đồng thời với những khó khăn thách thức mới đan xen và khó dự báo.

Nền kinh tế phát triển tuy khá nhanh nhưng chưa bền vững, chất lượng và hiệu quả tăng trưởng còn thấp; năng lực cạnh tranh yếu; hiệu quả sử dụng đất đai còn thấp; chuyển dịch cơ cấu sản xuất chậm; chất lượng nguồn nhân lực chưa đáp ứng yêu cầu phát triển, khoa học và công nghệ chưa thành động lực cho phát triển; hệ thống pháp luật chưa đầy đủ và đồng bộ. Một số nguy cơ còn gay gắt hơn như bẫy thu nhập trung bình, $\mathrm{B} \boxminus \mathrm{KH}$, chất lượng dân số còn thấp và xu hướng già hóa dân số nhanh là các thách thức lớn trong giai đoạn tới.

Gia tăng dân số. Dân số Việt Nam năm 2020 hơn 97 triệu người, chiếm 1,25\% dân số thế giới và đứng thứ 15 trên thế giới với mật độ 313 người/km2 và tuổi trung bình 32,5 tuổi. Đến năm 2030 dự kiến tăng lên 104 triệu người, tuổi thọ trung bình là 75; Xu hướng biến đổi cơ cấu dân số theo hướng già đị; Dự báo Việt Nam sẽ trở thành nước có dân số già vào năm 2038 với tỷ lệ người từ 60 tuổi trở lên đạt trên 20\%, đến năm 2049, tỷ lệ người cao tuổi sẽ chiếm khoảng $25 \%$ dân số, tức là 4 người dân có một người cao tuổi.

Cam kết chính trị mạnh mẽ về vai trò của ngành lâm nghiệp. Đảng và Chính phủ luôn có quan điểm, định hướng nhất quán và xuyên suốt về vai trò quan trọng của rừng và ngành Lâm nghiệp đối với sự phát triển bền vững của đất nước, bảo vệ môi trường và ứng phó với $B \boxminus K H$, góp phần bảo đảm an sinh xã hội, xóa đói giảm nghèo và quốc phòng an ninh. Độ che phủ rừng là một chỉ tiêu quốc gia quan trọng.

Giá trị sản xuất lâm nghiệp tiếp tục tăng trưởng ổn định; Kim ngạch xuất khẩu sản phẩm gỗ và LSNG duy trì tăng trưởng ở mức cao, đặc biệt ở những thị trường truyền thống. Các doanh nghiệp lâm nghiệp chuyển đổi cơ cấu sản xuất kinh doanh vào những sản phẩm chính, nhu cầu số lượng lớn và bền vững; Doanh nghiệp có vốn đầu tư nước ngoài (FDI) vào ngành gỗ và số doanh nghiệp tham gia xuất khẩu có xu hướng tăng. Phát triển mạnh nguồn nguyên liệu từ $R T$ trong nước, đáp ứng ngày càng tốt hơn nhu cầu nguyên liệu cho công nghiệp chế biến gỗ và xuất khẩu. 


\section{2 Đề xuất của địa phương về phát triển lâm nghiệp giai đoạn tới}

Một số nội dung đề xuất được tổng hợp từ 49 Báo cáo của các tỉnh được tổng hợp trong việc xây dựng Chiến lược lâm nghiệp giai đoạn 20212030, tầm nhìn 2050 được thể hiện trong Hình 13.

Hình 13 cho thấy, các đề xuất của địa phương liên quan đến việc xây dựng ưu tiên cho xây dựng Chiến lược chủ yếu tập trung vào việc nâng cao cơ sở hạ tâng, nâng cao mức đâu tư trông rừng và xây dựng các chính sách lâm nghiệp phù hợp với vùng miền.

\subsection{Tiếp cận đa ngành và toàn diện}

Nhóm tác giả dựa vào kết quả phỏng vấn, rà soát và phân tích các vấn đề ưu tiên khác cân được xem xét dưới đây.

Phát triển lâm nghiệp giai đoạn 2021-2030, tầm nhìn 2050 theo hướng đổi mới mô hình tăng trưởng từ dựa vào mở rộng diện tích, khối lượng và nguôn lực sang tập trung vào giá trị sản phẩm tạo ra để tăng thu từ giá trị gia tăng dựa vào năng suất, chất lượng và hiệu quả. Trước bối cảnh thế giới và Việt Nam, cần xây dựng Lâm nghiệp Việt Nam thực sự trở thành một ngành kinh tế, kỹ thuật hiện đại và sáng tạo; phát triển bền vững theo chuỗi giá trị, phù hợp cơ chế thị trường và hội nhập quốc tế sâu rộng, có vị thế quan trọng trong trong phát triển KT-XH của đất nước, góp phân xây dựng thành công mô hình xã hội thịnh vượng/phôn vinh. Cần thúc đẩy phát triển lâm nghiệp theo chuỗi giá trị thông qua khuyến khích phát triển các mô hình liên kết sản xuất theo chuỗi giá trị giữa chủ rừng với doanh nghiệp chế biến và thương mại lâm sản.

Quy hoạch đất rừng và giao đất giao rừng. Hiện nay, Bộ NN-PTNT đang thực hiện nhiệm vụ được Chính phủ giao về lập quy hoạch Lâm nghiệp quốc gia thời kỳ 2021-2030, tầm nhìn đến 2050 theo Quyết định số $995 / \mathrm{Q} Đ-\mathrm{TTg}$ ngày 09/8/2018 của Thủ tướng Chính phủ giao nhiệm vụ cho các Bộ tổ chức lập quy hoạch ngành quốc gia thời kỳ 2021-2030, tầm nhìn đến 2050; trong nhiệm vụ này cần rà soát quy hoạch sử dụng 16,24 triệu ha rừng và đất lâm nghiệp được giao cho ngành Lâm nghiệp quản lý theo Nghị quyết của Quốc hội theo Nghị quyết số 134/2016/QH13 ngày 09/4/2016 của Quốc hội khóa XIII về điêu chỉnh quy hoạch sử dụng đất đến năm 2020 và kế hoạch sử dụng đất kỳ cuối (2016-2020) cấp quốc gia; hướng tới lâm phận quốc gia ổn định. Định hướng quy hoạch, phát triển hệ thống 3 loại rừng được thể hiện trong Hình 14. Rừng và đất rừng là tư liệu sản xuất cốt lõi của ngành lâm nghiệp. Công tác giao đất gắn với giao rừng cân được coi trọng và tiếp tục rà soát, bảo đảm thống nhất
Cần có chính sách đặc thù cho Lâm nghiệp, chính sách cần phù hợp với đặc điểm của các vùng miền.

Tăng suất đầu tư cho các hoạt động lâm nghiệp: trồng rừng, bảo vệ rừng, làm giàu rừng tự nhiên

Tăng cường đầu tư trang bị cho công tác bảo vệ rừng, bao gồm trang thiết bị PCCCR, trang bị cho lực lượng BVR chuyên trách và Kiểm lâm;

Tăng cường đầu tư nâng cấp cơ sở hạ tầng Lâm nghiệp, bao gồm làm đường, vườn ươm giống công nghệ cao, biển báo, mốc giới

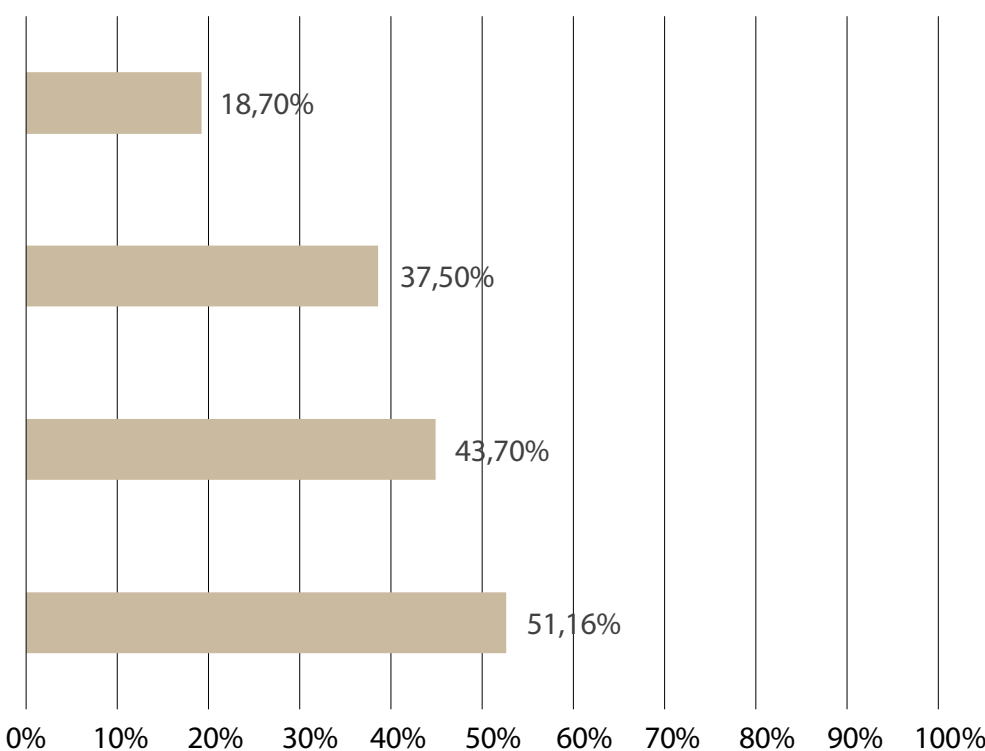

Tỷ lệ các tỉnh có nội dung này (\%)

Hình 13. Kiến nghị của địa phương về phát triển lâm nghiệp giai đoạn tới 

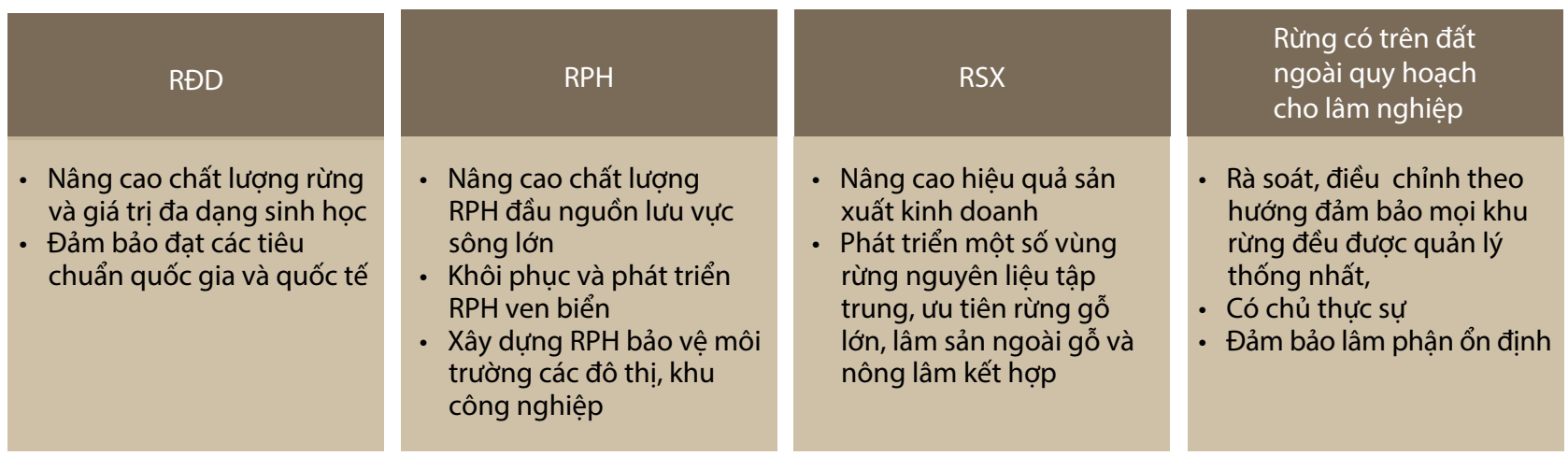

Hình 14. Định hướng quy hoạch phát triển các loại rừng

ranh giới trên bản đồ và trên thực địa; cấp Giấy chứng nhận quyền sử dụng đất lâm nghiệp; bảo đảm rừng có chủ thực sự và xác định rõ quyền và lợi ích lâu dài của người sử dụng đất và các chủ rừng, hướng tới ổn định lâm phận quốc gia; phát huy tiềm năng, lợi thế của rừng, xây dựng các chính sách tạo nguồn thu cho bảo vệ, phát triển rừng như chi trả DVMTR, nhất là trong bối cảnh $\mathrm{B} Đ K H$ ngày càng nghiêm trọng hơn.

\section{Khuyến khích sự tham gia của các thành phân} kinh tế. Nhu cầu nguyên liệu gỗ lớn cho công nghiệp chế biến là rất lớn, trong khi phát triển rừng kinh doanh gỗ lớn đòi hỏi các điêu kiện khắt khe như đất đai và loài cây phù hợp, nhu câu vốn dài ngày, kỹ thuật phức tạp,và quá trình tham gia quyết định có sự tham gia đây đủ của các bên. Cần có các giải pháp đặc thù phù hợp thực tế và đủ hấp dẫn để khuyến khích các thành phần kinh tế tham gia đầu tư vào lĩnh vực này.

\section{Đầu tư vào Khoa học và công nghệ. $\mathrm{KH} \& \mathrm{CN}$} đã góp phần quan trọng vào tăng trưởng ngành, nhất là nâng cao hiệu quả kinh tế RT bằng các loại giống có năng suất, chất lượng cao, lựa chọn cơ cấu cây trông và kỹ thuật thâm canh phù hợp. Cần đẩy mạnh việc nghiên cứu, ứng dụng $\mathrm{KH} \& \mathrm{CN}$, nhất là công nghệ cao trong sản xuất lâm nghiệp, ưu tiên các lĩnh vực như: giống, lâm sinh, giám sát tài nguyên rừng, quản lý sâu bệnh hại và cháy rừng; phát huy vai trò của $K H \& C N$ như một nhân tố quan trọng trong nâng cao năng suất, hiệu quả sản xuất kinh doanh lâm nghiệp. Cần hỗ trợ và đầu tư nghiên cứu và ứng dụng $\mathrm{KH} \& \mathrm{CN}$ nhằm phát huy các tiềm năng, lợi thế và sử dụng hiệu quả tài nguyên rừng; đổi mới cơ chế, chính sách nhằm khuyến khích các thành phân kinh tế tham gia nghiên cứu khoa học và ứng dụng công nghệ tiên tiến, thân thiện môi trường; hỗ trợ đổi mới sáng tạo và phát triển nguôn nhân lực chất lượng cao để sản xuất sản phẩm mới, có giá trị gia tăng cao, tiết kiệm nguyên liệu, mang thương hiệu Việt và phát triển sản xuất hàng hóa theo chuỗi giá trị.

\section{Mở rộng thị trường và phát triển lâm nghiệp} bền vững theo cơ chế thị trường và hội nhập quốc tế. Vận dụng sáng tạo cơ chế kinh tế thị trường để tổ chức thực hiện chiến lược, mở rộng thị trường, tích cực tham gia các hiệp định thương mại và chủ động hội nhập quốc tế ngày càng sâu, rộng; Nhất quán định hướng phát triển phù hợp với xu thế toàn cầu về phát triển bên vững, tăng trưởng xanh và ứng phó với $\mathrm{B} Đ K H$ là rất quan trọng để tạo sự đồng thuận và huy động các nguồn lực xã hội và cộng đông quốc tế tham gia phát triển lâm nghiệp. Phát triển lâm nghiệp bền vững theo cơ chế thị trường và hội nhập quốc tế; đẩy mạnh xã hội hóa và tổ chức liên kết sản xuất, kinh doanh theo chuỗi giá trị lâm sản; thu hút các nguôn lực và bảo đảm sự tham gia của các thành phân kinh tế trong hoạt động lâm nghiệp trên nguyên tắc thị trường đóng vai trò chủ yếu trong huy động, phân bổ và sử dụng các nguồn lực sản xuất, nhất là đất đai và tài nguyên rừng; chủ động tham gia chuỗi cung ứng toàn câu, phát huy các lợi thế và tận dụng các cơ hội để phát triển; hài hoà các chuẩn mực quốc tế và phát triển thương hiệu Việt; thực thi đây đủ các cam kết quốc tế về bảo tôn thiên nhiên, đa dạng sinh học, bảo vệ môi trường và ứng phó với $\mathrm{B} Đ \mathrm{KH}$, các quy định về thương mại lâm sản, phấn đấu trở thành một trong những nước hàng đầu thế giới về sản xuất, chế biến, xuất khẩu sản phẩm gỗ và lâm sản, góp phân nâng cao vai trò vị thế quốc gia trên trường quốc tế. Nhà nước đâu tư phát triển $R P H, R Đ D$ và đẩy mạnh xây dựng cơ sở hạ tâng lâm nghiệp để thu hút và hỗ trợ các thành phần kinh tế tham gia phát triển rừng. 
Nâng cao đa dạng sinh học. Bảo vệ, phục hôi $\mathrm{RTN}$ và quản lý $\mathrm{RTN}$ theo các phương án QLRBV gắn với bảo tôn ĐDSH và các DVMTR; hạn chế tối đa chuyển mục đích sử dụng RTN sang mục đích khác ngoài lâm nghiệp; khai thác hợp lý các diện tích đất rừng chưa sử dụng, hoặc đang sử dụng kém hiệu quả; hoàn thành việc giao đất, giao rừng, cho thuê rừng gắn với cấp giấy chứng nhận quyền sử dụng đất lâm nghiệp, bảo đảm tất cả diện tích rừng và đất lâm nghiệp phải được giao, cho thuê đến những chủ rừng thực sự thuộc mọi thành phân kinh tế; đảm bảo đủ các điều kiện để tổ chức quản lý bảo vệ rừng và phát triển bền vững tài nguyên rừng. Đẩy mạnh QLRBV gắn kết giữa bảo tôn và phát triển với sự tham gia tích cực của các bên liên quan như Nhà nước, khu vực tư nhân, chủ rừng trong quản lý rừng; đây mạnh CCR; tiếp tục hoàn thiện các chính sách và hướng dẫn kỹ thuật về $Q L R B V$ và CCR, có những chính sách cụ thể về quyền sở hữu hoặc sử dụng đất và về chính sách thuế; có hướng dẫn riêng cho các nhóm đối tượng có tính đặc thù khác nhau như cá nhân, hộ, nhóm hộ, cộng đồng. Tăng cường nâng cao năng lực cho các bên liên quan về QLRBV và CCR. Lồng ghép và xây dựng các chính sách và hướng dẫn liên quan đến thích ứng dựa trên hệ sinh thái (EBAs). Hiện nay có rất nhiều thảo luận liên quan đến việc phân loại rừng. Tuy nhiên, việc phân loại rừng chủ yếu dựa vào mục tiêu quản lí và hiệu quả của công tác bảo vệ và phát triển rừng, bảo tôn đa dạng sinh học không phụ thuộc vào việc đặt tên phân loại rừng là gì mà các biện pháp để đạt được mục tiêu bảo tôn và phát triển rừng. Gộp hai loại rừng phòng hộ và rừng đặc dụng vào một phân hạng sẽ không giúp Việt Nam đạt được mục tiêu Aichi 11 (về mở rộng diện tích bảo tôn). Với quỹ đất lâm nghiệp hiện có, khả năng mở rộng diện tích rừng đặc dụng là không cao. Các diện tích còn lại có thể bổ sung vào hệ thống rừng đặc dụng (hoặc các hệ thống khu bảo tồn trên cạn khác) nhỏ lẻ, có lẽ chỉ thêm được một vài khu Bảo tôn Loài và Sinh cảnh có diện tích nhỏ. Có ý kiến cho rằng việc xác định các Khu Đa dạng Sinh học Trọng yếu (KBAKey Biodiversity Area) có thể giúp cho việc mở rộng hệ thống khu bảo vệ. Điều này đúng về mặt nguyên tắc, KBA là công cụ tốt để xác định các điểm nóng vê đa dạng sinh học. Tuy nhiên, với quỹ đất hiện có, việc mở rộng diện tích rừng đặc dụng ra toàn bộ các KBA là không khả thi. KBA sẽ là một công cụ quan trọng và phù hợp hơn với việc giúp xác định (về mặt địa lý) các nơi cần ưu tiên đầu tư bảo tôn. Rừng phòng hộ của Việt
Nam không phải khu bảo vệ (protected areas) hoặc khu bảo tôn (conserved areas), do vậy việc gộp hai loại rừng này không giúp tăng diện tích được bảo tồn như yêu cầu của Aichi 11. Để tăng diện tích đáp ứng Aichi 11, Việt Nam cần đưa ra khuôn khổ pháp lý đề thừa nhận và báo cáo các $\mathrm{OECM}$ (trong đó có thể có nhiêuu diện tích rừng phòng hộ, và thậm chí cả rừng sản xuất). Ngoài ra OECM có thể giúp nhận diện và báo cáo kết quả bảo tồn ở các khu vực không phải đất lâm nghiệp, ví dụ như các khu đất tư nhân, hoặc các khu quân sự v.v... Việc cải thiện các kết quả bảo tôn đa dạng sinh học trong ngành lâm nghiệp sẽ phụ thuộc vào 2 việc: a) củng cố hệ thống rừng đặc dụng, chú trọng đâu tư vào các mục tiêu và hoạt động bảo tôn đa dạng sinh học, và b) cải thiện công tác bảo tôn đa dạng sinh học ngoài hệ thống rừng đặc dụng (rừng phòng hộ và sản xuất). Để nâng cao hiệu quả và hàm lượng bảo tôn đa dạng sinh học rừng, Chiến lược Phát triển Ngành Lâm nghiệp mới nên yêu câu:

- Xác định các khu rừng phòng hộ hiện còn có các giá trị bảo tôn và có khả năng đóng góp cho mục tiêu bảo tôn đa dạng sinh học. Giúp các khu đưa ra mục tiêu quản lý về khía cạnh này.

- Xác định rõ các mục tiêu bảo tồn đa dạng sinh học ở các cấp độ khác nhau: toàn ngành, cấp tỉnh, và cấp khu v.v... với các yêu cầu giám sát và báo cáo cụ thể đối với hiện trạng và diễn biến của các cấu thành đa dạng sinh học chính (loài, sinh cảnh, hệ sinh thái v.v...). Yêu cầu này nên là bắt buộc với tất cả các khu $R Đ D$ và một số khu rừng phòng hộ và sản xuất có giá trị và mục tiêu bảo tồn đa dạng sinh học.

- Áp dụng việc đánh giá các khu RĐD theo tiêu chuẩn quốc tế vể hiệu quả quản trị và quản lý khu bảo vệ và bảo tôn. Hiện tại, Chương trình Danh lục Xanh của IUCN đã đưa ra một bộ tiêu chuẩn toàn cầu, có thể áp dụng ở cấp độ địa phương phù hợp với các khu $\mathrm{R} Đ D$ và một số khu rừng phòng hộ trong việc đánh giá và theo dõi về quản trị, thiết kế và lập kế hoạch, hiệu quả quản lý và kết quả bảo tồn (IUCN 2020) (Việt Nam đã tham gia chương trình này và các hướng dẫn liên quan đều đã có bằng tiếng Việt). Danh lục Xanh cũng đã được CBD chấp thuận và yêu cầu các Bên Tham gia Công ước (trong đó có Việt Nam) sử dụng.

- Phân bổ nguôn kinh phí cho các hoạt động bảo tôn đa dạng sinh học, đặc biệt là cho giám sát, báo cáo về đa dạng sinh học tại các khu RĐD và phòng hộ. Kinh phí cho các hành động bảo tôn loài bao gồm cả bảo tôn in-situ 
và bảo tôn ex-situ như nghiên cứu, nhân nuôi, tái thả cũng cân được đưa vào chiến lược đầu tư của ngành lâm nghiệp.

- Rà soát, bổ sung và tổ chức thực hiện các đê án, chương trình hiện có như Đề án tăng cường năng lực quản lý hệ thống khu bảo tồn đến năm 2025, tầm nhìn đến năm 2030; Đề án "Bảo vệ và phát triển rừng ven biển ứng phó với biến đổi khí hậu giai đoạn 2021-2025, tầm nhìn đến 2030 ; Đê án Bảo tôn, khai thác và phát triển nguôn gen cây lâm nghiệp; Quy hoạch Bảo tôn đa dạng sinh học quốc gia thời kỳ 2021-2030, tầm nhìn đến năm 2050; Đê án Bảo tôn, khai thác và phát triển nguồn gen cây lâm nghiệp.

- Nâng cao năng lực hệ thống RĐD, RPH cơ sở hạ tầng kỹ thuật, trang thiết bị BVR và theo dõi, giám sát tài nguyên rừng; năng lực hệ thống Ban quản lý RPH, RĐD đáp ứng yêu cầu nhiệm vụ QLRBV bảo tồn tài nguyên ĐDSH và nguôn gen cây rừng, hài hòa với tiêu chuẩn quốc tế.

Phát triển rừng bền vững cả trên thực hiện quy hoạch hiệu quả và khai thác sử dụng rù̀ng bền vững. Trên cơ sở rà soát quy hoạch sử dụng đất, giải quyết triệt để việc tranh chấp đất đai, quy hoạch các vùng nguyên liệu tập trung, ưu tiên trông rừng gỗ lớn, bảo đảm phát triển ổn định 3 loại rừng; Đẩy mạnh xã hội hóa đâu tư vào phát triển rừng thông qua hệ thống chính sách khuyến khích về đất đai, tín dụng, thuế, thị trường,... đối với các chủ rù̀ng và các nhà đầu tư thuộc các thành phần kinh tế khác nhau. Nâng cao năng suất, chất lượng và hiệu quả RT sản xuất theo hướng tối ưu hóa hệ thống sản xuất và chuỗi giá trị lâm sản thông qua việc đẩy mạnh ứng dụng $\mathrm{KHCN}$, bao gôm: xác định cơ cấu cây trồng, loài cây trồng phù hợp điều kiện đất đai, khí hậu, có giá trị kinh tế cao và phù hợp mục đích kinh doanh và công nghệ khai thác, chế biến; áp dụng các tiến bộ kỹ thuật từ việc sử dụng giống chất lượng cao, trồng rừng thâm canh, cơ giới hóa và công nghệ cao trong các khâu sản xuất. Cần hạn chế khai thác gỗ non từ RT ít tuổi, đang sinh trưởng mạnh; tăng cường trồng rừng gỗ lớn; khai thác hợp lý $R P H$ là $R T$ vừa đảm bảo chức năng phòng hộ, vừa cung cấp gỗ cho chế biến; khoanh nuôi, cải tạo và làm giâu $R T N$ là $R S X$ nhằm nâng cao chất lượng để tạo nguôn cung cấp gỗ lớn sau năm 2030. Phát huy tối đa các dịch vụ hệ sinh thái rừng như hấp thụ và lưu giữ các-bon và các dịch vụ mới khác. Khuyến khích các tổ chức, hộ gia đình, tư nhân và cộng đông dân cư đâu tư, quản lý, khai thác, sử dụng rừng theo phương án QLRBV, được cấp CCR. Cân đầy mạnh cây trông, sử dụng LSNG, tập trung vào các nhóm sản phẩm có thế mạnh như mây tre, dược liệu, dầu nhựa, thực phẩm; Có cơ chế cho các chủ rừng được quản lý, khai thác và sử dụng hợp pháp LSNG. Ngoài ra, cần tiếp tục các Đê án, dự án đang triển khai thực hiện như Đề án bảo vệ, khôi phục và phát triển rừng bền vững vùng Tây Nguyên giai đoạn 2016-2030 (Quyết định số 297/ QĐ-TTg ngày 18/3/2019); Đê án QLRBV\&CCR (Quyết định số 1288/QĐ-TTg ngày 01/10/2018); Đê án $B V$, khôi phục và $P T R B V$ vùng Tây Bắc giai đoạn 2021-2030; Đề án "BV\&PTR ven biển ứng phó với $\mathrm{BĐKH} \mathrm{giai} \mathrm{đoạn} \mathrm{2021-2025,} \mathrm{tầm}$ nhìn đến 2030 . Cần xây dựng và thực hiện một số Đề án, dự án mới như Đê án phát triển giống cây lâm nghiệp giai đoạn 2021-2030; Đề án phát triển vùng nguyên liệu tập trung gắn với CNCB\&TMLS ( quyết định số $1717 / \mathrm{Q} Đ-B N N-$ TLCN ngày 14/5/2019 ban hành kế hoạch thực thi chỉ thị số 08/CT-TTg ngày 28/3/2019), Đê án phát triển lâm sản ngoài gỗ; Đề án phát triển các dịch vụ hệ sinh thái rừng; Đề án phát triển trồng rừng gỗ lớn, chuyển hóa $\mathrm{RTg}$ ỗ nhỏ sang gỗ lớn; đề án hỗ trợ hỗ gia đình tham gia hiệu quả chương trình chứng chỉ rừng.

\section{Đẩy mạnh phát triển công nghiệp chế biến và} thương mại lâm sản. Cần xây dựng Việt Nam thành một trong những trung tâm sản xuất, CB\&TMLS hàng đầu của thế giới thông qua việc thúc đẩy hình thành được những tập đoàn, khu công nghiệp lớn mang tầm cỡ khu vực và toàn câu, đủ năng lực về công nghệ, quản trị và thương hiệu để tham gia chuỗi giá trị toàn cầu; phát triển thương mại hiện đại, thương mại trực tuyến cùng với xây dựng thương hiệu Việt. Phát triển các Khu công nghiệp CBLS công nghệ cao, các cụm công nghiệp ngành gỗ tại những nơi thuận lợi về nguyên liệu, cơ sở hạ tâng; Đổi mới công nghệ; Phát triển công nghiệp phụ trợ; Tập trung phát triển các sản phẩm có ưu thế cạnh tranh cao và bền vững. Phát triển công nghiệp CBLS gắn với cơ cấu lại ngành lâm nghiệp theo hướng sản xuất hàng hóa lớn, hiện đại, thông minh, hiệu quả, nâng cao giá trị gia tăng, an toàn và bền vững; khuyến khích các thành phân kinh tế và đẩy mạnh hợp tác quốc tế trong đầu tư phát triển công nghiệp CB\&TMLS. Phát triển các mặt hàng có giá trị gia tăng cao; Tăng tỷ trọng các sản phẩm chế biến sâu; Nâng cao chất lượng, đa dạng hóa mẫu mã sản phẩm chế biến cho phù hợp với thị hiếu khách hàng trong và ngoài nước; 
xây dựng thương hiệu Việt và sử dụng nguồn gỗ hợp pháp, được cấp chứng chỉ QLRBV cho các mặt hàng xuất khẩu. Hạn chế dần việc xuất khẩu dăm gỗ. Mở rộng thị trường để đảm bảo phát triển ổn định, bền vững; chú ý các thị trường lớn như Mỹ, Liên minh châu Âu và Nhật Bản, Trung Quốc, Hàn Quốc, Úc.... Tổ chức tốt việc nhập khẩu nguyên liệu gỗ, lâm sản, hạn chế nhập khẩu sản phẩm đồ gỗ nội thất mà doanh nghiệp Việt có thể sản xuất được. Thực hiện hiệu quả FLEGT cũng sẽ đóng góp vào mục tiêu này.

Phát triển lâm nghiệp theo vùng lãnh thổ. Gắn mục tiêu, nhiệm vụ phát phát triển lâm nghiệp theo vùng lãnh thổ với quy hoạch phát triển lâm nghiệp quốc gia giai đoạn 2021-2030 để bảo đảm tính thống nhất, đồng bộ và khả thi đối với các mục tiêu chung của quốc gia cũng như mỗi vùng lãnh thổ. Phát huy lợi thế so sánh các vùng miền về điều kiện đất đai, khí hậu, tài nguyên rừng; chú trọng các đặc điểm đặc thù về cơ sở hạ tầng, văn hóa, xã hội và trình độ phát triển; phát triển lâm nghiệp theo hướng nâng cao hiệu quả kinh tế tổng hợp trên cơ sở cơ cấu ngành hàng và mô hình tổ chức sản xuất phù hợp theo chuỗi giá trị tối ưu; phát triển một số vùng rừng nguyên liệu tập trung gắn với công nghiệp chế biến; ưu tiên phát triển rừng gỗ lớn, lâm sản ngoài gỗ và nông lâm kết hợp. Đối với vùng Miền núi Phía Bắc và Tây Nguyên, cần đặc biệt quan tâm nhiệm vụ bảo vệ, khôi phục và phát triển rừng theo hướng bền vững, bên cạnh nâng cao chất lượng rừng hiện có cần tiếp tục nâng cao tỷ lệ che phủ của rừng đến mức có thể, nhằm bảo đảm yêu cầu phòng hộ đầu nguôn và bảo tồn ĐDSH của các vùng này cũng như cả nước. Đối với vùng Miền núi Phía Bắc cần xem xét việc điều chỉnh phạm vi lãnh thổ để phù hợp với phân vùng và quy hoạch chung của quốc gia.

\section{Phát triển Lâm nghiệp đô thị và trồng rừng} cảnh quan. Phát triển lâm nghiệp đô thị là một xu thế quốc tế và các quốc gia trong khu vực và trên toàn câu đều lông ghép lĩnh vực này trong các chiến lược lâm nghiệp từ năm 2020 trở đi. Ngoài ra, xây dựng cảnh quan môi trường xanh sạch - đẹp - an toàn là một tiêu chí trong xây dựng nông thôn mới (Quyết định 1980/QĐ-TTg ngày 17/10/2016 của Thủ tướng Chính phủ ban hành Bộ tiêu chí nông thôn mới 2016-2020). Trông cây xanh, đường giao thông, kênh, rạch,.. vừa cải thiện cảnh quan môi trường vừa góp phân giải quyết nhu câu gỗ cho sinh hoạt người dân và nguyên liệu cho chế biến lâm sản. Cần có cơ chế và chính sách Xây dựng và tổ chức thực hiện chương trình phát triển LNĐT sử dụng hiệu quả diện tích dành cho cây xanh trong quy hoạch các đô thị, khu công nghiệp, cụm dân cư, các tuyến giao thông, kênh rạch,.. để trông cây xanh với cơ cấu hợp lý, kỹ thuật tiên tiến, hiện đại, bảo đảm yêu cầu văn hóa cảnh quan, thẩm mỹ, bảo vệ môi trường và giá trị kinh tế. Cần có chính sách và cơ chế tài chính nhằm cải tạo, nâng cấp các khu rừng hiện có $(\mathrm{RPH}, \mathrm{DD}, \mathrm{SX})$ và phát triển các đai xanh xung quanh thành phố, khu dân cư,.. thành các khu rừng bảo vệ cung cấp các dịch vụ chất lượng cao đáp ửng yêu câu BVMT, nghỉ dưỡng phục hôi sức khỏe và giải trí, và các nhu cầu ngày càng cao của cư dân đô thị và phát triển trông cây phân tán trong nhân dân, nâng cao quy mô, chất lượng, hiệu quả Tết trông cây; huy động các nguôn lực theo hướng xã hội hóa.

Hoàn thiện, Đổi mới thể chế, chính sách, lập kế hoạch và giám sát ngành. Việt Nam hội nhập quốc tế ngày càng sâu, rộng; sự thay đổi nhanh chóng, của thế giới đòi hỏi sự thay đổi chính sách quốc gia, trong đó có chính sách lâm nghiệp. Luật Lâm nghiêp 2017 cần được tiếp tục hướng dẫn thực hiện, hài hòa với các Luật khác liên quan và các quy định quốc tế (ví dụ quyên carbon, lợi ích phi carbon, cam kết tự nguyện quốc gia, CITES, CBD, các biện pháp đảm bảo an toàn, Hiệp định Đối tác Tự nguyện (VPA) thông qua Thỏa thuận Tự do Thương mại cũng như Kế hoạch Hành động Thực thi Luật Lâm nghiệp, Quản trị Rừng và thương mại Lâm sản (FLEGT) theo sáng kiến của Liên minh Châu Âu). Các luật lệ thị trường và hình thái thương mại quốc tế mới cũng mang đến những thách thức đáng kể cho Việt Nam, đặc biệt khi ngành lâm nghiệp trong nước, vẫn còn được vận hành bởi nhiêu Doanh nghiệp nhà nước, chưa đáp ứng được các yêu câu mới này. Thêm vào đó, từ chính sách tới thực hiện trong thực tế còn là khoảng cách lớn, trong khi thực thi pháp luật còn gặp nhiều trở ngại đặc biệt về cơ chia sẻ lợi ích, đảm bảo các biện pháp an toàn, tiếp cận thị trường phát thải và thị trường carbon, huy động nguồn vốn và giám sát hiệu quả thực thi pháp luật và đánh giá hiệu quả của chính sách. Có thể thấy những nỗ lực của chính phủ và cộng đông quốc tế trong việc đề ra các chính sách về lâm nghiệp đã tạo điều kiện cho các bên tham gia vào quá trình chính sách nhiều hơn trước đây. Các tài liệu xây dựng chính sách đã ghi nhận rằng cần phải đẩy mạnh sự tham gia các tổ chức xã hội dân sự ( $\mathrm{CSO})$ và các nhóm dân tộc thiểu số vào quá trình đưa ra quyết định. 
Ngoài ra, cũng như nhiều quốc gia khác, giải quyết các nguyên nhân của mất rừng và suy thoái rừng là một thách thức lớn cho Việt Nam, nhất là khi việc giải quyết những nguyên nhân này gắn liên với phát triển kinh tế. Cần xây dựng các cơ chế chính sách phối hợp liên ngành để giải quyết được vấn đề này. Xây dựng hệ thống giám sát và đánh giá với phân bổ nguồn lực con người và tài chính phù hợp cũng điều kiện quan trọng để đảm bảo hiệu quả thực hiện chính sách.

Nâng cao công tác tuyên truyền, giáo dục nâng cao nhận thức của toàn xã hội về vai trò và tầm quan trọng của rừng đối với sự phát triển bền vững, bảo đảm an ninh quốc phòng và an ninh môi trường của đất nước; về giá trị ĐDSH và ý nghĩa bảo tồn các nguồn gen quý hiếm; thay đổi tập quán sử dụng các sản phẩm có nguôn gốc từ động, thực vật hoang dã; nâng cao nhận thức của các ngành, các cấp và người dân về quyền lợi, nghĩa vụ và trách nhiệm xã hội của các bên liên quan đối với công tác bảo vệ rừng, trong bối cảnh hội nhập quốc tế và ứng phó với biến đổi khí hậu. Công tác nâng cao tuyên truyên, giáo dục và nâng cao nhận thức xã hội phụ thuộc rất nhiều vào các chương trình và năng lực truyền thông của báo chí. Tuy nhiên, Phạm (2011) đã chỉ ra rằng năng lực, cách tiếp cận về các vấn để biến đổi khí hậu và vai trò của rừng trong bối cảnh này còn rất hạn chế. Trong khi đó các bên tham gia phỏng vấn cho rằng các cán bộ chuyên môn của ngành lâm nghiệp chửa thực sự có kĩ năng truyền thông tốt để có thể truyền tải nội dung về ngành lâm nghiệp hiệu quả do vậy nhận thức của các ngành khác và của công chúng về ngành rất hạn chế. Đào tạo bổ sung cho các nhà báo về vai trò của rừng trong biến đổi khí hậu, phối hợp và chia sẻ kiến thức tốt hơn giữa các bên liên quan sẽ là yếu tố quan trọng nhất giúp cải thiện lượng thông tin đăng tải về ngành lâm nghiệp trên các phương tiện thông tin đại chúng. Ngoài ra cần đa dạng hóa hình thức đào tạo; khuyến khích doanh nghiệp và các chủ rừng tham gia nghiên cứu; liên kết giữa nghiên cứu, đào tạo với khuyến lâm. 


\section{Tài liệu tham khảo}

[Bộ NN-PTNT, FSSP] Bộ Nông nghiệp và phát triển nông thôn, Đối tác hỗ trợ ngành Lâm nghiệp. 2010. Báo cáo tiến độ ngành Lâm nghiẹpp 2006-2020. Hà Nội: Bộ NN\&PTNT.

[Bộ NN-PTNT] Bộ Nông nghiệp và phát triển nông thôn, Tổng cục Lâm nghiệp 2011. Lâm nghiệt Việt Nam trong thập kỷ đâu của Thế kỷ $X X I$. Hà Nội, Việt Nam: NXB Nông nghiệp.

[Bộ NN-PTNT] Bộ Nông nghiệp và phát triển nông thôn. 2020. Báo cáo Hội nghị bàn giải pháp khôi phục chế biến, xuất khẩu gỗ và lâm sản ngày 15/5/2020. Hà Nội, Việt Nam: Bộ NN\&PTNT.

Chính phủ Việt Nam. 2011. Báo cáo số 128/BCCP ngày 9/8/2011 của Chính phủ về Tổng kết thực hiện Dự án "Trông mới 5 triệu ha rừng" và Kế hoạch bảo vệ, phát triển rừng giai đoạn 2011-2020. Hà Nội: Quốc hội.

Chính phủ Việt Nam. 2017. Báo cáo số 435/BC$\mathrm{CP}$ ngày 13/10/2017 của Chinh phủ về việc tổ chức thực hiện Kế hoạch bảo vệ và phát triển rừng giai đoạn 2011-2020 theo cơ chế Chương trình mục tiêu quốc gia. Hà Nội: Quốc hội.

Chính phủ Việt Nam. 2019. Báo cáo số 476/BC$\mathrm{CP}$ ngày 11.10.2019 về tình hình thực hiện Kế hoạch bảo vệ và phát triển rừng giai đoạn 2011-2020 theo cơ chế Chương trình mục tiêu quốc gia. Hà Nội: Quốc hội.

Dự án Trường sơn xanh. 2020. Báo cáo sơ bộ đánh giá hiện trạng ngành chế biến gỗ tại Việt Nam, 2020. Dự Ân Trường Sơn Xanh. Việt Nam.

Đoàn D. 1998. Giao đất lâm nghiệp và lợi ích trong việc trông rüng. Báo cáo tại hội thảo về 'Chủ rüng và lợi ích trong kinh doanh rüng'. Hà Nội, Việt Nam: Bộ NN\&PTNT.

GIZ. 2019. Báo cáo công tác quản lý hệ thống và RĐD, PH năm 2019 và giải pháp phát triên bền vüng. Hà Nội, Việt Nam: GIZ.

Helvetas Vietnam. 2002. Kinh nghiệm và tiêm năng đóng góp của Việt Nam vào muc tiêu phát triên của cơ quan hợp tác phát triên
Thuy Sỹ: Môi trường sống bền vũng và giảm nghèo ở vùng cao. Hà Nội, Việt Nam: Helvetas Vietnam.

Hoàng LS. 2020. Đánh giá kết quả thực hiện Chương trinh chế biến và thương mại lâm sản. Báo cáo tư vấn của TCLN. Hà Nội, Việt Nam: Tổng cục Lâm nghiệp.

IUCN. 2020. IUCN Green List of Protected and Conserved Areas. Có tại https://www.iucn. org/theme/protected-areas/our-work/iucngreen-list-protected-and-conserved-areas, truy cập 29/10/2020

Le KC. 2010. Báo cáo đánh giá tiến độ chuiongtrinh lâm nghiệp quốc gia Việt Nam (Dử thảo lân 2). Có tại: http:// vietnamforestry.org.vn/NewsFolder/ NFPAssessmentReport_EN.pdf [2/22012].

Le ND, Loft L, Tjajadi JS, Pham TT and Wong GY. 2016. Being equitable is not always fair: An assessment of PFES implementation in Dien Bien, Vietnam. Working Paper 205. Bogor, Indonesia: CIFOR.

Moeliono M, Pham TT, Le ND, Brockhaus M, Wong G, Kallio M and Nguyen DT. 2016. Local Givernance, Social Networks and REDD+: Lessons from Swidden Communities in Vietnam. Human Ecologu 44(4): 435-448. Bogor Barat, Indonesia: CIFOR.

Nguyễn BN. 2019. Lâm nghiệp Việt Nam thời kỳ đổi mới (1986-2018). Báo cáo tư vấn IC.2019-03-02. Hà Nội, Việt Nam: UNDP.

Nguyễn QT, Nguyễn $B N$ và Nguyễn NT 2008. Cải cách vấn đề chiếm dụng rừng ở Việt Nam: Nghiên cứu tình hình tạivùng núi phía Bắc và Tây Nguyên. Hà Nội, Việt Nam: Trung tâm vì con người và rừng (RECOFTC) và tổ chức Sáng kiến vì Tài nguyên và Quyền lợi (RRI).

Pham TT, Campbell BM, Garnett ST, Aslin H and Hoang MH. 2010. Importance and impacts of intermediary boundary organizations in facilitating payment for environmental services in Vietnam. Environmental Conservation 37: 64-72. Bogor Barat, Indonesia: CIFOR. 
Pham TT, Garnet ST and Aslin HJ. 2011. Organisational and Institutional Opportunities and Constraints for Poor Households to Participate in Payment for Environmental Service Schemes in Vietnam. The Asia Pacific Journal Of Public Administration 33(1): 57-76. Bogor Barat, Indonesia: CIFOR.

Phạm TT. 2011. Vấn đề chính sách REDD+ được thể hiện trong thông tin đại chúng: Nghiên cứu điêm tại Việt Nam. Báo cáo Nghiên cứu Số 83. Bogor, Indonesia: CIFOR.

Phạm TT, Moeliono $M$, Nguyễn TH, Nguyễn HT và Vũ TH. 2012. Bối cảnh REDD+ ở Việt Nam. Nguyên nhân, đối tượng và thể chế. Báo cáo chuyên đề 77. Bogor Barat, Indonesia: CIFOR

Phạm TT, Bennett K, Vũ TP, Brunner J, Lê ND và Nguyễn ĐT. 2013. Chi trả dịch vụ môi trường rüng tại Việt Nam: Tü chính sách đến thực tiễn. Báo cáo chuyên đề 98. Bogor Barat, Indonesia: CIFOR.

Pham TT and Brockhaus M. 2015. Gender mainstreaming in REDD+ and PES - Lessons learned from Vietnam. Gender Climat Brief 5. Bogor Barat, Indonesia: CIFOR.

Pham TT, Le ND, Vu TP, Nguyen HT and Nguyen VT. 2016a. Forest land allocation and payments for forest environmental services in four northwestern provinces of Vietnam: From policy to practice. Occasional Paper 155. Bogor, Indonesia: CIFOR.

Pham TT, Mai YH, Moeliono M and Brockhaus M. 2016b. Women's participation in REDD+ national decision-making in Vietnam. International Forestry Review 20(10). Bogo Barat, Indonesia: CIFOR.

Phạm TT, Vũ TP, Vũ TH, Lương TT, Lê ND và Đào TLC. 2017. Cơ hội và thách thức cho dịnh giá rüng ở Việt Nam - Góc nhìn của các bên liên quan. Báo cáo chuyên đê 191. Bogor, Indonesia: CIFOR.

Phạm TT, Bùi TMN, Phạm HL, Nguyễn VD, Đào TLC và Hoàng TL. 2018a. Tiềm năng của REDD+ trong đóng góp tài chính cho ngành lâm nghiẹpp ở Viẹt Nam. Info Brief no 232. Bogor Barat, Indonesia: CIFOR.

Phạm TT, Bùi TMN, Phạm HL, Nguyễn VD, Đào TLC, Hoàng TL. 2018b. Vai trò của chi trả dịch vu môi trường rǜng trong hỗ trợ tài chính cho ngành lâm nghiệp Việt Nam. Info brief no 228. Bogor Barat, Indonesia: CIFOR.

Phạm TT, Đào TLC, Hoàng TL, Bùi TMN, Phạm HL và Nguyễn VD. 2018c. Cơ hội và thách thức trong huy động tài chính thực hiện Chiến lược phát triển lâm nghiệp Việt Nam giai đoạn 2006-2020. Occasional Paper 191. Bogor, Indonesia: CIFOR

Phạm TT, Đào TLC, Hoàng TL, Nguyễn ĐT, Lê MT, Nông HH và Đặng TN. 2018d. Tác động của chi trả dịch vu môi trường rüng (PFES) tại Sơn La, Việt Nam: tù giả thuyết đến thực tế. Nghiên cứu chuyên đề 188. Bogor, Indonesia: CIFOR.

Phạm TT, Ngô HC và Nông NKN. 2019. 10 Xu thế lâm nghiệp trên thế giới Việt Nam cân xem xét trong quá trình xây dựng Chiến lược phát triển lâm nghiệp giai đoạn 2020-2030. Báo cáo chuyên đê 256. Bogor, Indonesia: CIFOR

Phạm TT, Hoàng TL, Nguyễn ĐT, Lê $H N$, và Stibniati A. 2019a. Nguôn tài chính cho bảo vệ và phát triên rüng ngập mặn tại cấp cơ sở: Bài học tù tỉnh Bến Tre, Trà Vinh và Cà Mau, Việt Nam. Info Brief no 251. Bogor Barat, Indonesia: CIFOR.

Phạm TT, Nguyễn ĐT, Đào TLC và Hoàng TL. 2019b. Chuân bị cho Việt Nam săn sàng với luật chơi mới trên thị trường quốc tế - sản xuất và kinh doanh không liên quan tới phá rüng và suy thoái rüng. Báo cáo chuyên đê 253. Bogor, Indonesia: CIFOR.

Pham TT, Vu TP, Pham DC, Dao LHT, Nguyen VT, Hoang NVH, Hoang TL, Dao TLC and Nguyen DT. 2019c. Opportunities and challenges for mangrove management in Vietnam: Lessons learned from Thai Binh, Quang Ninh and Thanh Hoa provinces. Occasional Paper 197. Bogor, Indonesia: CIFOR.

Phạm TT và Lê TTT. 2020. Lông ghép Các-bon xanh vào Đóng góp do Quốc gia tự quyết dịnh tại 13 quốc gia Châu Á - Thái Bình Dương: Hiện trạng, cơ hội và thách thúc. Info brief no 275. Bogor Barat, Indonesia: CIFOR.

Phạm TT, Đào TLC, Hoàng TL, Ngô HC, Hoàng TU, Trần NMH, Hoàng MH, Nguyễn VD. $2020 \mathrm{a}$. Uu tiên đầu tư và quan tâm của các bên đối với lĩnh vực các hoạt động bảo vệ và phát triển rừng tại Việt Nam giai đoạn 2011-2019. Bản tin tóm tắt của CIFOR số 44. Bogor Barat, Indonesia: CIFOR. DOI: 10.17528/cifor/007567

Phạm TT, Hoàng TL, Nguyễn DT, Đào TLC, Ngô $H C$ và $P$ hạm VH. 2020b. Bối cảnh cho REDD+ tại Việt Nam: Nguyên nhân, đối tượng và thể chế. Tái bản lần 2. Báo cáo chuyên đề 203. Bogor, Indonesia: CIFOR. 
Phạm TT, Ngô HC, Hoàng MH, Williams P, Hoàng TL và Đào TLC. 2020c. Chiến lược và chính sách phát triển lâm nghiệp thế giới. Báo cáo chuyên đề 262. Bogor Barat, Indonesia: CIFOR

Phương VT, Phạm TT, Lê ND và Đào TLC. 2017. Kinh nghiệm quốc tế và các đề xuất sủa đổi khung pháp lý về định giá rüng tại Việt Nam. Báo cáo chuyên đề 168. Bogor, Indonesia: CIFOR.

Tổng cục lâm nghiệp. 2020a. Lâm nghiệp Việt Nam 75 năm hình thành và phát triển (1945-2020). Hà Nội, Việt Nam: NXB Nông nghiệp.

Tổng cục Lâm nghiệp. 2020b. Kết quả thực hiện Chiến lược nghiên cứu lâm nghiệp Việt Nam giai đoạn 2008-2020 và đinh hướng nghiên cứu lâm nghiệp Việt Nam giai đoạn 20212030. Kỷ yếu Hội thảo Nghiên cứu khoa học và Chuyển giao công nghẹ Lâm nghiệp: Thành tự và Định hướng phát triển. Hà Nội, Việt Nam: NXB Nông nghiệp.

Trần ĐN. 2020. Đánh giá kết quả thực hiện Chương trình vê chính sách, thể chế, lập kế hoạch và giám sát ngành lâm nghiệp. Báo cáo tư vấn của TCLN. Hà Nội, Việt Nam: Tổng cục Lâm nghiệp.

Trân NT. 2000. Giao đất lâm nghiệp: tiền đê để quản lý rừng cộng đông. Báo cáo trình bày tại Hội thảo «Phát triển nông thôn bền vững ở khu vực miên núi Đông Nam Â". Hà Nội, Việt Nam: EC, SIDA, GTZ.

Trần TTH. 2020. Đánh giá kết quả thực hiện Chương trình nghiên cứu, giáo dục, đào tạo và khuyến lâm. Báo cáo tư vấn của TCLN. Hà Nội, Việt Nam: Tổng cục lâm nghiệp.

VIFA. 2019. Kết quả khảo sát của Tạp chí điện tử Bảo vệ rừng \& Môi trường của VIFA

Vũ TD. 2020. Báo cáo đánh giá Chương trình quản lý, phát triển rừng bền vững giai đoạn 2006-2020. Báo cáo tư vấn của Tổng cục Lâm nghiệp. Hà Nội, Việt Nam: NXB Nông nghiệp.

Yang AL, Pham TT, Dieu H, Wong G, Le ND, Tjajadi JS and Loft L. 2015. Lesson from the preception of equal uity and richs in payment for forest environmental services (FPES) fund distribution: a case study of Dien Bien and Son La pronvice in Vietnam. Bogor Barat, Indonesia: CIFOR. 


\section{Phụ lục}

\section{Danh mục văn bản chính sách, pháp luật Lâm nghiệp giai đoạn 2006-2020}

\begin{tabular}{|c|c|}
\hline TT & Nội dung \\
\hline 1 & Phát triển lâm nghiệp gắn với xóa đói giảm nghèo, hỗ trợ đồng bào dân tộc thiểu số \\
\hline 1 & $\begin{array}{l}\text { Nghị quyết số } 30 \mathrm{a} / 2008 / \mathrm{NQ}-\mathrm{CP} \text { ngày } 27 / 12 / 2008 \text { của Chính phủ về Chương trình hỗ trợ giảm nghèo } \\
\text { nhanh và bền vứng đối với } 61 \text { huyện nghèo }\end{array}$ \\
\hline 2 & $\begin{array}{l}\text { Nghị định số } 75 / 2015 / \mathrm{NE}-\mathrm{CP} \text { ngày 09/9/2015 của Chính phủ về chính sách bảo vệ và phát triển rừng gắn } \\
\text { với chính sách giảm nghèo bền vững và hỗ trợ đồng bào dân tộc }\end{array}$ \\
\hline 3 & $\begin{array}{l}\text { Quyết định số 2621/QĐ-TTg ngày 31/12/2013 của Thủ tướng Chính phủ về việc sửa đổi, bổ sung một số } \\
\text { định mức hố trợ phát triển sản xuất quy định tại Nghị quyết số 30a/2008/NQ-CP ngày 27/12/2008 của } \\
\text { Chính phủ }\end{array}$ \\
\hline 4 & $\begin{array}{l}\text { Thông tư liên tịch số 93/2016/TTLT-BTC-BNNPTNT ngày 27/6/2016 của Bộ Tài chính, Bộ NN-PTNT hướng } \\
\text { dẫn chế độ quản lý, sử dụng kinh phí sự nghiệp thực hiện Nghị định số 75/2015/NĐ-CP; }\end{array}$ \\
\hline II & Chính sách đầu tư phát triển rừng đặc dụng, phòng hộ \\
\hline 5 & $\begin{array}{l}\text { Nghị định số } 117 / 2010 / N Đ-C P \text { ngày } 24 \text { tháng } 12 \text { năm } 2010 \text { của Chính phủ về tổ chức quản lý hệ thống } \\
\text { rừng đặc dụng }\end{array}$ \\
\hline 6 & $\begin{array}{l}\text { Quyết định số 24/2012/QĐ-TTg ngày 01/6/2012 của Thủ tướng Chính phủ về chính sách đầu tư phát triển } \\
\text { rừng đặc dụng giai đoạn 2011-2020 }\end{array}$ \\
\hline 7 & $\begin{array}{l}\text { Quyết định số 17/2015/QĐ-TTg ngày 09/6/2015 của Thủ tướng Chính phủ ban hành Quy chế quản lý } \\
\text { rừng phòng hộ }\end{array}$ \\
\hline 8 & $\begin{array}{l}\text { Thông tư liên tịch số 100/2013/TTLT-BTC-BNNPTNT ngày 26/7/2013 của Bộ Tài chính, Bộ NN-PTNT hướng } \\
\text { dẫn thực hiện một số Điê̂u của Quyết định 24/2012/QĐ-TTg ngày 01/6/2012 của Thủ tướng Chính phủ về } \\
\text { chính sách đâuu tư phát triển rừng đặc dụng giai đoạn 2011-2020 }\end{array}$ \\
\hline
\end{tabular}

\section{Chính sách phát triển rừng sản xuất}

9 Nghị định số 119/2016/NĐ-CP ngày 23/8/2016 của Chính phủ về một số chính sách quản lý, bảo vệ và phát triển bền vững rừng ven biển ứng phó với biến đổi khí hậu

10 Quyết định số 38/2016/QĐ-TTg ngày 14/9/2016 của Thủ tướng Chính phủ về việc ban hành một số chính sách bảo vệ, phát triển rừng và đầu tư hỗ trợ kết cấu hạ thầng, giao nhiệm vụ công ích đối với các công ty nông, lâm nghiệp

11 Quyết định số 49/2016/QĐ-TTg ngày 01/11/2016 của Thủ tướng Chính phủ ban hành Quy chế quản lý rừng sản xuất

12 Chỉ thị số 02/CT-TTg ngày 24/01/2014 của Thủ tướng Chính phủ về việc tăng cường chỉ đạo thực hiện trồng rừng thay thế diện tích rừng chuyển sang mục đích khác

13 Thông tư số 23/2013/TT-BNNPTNT ngày 04/5/2013 của Bộ N-PTNT quy định về cải tạo rừng tự nhiên nghèo kiệt là rừng sản xuất

14 Thông tư số 24/2013/TT-BNNPTNT ngày 06/5/2013 của Bộ NN-PTNT quy định về trồng rừng thay thế khi chuyển mục đích sử dụng rừng sang mục đích khác

15 Thông tư số 26/2015/TT-BNNPTNT ngày 29/07/2015 của Bộ NN-PTNT sửa đổi, bổ sung một số điều của Thông tư số 24/2013/TT-BNNPTNT ngày 06/5/2013 của Bộ Nn-PTNT quy định về trồng rừng thay thế khi chuyển mục đích sử dụng rừng sang mục đích khác 


\begin{tabular}{|c|c|}
\hline TT & Nội dung \\
\hline IV & Chính sách chi trả dịch vụ môi trường rừng \\
\hline 16 & $\begin{array}{l}\text { Nghị định số 99/2010/NĐ-CP ngày } 24 \text { tháng } 9 \text { năm } 2010 \text { của Chính phủ về chính sách chi trả dịch vụ môi } \\
\text { trường rừng }\end{array}$ \\
\hline 17 & $\begin{array}{l}\text { Nghị định số 147/2016/NĐ-CP ngày 02/11/2016 của Chính phủ về sửa đổi, bổ sung một số điều của Nghị } \\
\text { định số 99/2010/NĐ-CP ngày 24/9/2010 của Chính phủ về chính sách chi trả dịch vụ môi trường rừng }\end{array}$ \\
\hline 18 & $\begin{array}{l}\text { Thông tư liên tịch số 62/2012/TTLT-BNNPTNT-BTC ngày 16/11/012 của Bộ NN-PTNT - Bộ Tài chính hướng } \\
\text { dẫn quản lý sừ dụng tiền chi trả dịch vụ môi trường rừng. }\end{array}$ \\
\hline
\end{tabular}

V Chính sách quản lý bảo vệ rừng

19 Chỉ thị số 13-CT/TW ngày 12/01/2017 của Ban Bí thư về tăng cường sự lãnh đạo của Đảng đối với công tác quản lý, bảo vệ và phát triển rừng

20 Nghị định số 157/2013/NĐ-CP ngày 11/11/2013 của Chính phủ quy định xử phạt vi phạm hành chính về quản lý rừng, phát triển rừng, bảo vệ rừng và quản lý lâm sản;

21 Nghị định số 40/2015/NĐ-CP ngày 27/4/2015 của Chính phủ sửa đổi, bổ sung một số điều Nghị định số 157/2013/NĐ-CP ngày 11/11/2013 của Chính phủ quy định xử phạt vi phạm hành chính về quản lý rừng, phát triển rừng, bảo vệ rừng và quản lý lâm sản

22 Nghị định số 168/2016/NĐ-CP ngày 27/12/2016 của Chính phủ quy định về khoán rừng, vườn cây và diện tích mặt nước trong các Ban quản lý rừng đặc dụng, rừng phòng hộ và Công ty TNHH MTV Nông, lâm nghiệp Nhà nước

23 Quyết định số 07/2012/QĐ-TTg ngày 08/02/2012 của Thủ tướng Chính phủ ban hành một số chính sách tăng cường công tác bảo vệ rừng

24 Quyết định số 44/2016/QĐ-TTg ngày 19/10/2016 của Thủ tướng Chính phủ Quyết định về lực lượng bảo vệ rừng chuyên trách của chủ rừng

25 Chỉ thị số 1685/2011/CT-TTg ngày 27/9/2011 của Thủ tướng Chính phủ về việc Tăng cường chỉ đạo thực hiện các biện pháp bảo vệ rừng, ngăn chặn tình trạng phá rừng và chống người thi hành công vụ

VI Chính sách khuyến khích đầu tư vào Lâm nghiệp

26 Nghị định số 210/2013/NĐ-CP ngày 19/12/2013 của Chính phủ về chính sách khuyến khích doanh nghiệp đầu tư vào nông nghiệp, nông thôn

27 Nghị định số 57/2018/NĐ-CP ngày 17/4/2018 của Chính phủ về cơ chế, chính sách khuyến khích doanh nghiệp đầu tư vào nông nghiệp, nông thôn

28 Nghị định số 55/2015/NĐ-CP ngày 09/6/2015 của Chính phủ về chính sách tín dụng phục vụ phát triển nông nghiệp, nông thôn

29 Nghị định số 02/2017/NĐ-CP về cơ chế, chính sách hỗ trợ sản xuất nông nghiệp để khôi phục sản xuất vùng bị thiệt hại do thiên tai, dịch bệnh; trong đó có cả lĩnh vực lâm nghiệp

\section{Chính sách đổi mới công ty nông lâm nghiệp.}

30 Nghị quyết số 30-NQ/TW ngày 12/3/2014 của Bộ Chính trị BCH Trung ương Đảng Cộng sản Việt Nam về tiếp tục sắp xếp, đổi mới và phát triển, nâng cao hiệu quả hoạt động của công ty nông, lâm nghiệp

31 Nghị định số 118/2014/NĐ-CP ngày 17/12/2014 của Chính phủ về sắp xếp, đổi mới và phát triển, nâng cao hiệu quả hoạt động của công ty nông, lâm nghiệp

32 Thông tư số 02/2015/TT-BNNPTNT ngày 27/01/2015 của Bộ NN-PTNT hướng dẫn xây dựng đề án và phương án tổng thể sắp xếp, đổi mới công ty nông, lâm nghiệp theo Nghị định số 118/2014/NĐ-CP ngày 17/12/2014 của Chính phủ về sắp xếp, đổi mới và phát triển, nâng cao hiệu quả hoạt động của công ty nông, lâm nghiệp

\section{Chính sách quản lý rừng tự nhiên}

33 Quyết định số 2242/QĐ-TTg ngày 11/12/2014 của Thủ tướng Chính phủ phê duyệt Đề án Tăng cường công tác quản lý khai thác gỗ rừng tự nhiên giai đoạn 2014-2020

34 Thông tư số 24/2016/TT-BNNPTNT ngày 30/6/2016 của Bộ NN-PTNT ban hành danh mục và công bố mã HS đối với hàng hóa cấm xuất khẩu là gỗ tròn, gỗ xẻ các loại từ gỗ rừng tự nhiên trong nước và hàng hóa xuất khẩu theo giấy phép là củi, than làm từ gỗ hoặc củi có nguồn gốc từ gỗ rừng tự nhiên trong nước 


\begin{tabular}{ll}
\hline TT & Nội dung \\
\hline 35 & $\begin{array}{l}\text { Thông tư số 330/2016/TT-BTC hướng dẫn lập dự toán, cấp phát, thanh toán, quyết toán kinh phí hỗ trợ } \\
\text { từ ngân sách nhà nước để bảo vệ diện tích rừng tự nhiên của các công ty lâm nghiệp phải tạm dừng khai } \\
\text { thác theo Quyết định số 2242/QĐ-TTg ngày 11/12/2014 của Thư tướng chính phủ }\end{array}$ \\
\hline IX & $\begin{array}{l}\text { Chính sách bảo tồn đa dạng sinh học } \\
36\end{array}$ \\
$\begin{array}{l}\text { Thông tư số 90/2008/TT-BNN ngày 28/8/2008 của Bộ NN-PTNT hướng dẫn xử lý tang vật là động vật rừng } \\
\text { sau xứ lý tịch thu }\end{array}$ \\
37 & Quyết định số 95/2008/OĐ-BNN ngày 29/9/2008 của Bộ Nông nghiệp và PTNT về việc ban hành Quy chế
\end{tabular}
quản lý gấu nuôi

38 Nghị định số 06/2019/NĐ-CP của chính phủ về về quản lý thực vật rừng, động vật rừng nguy cấp, quý, hiếm và thực thi công ước về buôn bán quốc tế các loài động vật, thực vật hoang dã nguy cấp (thay thế Nghị định 95/2008/QĐ-BNN)

39 Nghị định số 99/2009/NĐ-CP của Chính phủ về xử phạt vi phạm hành chính trong lĩnh vực quản lý rừng, bảo vệ rừng và quản lý lâm sản

40 Nghị định số 35/2019/ND-CP về quy định xử phạt vi phạm hành chính trong lĩnh vực lâm nghiệp (thay thế Nghị định 99/2009/NĐ-CP)

41 Thông tư số 59/2010/TT-BNNPTNT ngày 19/10/2010 của Bộ NN-PTNT ban hành Danh mục các loài động vật, thực vật hoang dã thuộc quản lý của Công ước về buôn bán quốc tế các loài động vật, thực vật hoang dã nguy cấp (CITES)

42 Thông tư số 04/2017/TT-BNNPTNT về việc ban hành danh mục các loài động vật, thực vật hoang dã quy định trong các phụ lục của công ước về buôn bán quốc tế các loài động vật, thực vật hoang dã nguy cấp (thay Thông tư số 59/2010/TT-BNNPTNT)

43 Thông tư số 35/2011/TT-BNN ngày 20/5/2011 của Bộ Nông nghiệp và PTNT đã ban hành hướng dẫn thực hiện khai thác, tận thu gỗ và lâm sản ngoài gỗ

44 Thông tư Số 27/2018/TT-BNNPTNT quy định về quản lý, truy xuất nguồn gốc lâm sản (thay thế Thông tư 35/2011/TT-BNN)

45 Quyết định số 11/2011/QĐ-TTg ngày 18/02/2011 của Thủ tướng Chính phủ về chính sách khuyến khích phát triển ngành mây tre

46 Thông tư số 01/2012/TT-BNN ngày 04/01/2012 của Bộ NN-PTNT quy định hồ sơ lâm sản hợp pháp và kiểm tra nguồn gốc lâm sản

47 Thông tư số 42/2012/TT-BNNPTNT ngày 21/8/2012 của Bộ NN-PTNT sửa đổi, bổ sung một số điều của Thông tư số 01/2012/TT-BNNPTNT quy định hồ sơ lâm sản hợp pháp và kiểm tra nguồn gốc lâm sản

48 Thông tư số 47/2012/TT-BNNPTNT ngày 25/9/2012 Quy định về quản lý khai thác từ tự nhiên và nuôi động vật rừng thông thường

49 Thông tư Số 27/2018/TT-BNPTNT quy định về quản lý, truy xuất nguồn gốc lâm sản (thay thế Thông tư 47/2012/TT-BNNPTNT)

50 Quyết định số 39/2012/QĐ-TTg ngày 05/10/2012 của Thủ tướng Chính phủ về Quy chế quản lý cây cảnh, cây bóng mát, cây cổ thụ

51 Quyết định số 11/2013/QĐ-TTg ngày 24/01/2013 của Thủ tướng Chính phủ về cấm xuất khẩu, nhập khẩu, mua bán mẫu vật một số loài động vật hoang dã thuộc các Phụ lục của Công ước về buôn bán quốc tế các loài động vật, thực vật hoang dã nguy cấp

52 Quyết định số 176/QĐ-TTg ngày 30/10/2013 của Thủ tướng Chính phủ về việc phê duyệt Quy hoạch tổng thể phát triển dược liệu đến năm 2020 và định hướng đến năm 2030

53 Nghị định số 65/2017/NĐ-CP ngày 19/5/2017 của Chính phủ ban hành chính sách đặc thù về giống, vốn và công nghệ trong phát triển nuôi trồng, khai thác dược liệu

\section{Lĩnh vực khác}

54 Thông tư liên tịch số 07/2011/TTLT-BNNPTNT-BTNMT ngày 29/01/2011 của Bộ N-PTNT - Bộ Tài nguyên và Môi trường hướng dẫn một số nội dung về giao rừng, thuê rừng gắn liền với giao đất, thuê đất lâm nghiệp

55 Thông tư số 172/2011/TT-BTC ngày 01/12/2011 của Bộ Tài chính quy định về quản lý, thanh toán, quyết toán vốn đầu tư xây dựng công trình lâm sinh thuộc nguồn vốn ngân sách nhà nước 


\begin{tabular}{|c|c|}
\hline TT & Nội dung \\
\hline 56 & $\begin{array}{l}\text { Thông tư số 51/2012/TT-BNN ngày 19/10/2012 của Bộ NN-PTNT hướng dẫn thực hiện nhiệm vụ bảo vệ và } \\
\text { phát triển rừng quy định tại Quyết định số 57/QĐ-TTg ngày 09/01/2012 của Thủ tướng Chính phủ }\end{array}$ \\
\hline 57 & $\begin{array}{l}\text { Thông tư số } 18 / 2013 / \mathrm{TT}-\mathrm{BTC} \text { ngày } 20 / 02 / 2013 \text { của Bộ Tài chính hướng dẫn trình tự thủ tục thanh lý rừng } \\
\text { trồng và quản lý, sử dụng số tiền thu được từ thanh lý rừng trồng không thành rừng, rừng trồng không } \\
\text { có khả năng thành rừng }\end{array}$ \\
\hline 58 & $\begin{array}{l}\text { Thông tư liên tịch số 10/2013/TTLT-BNNPTNT-BTC ngày 01/02/2013 của Bộ NN-PTNT, Bộ Tài chính hướng } \\
\text { dẫn quản lý, sứ dụng vốn đầu tư từ ngân sách nhà nước thực hiện Kế hoạch B\&PTR giai đoạn 2011-2020 } \\
\text { theo Quyết định số 57/QĐ-TTg ngày 09/01/2012 của Thư tướng Chính phủ }\end{array}$ \\
\hline 59 & $\begin{array}{l}\text { Thông tư liên tịch số 80/2013/TTLT-BTC-BNN ngày 14/6/2013 của Bộ Tài chính, Bộ NN-PTNT hướng dẫn } \\
\text { chế độ quản lý, sử dụng kinh phí sự nghiệp thực hiện bảo vệ và phát triển rừng }\end{array}$ \\
\hline 60 & $\begin{array}{l}\text { Thông tư liên tịch số 20/2013/TTLT-BNNPTNT-BTC ngày 27/3/2013 của Bộ NN-PTNT, Bộ Tài chính sưa đổi, } \\
\text { bổ sung một số điều tại Thông tư Liên tịch số 61/2007/TTLT-BNN-BTC ngày 22/6/2007 của Liên Bộ NN- } \\
\text { PTNT - Tài chính hướng dẫn chế độ quân lý, sử dụng kinh phí ngân sách Nhà nước cấp cho hoạt động cơ } \\
\text { quan Kiểm lâm các cấp; thanh toán chi phí cho các tổ chức, cá nhân được huy động để ngăn chặn tình } \\
\text { trạng chặt phá rừng trái pháp luật và phòng cháy, chữa cháy rừng }\end{array}$ \\
\hline 61 & $\begin{array}{l}\text { Thông tư số 38/2014/TT-BNNPTNT ngày 03/11/2014 của Bộ NN-PTNT hướng dẫn về phương án quản lý } \\
\text { rừng bền vững }\end{array}$ \\
\hline 62 & $\begin{array}{l}\text { Thông tư số 40/2015/TT-BNNPTNT ngày 21/10/2015 về việc sửa đổi, bổ sung một số điều của Thông tư } \\
\text { số 01/2012/TT-BNNPTNT ngày 04/01/2012 của Bộ NN-PTNT quy định hổ sơ lâm sản hợp pháp và kiểm tra } \\
\text { nguồn gốc lâm sản }\end{array}$ \\
\hline 63 & $\begin{array}{l}\text { Thông tư số 44/2015/TT-BNNPTNT ngày 23/11/2015 của Bộ NN-PTNT ban hành Danh mục giống cây } \\
\text { trồng lâm nghiệp chính }\end{array}$ \\
\hline 64 & $\begin{array}{l}\text { Thông tư số } 21 / 2016 / T T-B N N P T N T \text { ngày 28/6/2016 của Bộ NN-PTNT quy định về khai thác chính và tận } \\
\text { dụng, tận thu lâm sản }\end{array}$ \\
\hline 65 & $\begin{array}{l}\text { Thông tư số 23/2016/TT-BNNPTNT ngày 30/6/2016 của Bộ NN-PTNT hướng dẫn một số nội dung quản lý } \\
\text { công trình lâm sinh }\end{array}$ \\
\hline
\end{tabular}

\section{Văn bản hướng dẫn thi hành Luật Lâm nghiệp}

66 Nghị định số 156/2018/NĐ-CP ngày 16/11/2018 của Chính phủ quy định chi tiết thi hành một số điều của Luật Lâm nghiệp

67 Nghị định số 01/2019/NĐ-CP ngày 01/01/2019 của Chính phủ về Kiểm lâm và Lực lượng chuyên trách bảo vệ rừng của chủ rừng

68 Nghị định số 06/2019/NĐ-CP ngày 22/01/2019 của Chính phủ về quản lý thực vật rừng, động vật rừng nguy cấp, quý, hiếm và thực thi Công ước về buôn bán quốc tế các loài động vật, thực vật hoang dã nguy cấp

69 Nghị định số 35/2019/NĐ-CP ngày 25/4/2019 của Chính phủ quy định xử phạt hành chính trong lĩnh vực Lâm nghiệp

70 Thông tư số 27/2018/TT-BNNPTNT ngày 16/11/2018 của Bộ Nông nghiệp và Phát triển nông thôn quy định về quản lý, truy xuất nguồn gốc lâm sản

71 Thông tư số 28/2018/TT-BNNPTNT ngày 16/11/2018 của Bộ Nông nghiệp và Phát triển nông thôn quy định về quản lý rừng bền vững

72 Thông tư số 29/2018/TT-BNNPTNT ngày 16/11/2018 của Bộ Nông nghiệp và Phát triển nông thôn quy định về các biện pháp lâm sinh

73 Thông tư số 30/2018/TT-BNNPTNT ngày 16/11/2018 của Bộ Nông nghiệp và Phát triển nông thôn quy định Danh mục loài cây trồng lâm nghiệp chính; công nhận giống và nguồn giống; quản lý vật liệu giống cây trồng lâm nghiệp chính

74 Thông tư số 31/2018/TT-BNNPTNT ngày 16/11/2018 của Bộ Nông nghiệp và Phát triển nông thôn quy định về phân định ranh giới rừng

75 Thông tư số 32/2018/TT-BNNPTNT ngày 16/11/2018 của Bộ Nông nghiệp và Phát triển nông thôn quy định phương pháp định giá rừng; khung giá rừng 


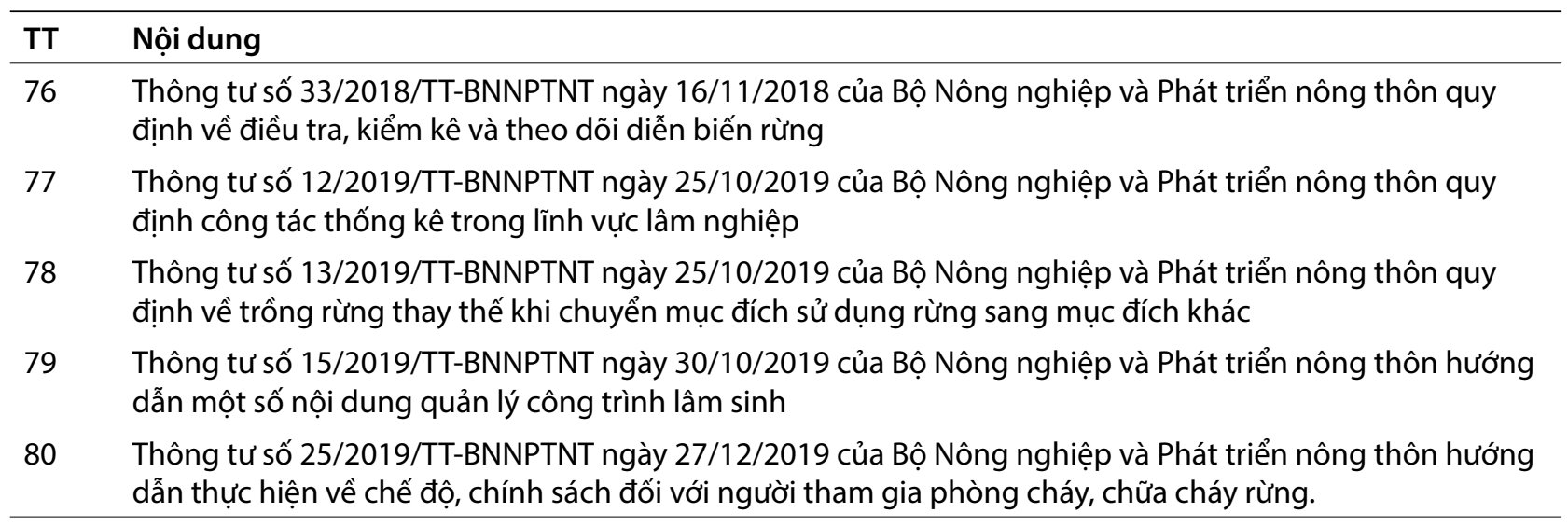



Các báo cáo chuyên đề của CIFOR chuyển giao các kết quả nghiên cứu quan trọng đối với ngành lâm nghiệp. Nội dung của báo cáo đều được đánh giá bởi các chuyên gia trong và ngoài tổ chức.

Chiến lược phát triển lâm nghiệp Việt Nam là một trong những chính sách định hướng quan trọng của ngành. Qua mỗi thời kì, định hướng, mục tiêu và giải pháp của chiến lược có thể khác nhau tùy vào mục tiêu và quan điểm chính trị cũng như định hướng vai trò của ngành lâm nghiệp trong tổng thể phát triển kinh tế xã hội chung của cả nước. Việc kế thừa các bài học kinh nghiệm, phát triển Chiến lược mới dựa trên nền tảng kinh nghiệm thu được từ việc giải quyết khó khăn và tận dụng các cơ hội luôn là ưu tiên hàng đầu của Chính phủ Việt Nam.

Chiến lược phát triển lâm nghiệp đầu tiên tổng thể của Việt Nam được ra đời vào năm 2006 đặt dấu mốc quan trọng cho việc chuyển đổi phát triển ngành lâm nghiệp theo hướng truyền thống vốn chỉ tập trung vào các giá trị trực tiếp của rừng sang cách tiếp cận mới bao gồm tiếp cận ngành, tiếp cận cảnh quan, tiếp cận theo chuỗi và tiếp cận theo dịch vụ môi trường và dịch vụ sinh thái rừng. Tuy nhiên, Chiến lược này sẽ kết thúc vào năm 2020 và Tổng cục Lâm nghiệp (VNFOREST), Bộ NN\&PTNT đang trong quá trình xây dựng Chiến lược phát triển lâm nghiệp giai đoạn 2021-2030 tầm nhìn 2050. Báo cáo này là kết quả hợp tác giữa Tổ chức Nghiên cứu Lâm nghiệp Quốc tế (CIFOR) và Tổng cục lâm nghiệp (VNFOREST) nhằm hỗ trợ thông tin đầu vào cho VNFOREST trong quá trình xây dựng Chiến lược mới. Báo cáo rà soát thành tựu và thách thức trong quá trình thực hiện Chiến lược phát triển lâm nghiệp 2006-2020 đồng thời đưa ra các kiến nghị để các nhà hoạch định chính sách xem xét trong quá trình xây dựng Chiến lược trong giai đoạn mới thông qua nghiên cứu tài liệu thứ cấp và phỏng vấn các bên có liên quan.

Kết quả nghiên cứu chỉ ra rằng, tính tới thời điểm 2020, Việt Nam đã vượt một số chỉ tiêu đề ra trong Chiến lược Phát triển lâm nghiệp Việt Nam giai đoạn 2006-2020 bao gồm: đẩy nhanh tốc độ tăng giá trị sản xuất ngành, nâng cao giá trị xuất khẩu sản phẩm gỗ và lâm sản, nâng cao sản lượng khai thác gỗ trong nước, trồng rừng phòng hộ, đặc dụng. Tuy nhiên, ngành lâm nghiệp còn gặp nhiều thách thức trong việc thực hiện một số chỉ tiêu quan trọng khác như: nâng cao diện tích rừng sản xuất (RSX) có chứng chỉ Quản lí rừng bền vững (QLRBV), nâng cao sản lượng gỗ lớn, nâng cao nguồn thu dịch vụ môi trường rừng (DVMTR), đảm bảo diện tích giao, cho thuê rừng và đất lâm nghiệp, giảm số hộ nghèo ở các vùng lâm nghiệp trọng điểm, và nâng cao tỷ lệ lao động lâm nghiệp được đào tạo. Mặc dù có một số chỉ tiêu đề ra trong chiến lược cũ không thể đạt được như dự kiến, nhưng so với một số mục tiêu phát triển ngành lại vượt trội, ví dụ như; tỷ lệ che phủ rừng, trồng lại rừng sau khi khai thác, giảm các vụ vi phạm về bảo vệ rừng, trồng cây phân tán. Các mục tiêu đã đạt được hoặc vượt mục tiêu đề ra là nhờ có sự cam kết chính trị mạnh mẽ của chính phủ, chính sách phù hợp với xu thế và thị trường, năng lực quản lí của trung ương và địa phương đã được cải thiện và sự hỗ trợ tích cực của các nhà tài trợ quốc tế, sự tham gia của các tổ chức dân sự và khối tư nhân. Việc chưa đạt được một số các chỉ tiêu là do khó khăn trong việc thực hiện chính sách đảm bảo hiệu quả, hiệu ích và công bằng tại cấp cơ sở đi kèm với thiếu hụt về nguồn lực, nguồn vốn, một số mục tiêu và chỉ tiêu tham vọng không thực tế trong bối cảnh kinh tế, chính trị, và thị trường. Để giải quyết các nguyên nhân này cần có cách tiếp cận mới và các giải pháp kinh tế, xã hội và kĩ thuật hiệu quả hơn. Việc xây dựng Chiến lược phát triển lâm nghiệp giai đoạn 2021-2030 tầm nhìn 2050 cần xem xét cả thành tựu lẫn thách thức trong quá trình thực hiện chính sách giai đoạn trước, đón đầu các xu thế toàn cầu và hài hóa hóa trong bối cảnh phát triển chính trị, kinh tế, xã hội của cả nước.

Định hướng phát triển của Chiến lược mới cũng cần phải xem xét trong bối cảnh hội nhập hóa với các yêu cầu quốc tế để tạo điều kiện cho việc huy động nguồn tài chính trong nước và ngoài nước giúp hiện đại hóa ngành, nâng cao vai trò và giá trị của ngành trong việc xóa đói giảm nghèo, phát triển kinh tế và cung cấp hệ sinh thái rừng bền vững.

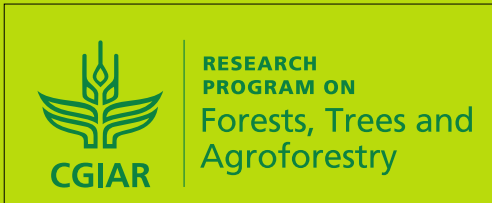

cifor.org
Chương trình nghiên cứu của CGIAR về Rừng, Cây gỗ và Nông lâm kết hợp (FTA) là chương trình phát triển nghiên cứu lớn nhất thế giới nhằm nâng cao vai trò của rừng, cây gỗ và nông lâm kết hợp với mục tiêu phát triển bền vững và đảm bảo lương thực để ứng phó với biến đổi khí hậu. CIFOR chủ trì các nghiên cứu FTA trong mối quan hệ đối tác chiến lược với Bioversity International, CATIE, CIRAD, INBAR, ICRAF và TBI. Nghiên cứu này được hỗ trợ bởi Quỹ đối tác CGIAR: cigar.org/funders/ nghiên cứu sáng tạo, nâng cao năng lực của các bên đối tác, tích cực tham gia đối thoại với các bên liên quan để hỗ trợ định hình chính sách và thực tiễn tác động tới rừng và con người. CIFOR là tổ chức nghiên cứu thuộc liên minh CGIAR và chủ trì các chương trình nghiên cứu của CGIAR về Rừng, Cây gỗ và Nông lâm kết hợp (FTA). Trụ sở chính của CIFOR đặt tại Bogor, Indonesia và các văn phòng của CIFOR có mặt tại Nairobi, Kenya; Yaounde, Cameroon; Lima, Peru và Bonn, Germany. 